\title{
Summary and Evaluation of Hydraulic Property Data Available for the Hanford Site Upper Basalt Confined Aquifer System
}

\author{
F. A. Spane, Jr. \\ V. R. Vermeul
}

September 1994

Prepared for

the U.S. Department of Energy

under Contract DE-AC06-76RLO 1830

Pacific Northwest Laboratory

Richland, Washington 99352

DISTRIBUTION OF THIS DOCUMENT IS UNLIMITED

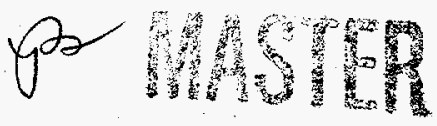





\section{DISCLAIMER}

This report was prepared as an account of work sponsored by an agency of the United States Government. Neither the United States Government nor any agency thereof, nor any of their employees, make any warranty, express or implied, or assumes any legal liability or responsibility for the accuracy, completeness, or usefulness of any information, apparatus, product, or process disclosed, or represents that its use would not infringe privately owned rights. Reference herein to any specific commercial product, process, or service by trade name, trademark, manufacturer, or otherwise does not necessarily constitute or imply its endorsement, recommendation, or favoring by the United States Government or any agency thereof. The views and opinions of authors expressed herein do not necessarily state or reflect those of the United States Government or any agency thereof. 


\section{DISCLAIMER}

Portions of this document may be illegible in electronic image products. Images are produced from the best available original document. 


\section{Summary}

Pacific Northwest Laboratory, ${ }^{(a)}$ as part of the Hanford Site Ground-Water Surveillance Project, examines the potential for offsite migration of contamination within the upper basalt confined aquifer system. For the past 40 years, hydrologic testing of the upper basalt confined aquifer has been conducted by a number of Hanford Site programs. Hydraulic property estimates obtained from the analysis of the hydrologic test results are important for evaluating aquifer flow characteristics (i.e., ground-water flow patterns, flow velocity, transport travel time).

This report presents the first comprehensive Hanford Site-wide summary of hydraulic properties for the upper basalt confined aquifer system (i.e., the upper Saddle Mountains Basalt). In completing the summary, available hydrologic test data were reevaluated using recently developed diagnostic test analysis methods (i.e., pressure derivative analysis) to ensure that the hydrologic analysis methods used were applicable for the test data examined. A comparison of calculated transmissivity estimates indicates that, for most test results, a general correspondence within a factor of two between reanalysis and previously reported test values was obtained. For a majority of the tests, previously reported values are greater than reanalysis estimates. This overestimation is attributed to a number of factors, including, in many cases, a misapplication of nonleaky confined aquifer analysis methods in previous analysis reports to tests that exhibit leaky confined aquifer response behavior.

Results of the test analyses indicate a similar range for transmissivity values for the various hydrogeologic units making up the upper basalt confined aquifer. Approximately $90 \%$ of the calculated transmissivity values for upper basalt confined aquifer hydrogeologic units occur within the range of $10^{0}$ to $10^{2} \mathrm{~m}^{2} / \mathrm{d}$, with $65 \%$ of the calculated estimate values occurring between $10^{1}$ to $10^{2} \mathrm{~m}^{2} / \mathrm{d}$. These summary findings are consistent with the general range of values previously reported for basalt interflow contact zones and sedimentary interbeds within the Saddle Mountains Basalt.

(a) Pacific Northwest Laboratory is operated for the U.S. Department of Energy by Battelle Memorial Institute. 


\section{Acknowledgments}

Several people contributed to the development of this report. In particular, important technical peer review comments were provided by $\mathrm{P}$. D. Thorne. In addition, the editorial review and guidance by B. V. Johnston and S. P. Luttrell and the report preparation support provided by C. L. Wimbish and W. D. Webber are also acknowledged. Special thanks are also extended to S. P. Reidel (Westinghouse Hanford Company) and R. L. Jackson (CH2M-Hill) for their efforts in recovering hydrologic test data originally obtained by Rockwell Hanford Operations. 



\section{Contents}

Summary $\ldots \ldots \ldots \ldots \ldots \ldots \ldots \ldots \ldots \ldots \ldots \ldots \ldots \ldots \ldots \ldots$

Acknowledgments $\ldots \ldots \ldots \ldots \ldots \ldots \ldots \ldots \ldots \ldots \ldots \ldots \ldots \ldots \ldots$

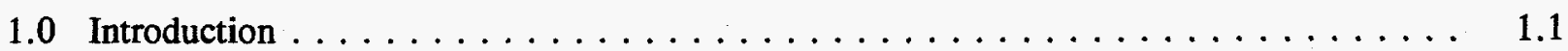

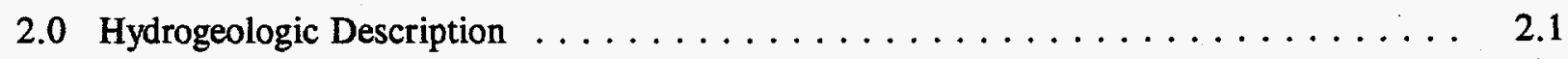

3.0 Data Availability $\ldots \ldots \ldots \ldots \ldots \ldots \ldots \ldots \ldots \ldots \ldots \ldots \ldots \ldots \ldots \ldots \ldots$

4.0 Test Analysis Method Description $\ldots \ldots \ldots \ldots \ldots \ldots \ldots \ldots \ldots \ldots \ldots \ldots$

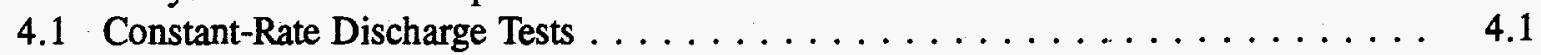

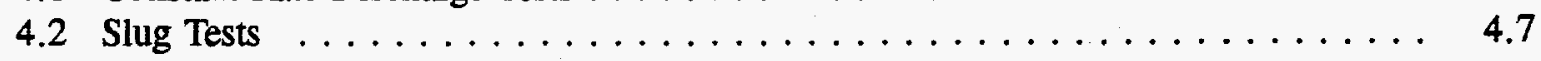

5.0 Hydraulic Test Result Summary $\ldots \ldots \ldots \ldots \ldots \ldots \ldots \ldots \ldots \ldots \ldots$

6.0 References $\ldots \ldots \ldots \ldots \ldots \ldots \ldots \ldots \ldots \ldots \ldots \ldots \ldots \ldots \ldots \ldots \ldots \ldots$

Appendix - Test Summaries. . . . . . . . . . . . . . . . . . A.1 


\section{Figures}

2.1 General Stratigraphic Relationships Within the Pasco Basin . . . . . . . . . . 2.2

2.2 Isopach Map of the Rattlesnake Ridge Interbed on the Hanford Site $\ldots \ldots \ldots \ldots$

3.1 Location of Upper Basalt Confined Aquifer Test Sites $\ldots \ldots \ldots \ldots \ldots . \ldots \ldots$

4.1 Dimensionless Pressure and Dimensionless Pressure Derivative Curves for Constant-Rate Discharge Tests in Nonleaky Confined Aquifers . . . . . . . . . . .

4.2 Diagnostic Log-Log Pressure and Pressure Derivative Plots for Various Hydrogeologic Formation/Boundary Conditions $\ldots \ldots \ldots \ldots \ldots \ldots \ldots$

4.3 Dimensionless Head and Dimensionless Head Derivative Type Curves for Nonleaky Confined Aquifer Slug Tests $\ldots \ldots \ldots \ldots \ldots \ldots \ldots \ldots \ldots$

5.1 Comparison of Reanalysis and Previously Reported Slug Test Transmissivity Estimates for Upper Basalt Confined Aquifer Test Intervals . . . . . . . . . . . . .

5.2 Comparison of Reanalysis and Previously Reported Constant-Rate Pumping Test Transmissivity Estimates for Upper Basalt Confined Aquifer Test Intervals . . . . . . . . .

5.3 Comparison of Reanalysis Slug and Constant-Rate Pumping Test Transmissivity . Estimates for Upper Basalt Confined Aquifer Test Intervals . . . . . . . . . . . . .

5.4 Distribution of Reanalysis Best Estimate Transmissivity Values for Individual Hydrogeologic Units Within the Upper Basalt Confined Aquifer . 


\subsection{Introduction}

As part of the Hanford Site Ground-Water Surveillance Project, Flow System Characterization Task, Pacific Northwest Laboratory examines the potential for off-site migration of contamination within the upper basalt confined aquifer system for U.S. Department of Energy (DOE). Included as part of this activity, hydrologic field tests are conducted within selected wells completed in the upper Saddle Mountains Basalt. Analysis of the field test data provides local estimates of hydraulic properties. When combined with areal head information, ground-water travel time and flow velocity within the upper basalt confined aquifer system can be estimated.

This report presents the first comprehensive Hanford Site-wide summary of hydraulic properties for the upper basalt confined aquifer system. In completing this summary, available hydrologic test data from 35 single-well test intervals were reevaluated. This evaluation used recently developed diagnostic pressure derivative test analysis methods (Bourdet et al. 1983, 1984, 1989) and computer analysis software (Spane and Wurstner 1993) to improve the hydrologic test analyses.

The report discusses the hydrogeologic characteristics (Section 2.0) and availability of hydrologic test data (Section 3.0) for the upper basalt confined aquifer system. A detailed description of the test methods used in reanalyzing the tests is also presented in Section 4.0. Results of the test reanalyses, together with estimate comparisons, are provided in Section 5.0. A table summarizing the test reanalysis results and individual abbreviated analysis summaries for each test interval are included in the accompanying appendix. 


\subsection{Hydrogeologic Description}

The upper basalt confined aquifer system refers collectively to pervious basalt interflow contacts and intercalated sedimentary interbeds that occur within the upper Saddle Mountains Basalt. Confinement to this aquifer system is provided by silt and clay units within the overlying suprabasalt sediments (i.e., Ringold Formation) and dense, low-permeability interior sections of the basalt flows (e.g., Elephant Mountain Member). Information presented previously by Gephart et al. (1979) and DOE $(1982,1988)$ indicates that confined aquifers within the Saddle Mountains Basalt commonly display a high degree of similarity with respect to hydrochemistry and hydraulic properties, with no obvious hydrostratigraphic divisions present. For the purpose of limiting the scope of this investigation, the lower boundary of the upper basalt confined aquifer system is arbitrarily placed immediately below the first laterally extensive hydrogeologic unit, which for the Hanford Site is the Rattlesnake Ridge interbed (Figure 2.1).

It should be noted that this aquifer system has been previously referred to as the upper confined aquifer. However, in limited areas of the Hanford Site, units of the lower Ringold Formation (which stratigraphically overlies the Saddle Mountains Basalt) can also be locally confined. Where this hydrologic condition occurs, the lower Ringold units have been grouped by some investigators with the underlying Saddle Mountains Basalt as part of the upper confined aquifer system. This report pertains solely to pervious hydrogeologic units within the upper Saddle Mountains Basalt that, for the purpose of avoiding confusion, are referred to collectively as the upper basalt confined aquifer system.

Within the Pasco Basin, the Rattlesnake Ridge interbed is the thickest and most widespread sedimentary unit that occurs intercalated within the upper Saddle Mountains Basalt. Stratigraphically, the interbed is assigned to the Ellensburg Formation and occurs at the boundary contact between the Elephant Mountain and Pomona Members (see Figure 2.1). The interbed varies in thickness from 0 to $33 \mathrm{~m}$. Figure 2.2 is an isopach map that displays the thickness distribution for the Rattlesnake Ridge interbed within the Pasco Basin. As indicated in Figure 2.2, the interbed is absent primarily in the area to the west of the Hanford Site and within the Hanford Site in the vicinity of the Gable Mountain Gable Butte structural area. As discussed in Spane and Raymond (1993), this absence in the area immediately north of the 200 East Area is of particular hydrogeologic importance.

Reidel and Fecht (1981) reported that areally the Rattlesnake Ridge interbed can be divided into three distinct facies based on lithology and texture:

- First Facies occurs primarily in the Cold Creek syncline area and consists of three units: 1) a lower clay or tuffaceous sandstone; 2) a middle, micaceous-arkosic and/or tuffaceous sandstone; and 3) an upper, tuffaceous siltstone or tuffaceous sandstone.

- Second Facies occurs in areas where the unit is relatively thin and consists of a single, tuffaceous sandstone to siltstone unit.

- Third Facies is limited to the northwest section of the Pasco Basin, similar in lithology and texture to first facies, but contains a conglomerate with plutonic and metamorphic clasts near its base. 


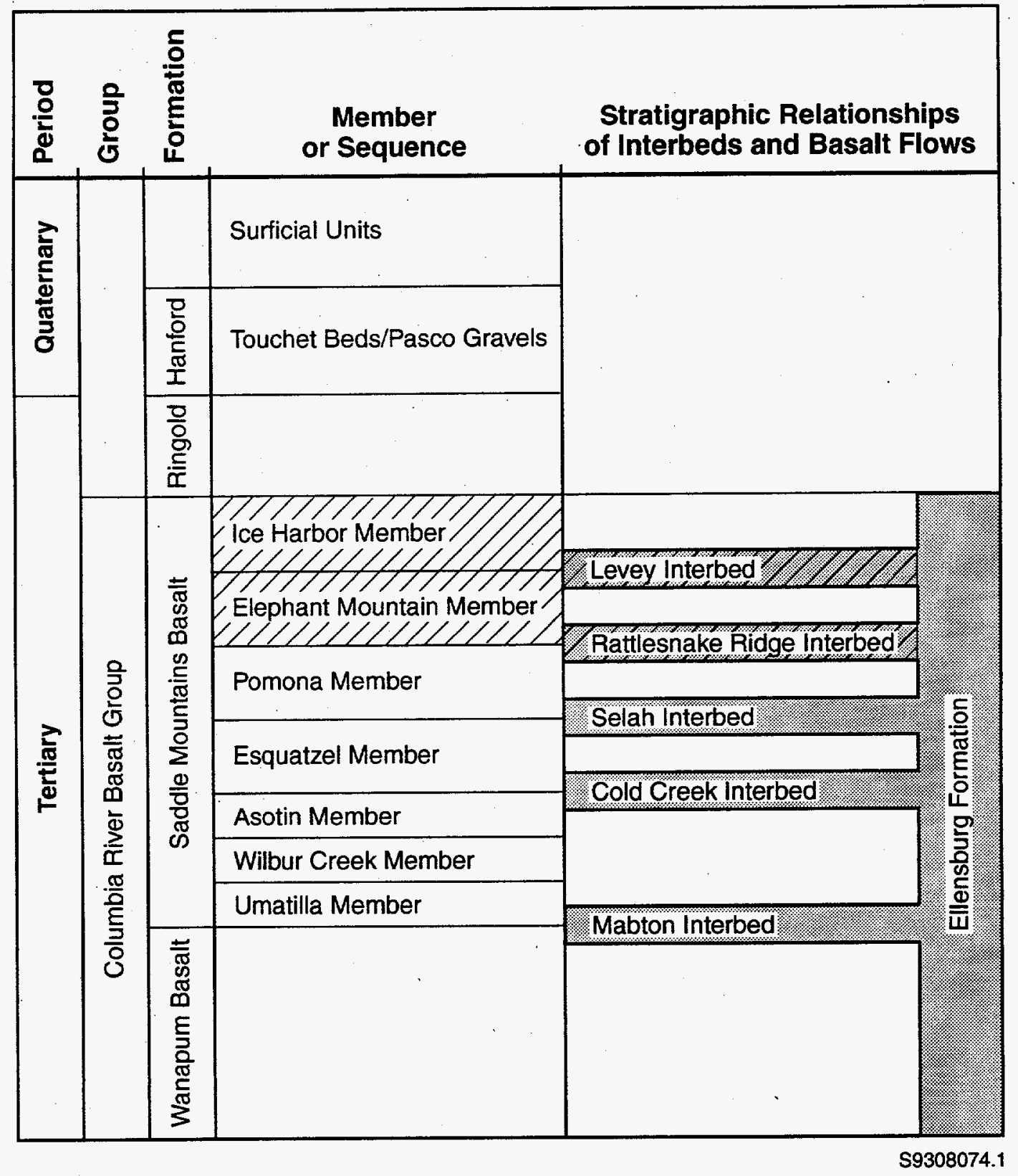

DU Upper Basalt Confined Aquifer System

Figure 2.1. General Stratigraphic Relationships Within the Pasco Basin 


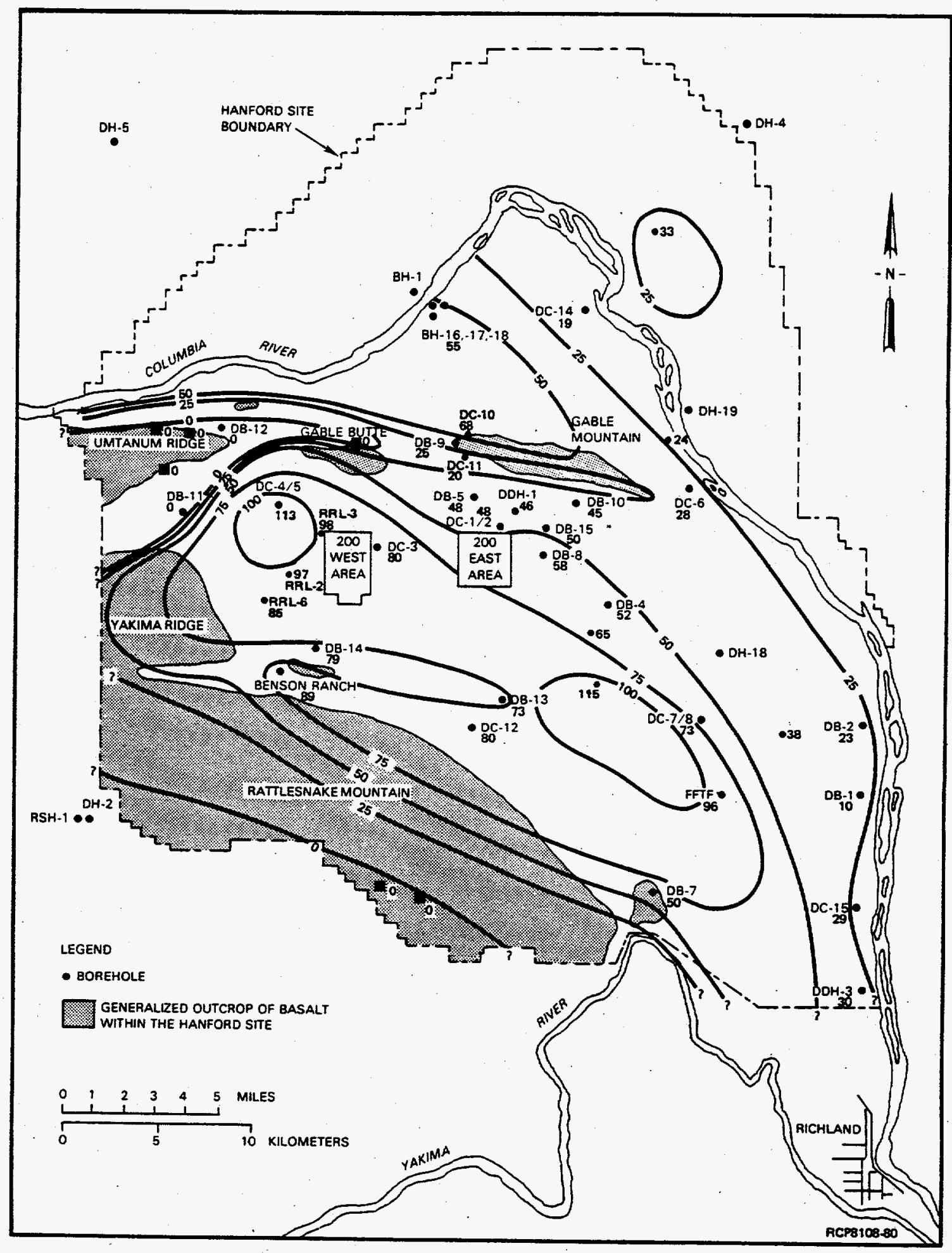

Figure 2.2. Isopach Map of the Rattlesnake Ridge Interbed on the Hanford Site (adapted from Reidel and Fecht 1981) 
Permeable sandstone units within the interbed are important hydrogeologically in the lateral transmission of ground water. Because of its areal extent, hydraulic properties, and thickness, the Rattlesnake Ridge interbed represents the most important hydrogeologic unit within the upper basalt confined aquifer system for the potential offsite migration of contamination.

Other locally important hydrogeologic units within the upper basalt confined aquifer system include the overlying Levey interbed, which occurs along the southern boundary of the Hanford Site, and a pervious interflow contact between two Elephant Mountain Member flows (i.e., the Elephant Mountain and Ward Gap flows), which occurs in the eastern half of the Hanford Site. Although not as areally extensive as the underlying Rattlesnake Ridge interbed, where these units occur, their hydraulic property characteristics warrant their inclusion in the upper basalt confined aquifer system. 


\subsection{Data Availability}

In developing this hydraulic property summary report, test data from 35 single-well test intervals were evaluated. The Rattlesnake Ridge interbed $(n=22)$ has the highest number of test intervals represented, while the Levey interbed $(n=2)$ has the fewest. A total of seven test intervals were also available for interflow contacts within the Elephant Mountain Member. Four of the test intervals have composite hydrogeologic unit completions. Hydraulic test data available for the test intervals were primarily limited to slug tests $(n=18$; total tests $=36)$ and constant-rate discharge tests $(n=35$; total tests $=43$ ). Only 18 of the 35 test intervals have both slug and constant-rate discharge test data.

Test data evaluated in this report represent the results obtained from a variety of past and current Hanford Site programs. The following programs contributed test data reviewed in this report:

- Long-Term Transuranic Defense Waste - Offsite Migration Program (Rockwell Hanford Operations)

- Basalt Waste Isolation Project (Rockwell Hanford Operations)

- Ground-Water Surveillance Project, Hanford Site Flow System Characterization Task (Pacific Northwest Laboratory)

- Various Hanford Site CERCLA (Comprehensive Environmental Response, Compensation, and Liability Act) and RCRA (Resource Conservation and Recovery Act) operable unit investigations (Westinghouse Hanford Company).

Figure 3.1 shows the well site locations of the upper basalt confined aquifer test intervals examined as part of this report. Pertinent information concerning well completions, principal hydrogeologic units monitored, and hydraulic tests performed for the individual test well sites is provided in the appendix. Additional information concerning the test wells is also presented in Spane and Raymond (1993). 


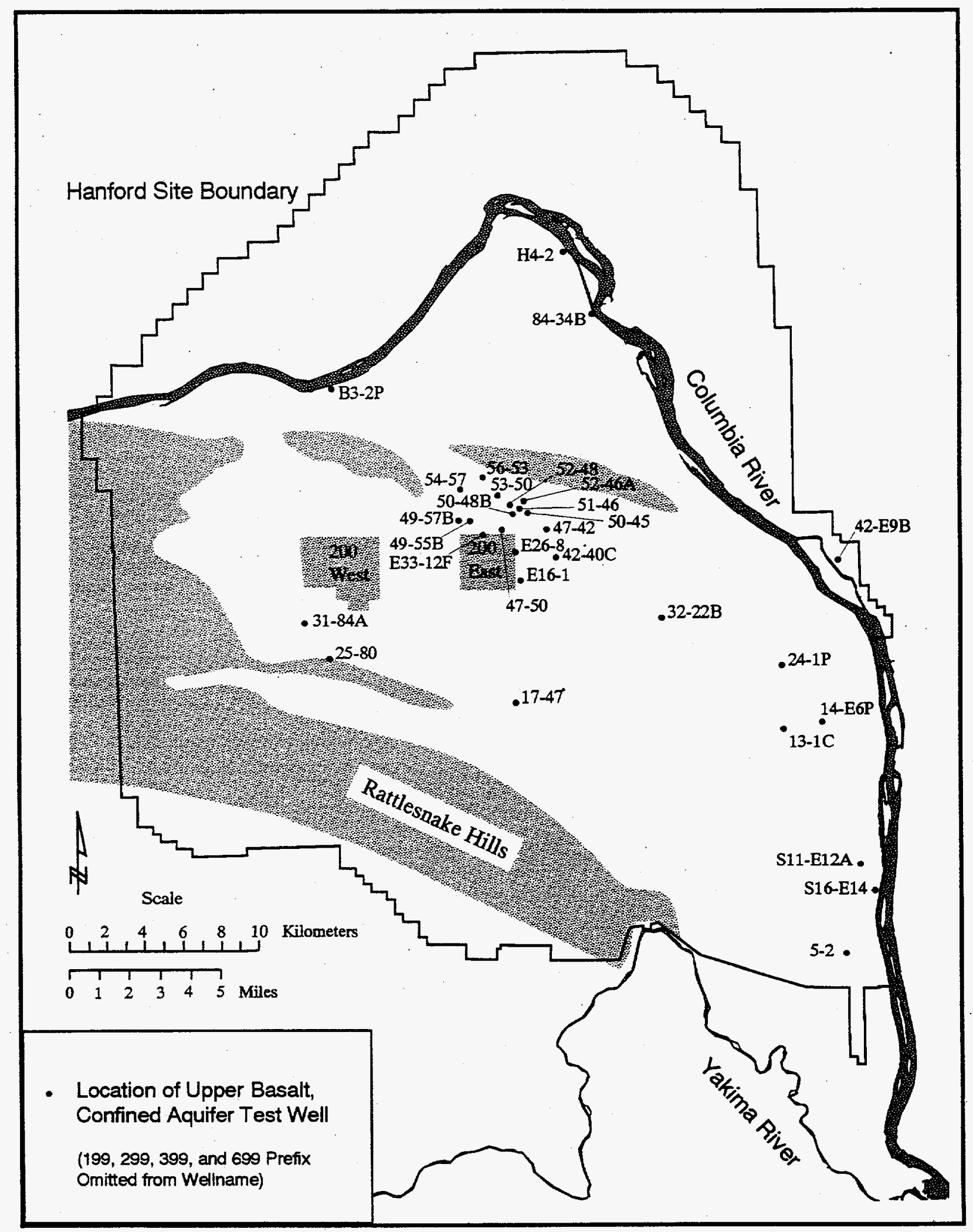

Figure 3.1. Location of Upper Basalt Confined Aquifer Test Sites 


\subsection{Test Analysis Method Description}

In hydrologic characterization investigations, in situ hydraulic properties of subsurface units are commonly determined by analytical techniques that relate the effects of a known imposed stress to hydraulic properties (i.e., transmissivity, storativity). Standard hydrologic test methods commonly used include constant-rate discharge tests, in which ground water is removed from the test interval at a constant rate for an extended period of time, and slug tests, which are characterized by the instantaneous removal or injection of fluid. Analysis of the drawdown and recovery phases of these hydrologic tests is normally accomplished by type-curve fitting of $\log$-log plots or straight-line analysis of semilogarithmic data plots of pressure change versus time. Recent developments in hydrologic test analysis based on the derivative of pressure with respect to the natural logarithm of time have been shown to significantly improve the diagnostic and quantitative analysis of slug and pumping tests. The improvement in test analysis is attributed to the sensitivity of pressure derivatives to various test/ formation conditions. Specific applications for which derivatives are particularly useful include the following:

- determining formation response (leaky versus nonleaky) and boundary conditions (impermeable or constant head) that are evident within the test data

- assisting in the selection of the appropriate type-curve solution through combined typecurve/derivative plot matching

- determining when infinite-acting, radial flow conditions are established and, therefore, when nonleaky, confined aquifer, straight-line analysis methods are applicable

- reducing the ambiguity of type-curve selection in confined aquifer slug test analysis.

Pressure derivative analysis, used in conjunction with standard test analysis methods, is discussed in Spane (1993) and Spane and Wurstner (1993). The basis for the analytical procedures used in the test reanalyses is taken from these previous reports and is presented below.

\subsection{Constant-Rate Discharge Tests}

During constant-rate discharge tests (also referred to as constant-rate pumping tests), ground water is withdrawn from a well with discharge regulated and maintained at a constant rate. Water-level response within the well is monitored during the active pumping phase and during the subsequent recovery phase after termination of pumping. The analysis of drawdown and recovery water-level response within the stress well (and any nearby monitored wells) provides a means for estimating the hydraulic properties of the tested aquifer, as well as for discerning formational and nonformational flow conditions (e.g., wellbore storage, well inefficiency, presence of boundaries). Standard analytical methods that are used for constant-rate pumping tests include type-curve matching and straight-line methods. 
In ground-water hydrology, type-curve matching methods (Theis 1935; Hantush 1964) are normally reserved for analyzing individual or collective observation well response. Type-curve analysis is not normally used for quantitative analysis of the pumped well because part of the drawdown or recovery water-level response within the stress well is associated with well/formation inefficiencies or damage induced by the drilling process. In the petroleum industry, the effects of well/formation inefficiencies or damage are lumped together and referred to as "skin effect." In petroleum reservoir analysis, storativity (S) is independently estimated for the test formation; transmissivity $(T)$ and skin effect $\left(s_{k}\right)$ are calculated simultaneously by matching the log-log drawdown or recovery response with appropriate type curves for various skin-effect conditions (Earlougher 1977).

For straight-line analysis methods, the rate of change of water levels within the well during drawdown and/or recovery is analyzed to estimate hydraulic properties. Because skin effects are constant with time during constant-rate tests, straight-line methods can be utilized to quantitatively analyze the water-level response in both pumped and observation wells. In ground-water hydrology, the semilogarithmic, straight-line analysis techniques commonly used are based on either the Cooper and Jacob (1946) method (for drawdown analysis) or the Theis (1935) recovery method (for recovery analysis). These methods are theoretically restricted to the analysis of test responses from wells that fully penetrate nonleaky, homogeneous, isotropic, confined aquifers.

The straight-line solutions represent an approximation of the general equation describing radial flow to a well and are valid only after a specified period of time and after infinite-acting, radial flow conditions have been established. Infinite-acting, radial flow conditions are indicated during testing when the change in pressure, at the point of observation, increases in proportion to the logarithm of time. Lohman (1972) indicates that the time ( $t$ ) required for the straight-line approximation to be valid (mathematically) can be calculated from the following:

$$
t \geq\left(r^{2} S\right) /(4 T u)
$$

where $r$ is observation distance from the pumped well $(\mathrm{L})$ and $\mathrm{u}$ equals 0.01 (dimensionless).

The recent development of pressure derivative methods (Bourdet et al. 1983, 1984, 1989; EhligEconomides 1988) has significantly improved the analysis of pumping tests, using type-curve or straight-line methods. The improvement in hydrologic test analysis through use of pressure derivatives is attributed to the sensitivity of the derivative response to small variations in the rate of pressure change that occurs during testing, which would otherwise be less obvious with standard pressure change versus time analysis. The sensitivity of pressure derivatives to pressure change responses facilitates their use in identifying the effects of wellbore storage and boundaries and the presence of radial flow conditions within the test data.

Figure 4.1 shows the pattern of dimensionless pressure $\left(\mathrm{p}_{\mathrm{D}}\right)$ and the dimensionless pressure derivative $\left[\left(t_{D} / C_{D}\right) p_{D}\right.$ '] during a constant-rate test for a stress well that fully penetrates a nonleaky, 


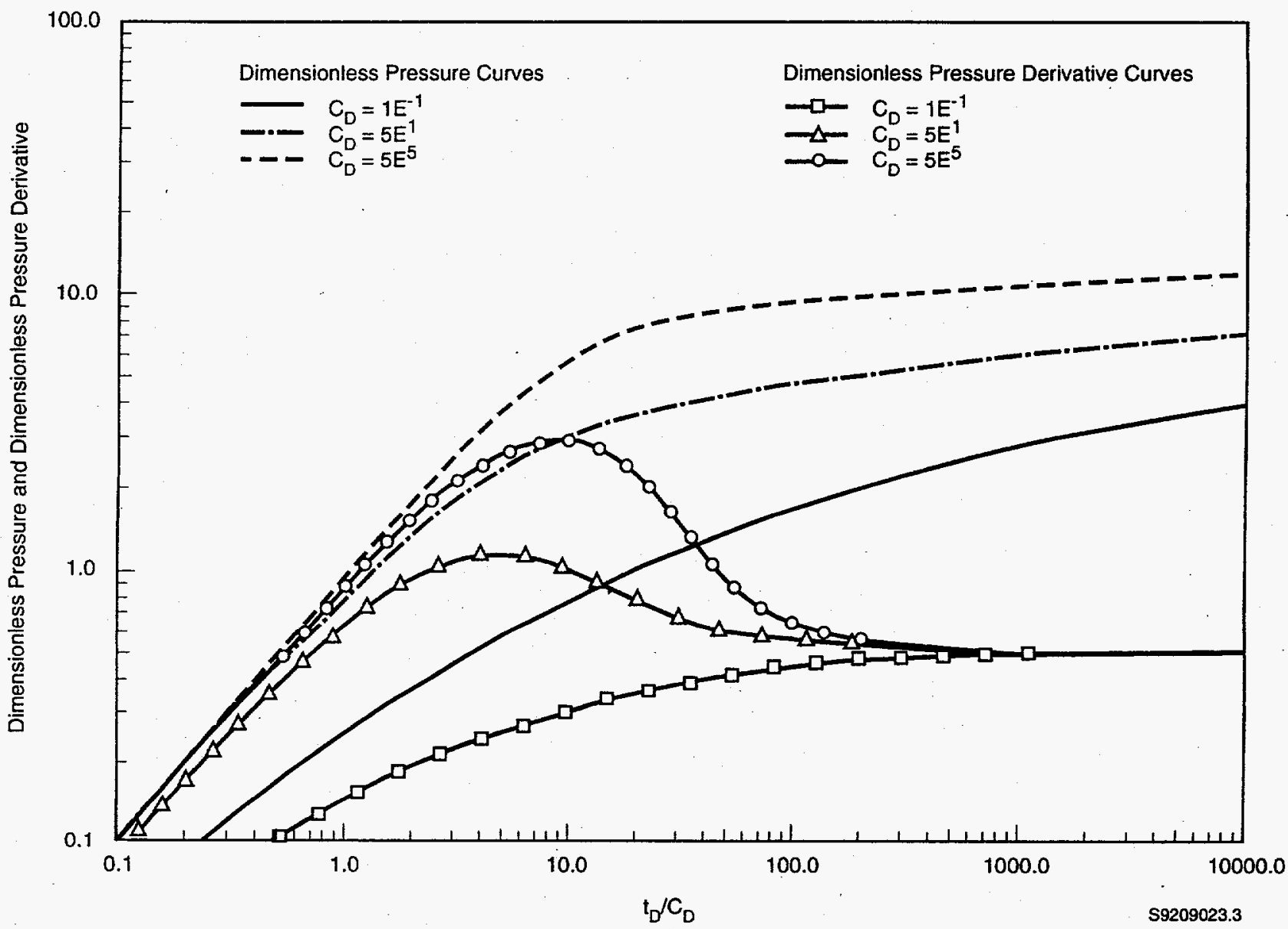

Figure 4.1. Dimensionless Pressure and Dimensionless Pressure Derivative Curves for Constant-Rate Discharge Tests in Nonleaky Confined Aquifers (adapted from Spane and Wurstner 1993)

homogeneous, isotropic, confined aquifer for various dimensionless wellbore storage conditions (i.e., $C_{D}>0$ ). Dimensionless parameters shown in the figure are defined as

$$
\begin{aligned}
& p_{D}=(2 \pi T / Q) \Delta h \\
& C_{D}=r_{c}{ }^{2} / 2\left(r_{w}{ }^{2} S\right) \\
& t_{D}=(T t) /\left(r_{w}{ }^{2} S\right)
\end{aligned}
$$


where $Q=$ pumping discharge rate $\left(L^{3} / T\right)$

$$
\begin{aligned}
\Delta h & =\text { water-level change }(L) \\
r_{c} & =\text { stress well casing radius }(L) \\
r_{w} & =\text { stress well radius in test interval }(L) \\
t & =\text { time since pumping started }(T) .
\end{aligned}
$$

The $\mathrm{P}_{\mathrm{D}}$ type curves were generated using the program TYPCURV (Novakowski 1990). The $\left(t_{D} / C_{D}\right) p_{D}$ ' curves were produced by using the generated $p_{D}$ curve data as input to the DERIV program described in Spane and Wurstner (1993). The values of $C_{D}$ shown in Figure 4.1 encompass the range for storativity commonly cited for confined aquifer systems (i.e., $S=10^{-3}$ to $10^{-5}$ [Heath 1983]).

As indicated in Figure 4.1, wellbore storage produces a characteristic "hump" in the pressure derivative plot, which increases in amplitude and duration as the associated dimensionless wellbore storage value, $C_{D}$, increases. A Theisian response that is characterized by no wellbore storage effects cannot be shown in the figure because $C_{D}=0$. However, because of the similarity displayed by all low $C_{D}$ curves (i.e., $C_{D} \leq 0.1$ ), the absence of wellbore storage effects can be approximated by the $C_{D}$ curve $=0.1$ shown in the figure. Infinite-acting, radial flow conditions are indicated during testing when the change in pressure at the point of observation increases in proportion to the logarithm of time. This is indicated when the pressure derivative curve becomes horizontal (i.e., when the pressure derivative becomes constant) at a $\mathrm{P}_{\mathrm{D}}$ ' value equal to 0.5 . Test data displaying this derivative pattern can be analyzed using confined aquifer, semilogarithmic straight-line methods (e.g., Cooper and Jacob 1946). For most test situations, infinite-acting, radial flow conditions are established for test times with $t_{D} / C_{D}$ values greater than approximately 60 (Earlougher 1977 ).

The presence of nonradial flow conditions caused by vertical flow, leaky aquifer behavior, or presence of boundaries is denoted on a pressure derivative plot by a diagnostic response pattern that deviates significantly from the horizontal radial flow-line region of the graph (i.e., $\left[t_{D} / C_{D}\right] p_{D}{ }^{\prime}=0.5$ ). In comparison, these nonradial flow conditions are less obvious on a dimensionless pressure change plot without the derivative. Nonradial flow is suggested only by a subtle deviation from the pressure change plot. Figure 4.2 presents examples of diagnostic dimensionless pressure change and pressure derivative plots for selected heterogeneous formation test conditions. A more complete treatment of diagnostic response patterns is provided by Ehlig-Economides (1988) and Horn (1990).

Distinctive log-log derivative curves can also be developed for leaky confined aquifer response for the two cases where confining layer storage is and is not significant. For these test formation response conditions, type-curve values presented in Hantush (1964) can be used with the derivative program provided in Spane and Wurstner (1993) to generate the appropriate derivative response curve. A detailed discussion of the use of leaky confined aquifer pressure derivative analysis is provided in Spane (1993) and Spane and Wurstner (1993).

The general procedure utilized for reanalysis of available constant-rate discharge tests for wells completed in the upper basalt confined aquifer is outlined below. 


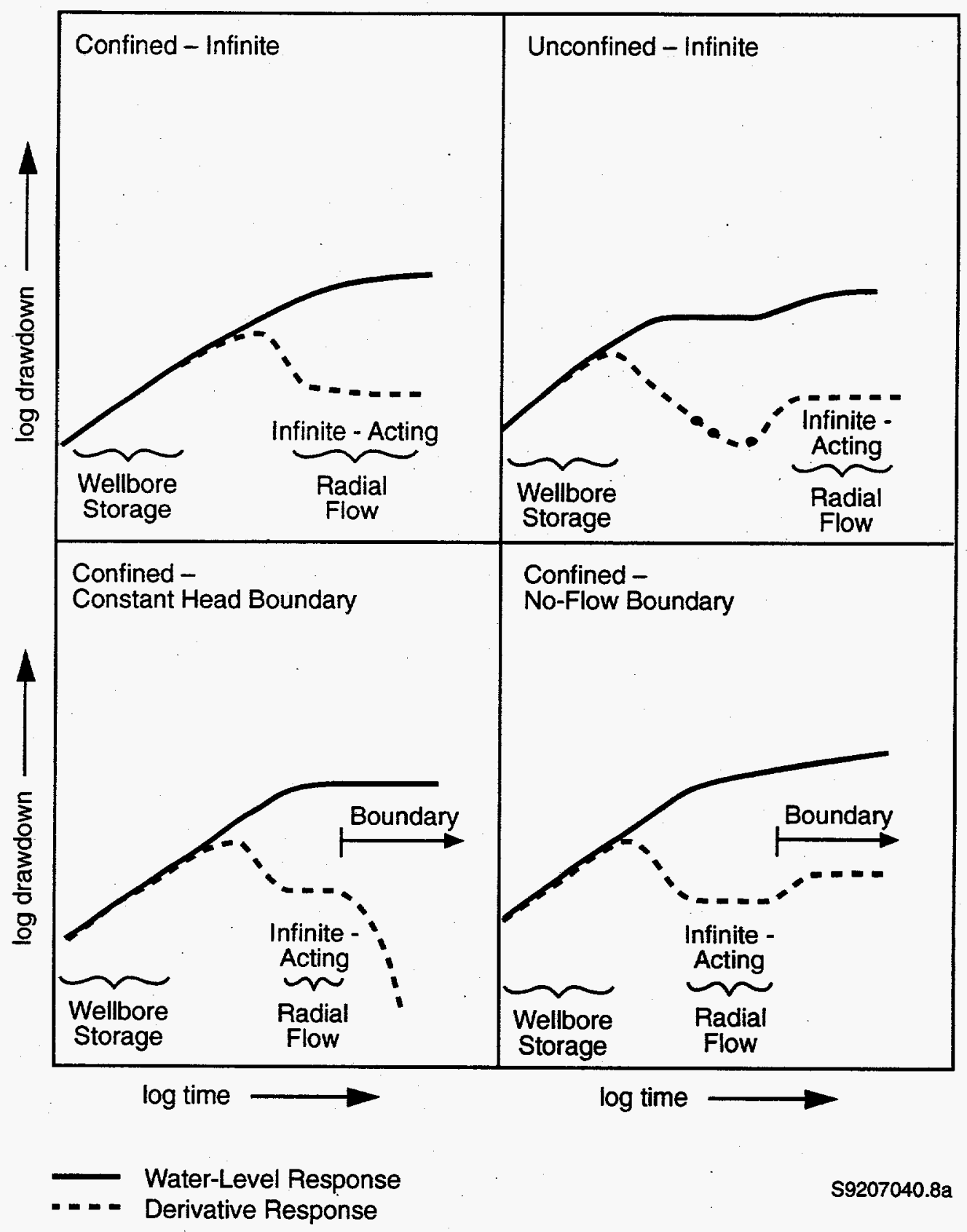

Figure 4.2. Diagnostic Log-Log Pressure and Pressure Derivative Plots for Various Hydrogeologic Formation/Boundary Conditions (adapted from Spane and Wurstner 1993) 


\section{Nonleaky Confined Aquifers}

1. Construct a $\log$-log plot of the drawdown data and data derivative versus the log of time.

2. Evaluate the drawdown data and data derivative pattern (i.e., diagnostic analysis) to ascertain the formation response model and whether radial flow conditions have been established during the test.

3. Calculate the transmissivity of the test interval based on the analysis of the indicated radial flow section of the test data (if present) using the Cooper and Jacob (1946) semilogarithmic straightline method, provided that the data record analyzed satisfies the " $u$ " time criteria listed in Equation (1).

4. If the semilogarithmic straight-line analysis method is not applicable, composite log-log typecurve matching of the drawdown and drawdown derivative response should be utilized to calculate transmissivity using type-curve relationships presented in Papadopulos and Cooper (1967), together with their associated derivative curve response (i.e., calculated using DERIV in Spane and Wurstner 1993). It should be noted that the type-curve analysis procedure assumes either that skin effects are equal to zero or can be independently determined.

\section{Leaky Confined Aquifers}

1. Follow the first three steps outlined for nonleaky confined aquifer conditions.

2. If radial flow conditions are not established prior to the onset of significant leakage response, composite log-log type-curve matching of the drawdown and drawdown derivative response should be utilized using type-curve relationships presented in Hantush (1964), together with their associated derivative-curve response (i.e., calculated using DERIV in Spane and Wurstner 1993). Wellbore storage effects can also be accounted for following the procedure described in Fenske (1977).

3. For leaky conditions without significant aquitard storage, the Hantush (1964) semilogarithmic straight-line method can also be used. This method, however, has only limited application for pumping well analysis because it cannot be used if significant wellbore storage effects influence the slope of the selected straight-line segment. It should be noted that the leaky type-curve analysis procedure assumes either that skin effects are equal to zero or can be independently determined.

These procedures pertain only to the analysis of drawdown data obtained during constant-rate tests. Recovery data for constant-rate tests can also be analyzed using the same procedures, provided that the recovery buildup pressure (i.e., the observed formation pressure during the recovery minus the observed formation pressure at the termination of testing) is plotted versus the equivalent time function described in Agarwal (1980). The Agarwal equivalent time function accounts for the duration of the discharge time period, thereby permitting the use of drawdown-type curves for the analysis of recovery data. The equivalent time function $\left(t_{e}\right)$ is defined in Agarwal (1980) as

$$
t_{e}=\left(t \times t^{\prime}\right) /\left(t+t^{\prime}\right)
$$


where $t$ is duration of the discharge test $(T)$, and $t^{\prime}$ is the time since discharge terminated $(T)$. If radial flow conditions have been established during the recovery period, the straight-line analysis methods described in Theis (1935) or Agarwal (1980) can be utilized.

\subsection{Slug Tests}

The analytical solution for a slug test response for a fully penetrating stress well with a finite radius within a confined aquifer containing a compressible fluid was first presented by Cooper et al. (1967). Type curves were also presented that related dimensionless head response $\left(H_{D}\right)$ to the dimensionless time parameter ( $(B)$ for various values of the dimensionless storage parameter $(\alpha)$ where

$$
\begin{gathered}
H_{D}=H / H_{o} \\
B=T t / r_{c}{ }^{2} \\
\alpha=r_{w}{ }^{2} S / r_{c}{ }^{2}
\end{gathered}
$$

where $H$ is the observed head at time $t$, minus pretest static head level in well (L) and $H_{o}$ is the instantaneous head change applied to the well at the start of the test $(L)$. The type curves presented by Cooper et al. (1967) can be used to match slug test response data at the stress well to solve for T and S using Equations (7) and (8), respectively.

As indicated in Figure 4.3, type-curve responses for storativity values of $10^{-2}\left(\alpha \approx 10^{-2}\right)$ and less are very similar in shape. This similarity in type-curve shape prompted Cooper et al. (1967) to conclude that

... because the matching of the data plot to the type curves depends on the shapes of the type curves, which differ only slightly when $\alpha$ differs by an order of magnitude, a determination of $S$ by this method has questionable reliability.

The ambiguity in determining the storativity is greatly reduced, however, when the derivative of the dimensionless head is plotted. In contrast to the normal dimensionless head type curves shown in Figure 4.3, the shape and amplitude of the dimensionless head derivative curves are strongly influenced by the storativity of the aquifer. As a means of improving the selection of the correct type curve, Ostrowski and Kloska (1989) presented a slug test analysis procedure that employed the simultaneous type-curve matching of the dimensionless pressure (i.e., $\mathrm{H} / \mathrm{H}_{\mathrm{o}}$ ) versus time and the derivative of dimensionless pressure versus time. The technique is preferable to the procedure described by Cooper et al. (1967) for dimensionless pressure versus time, in that the ambiguity in type-curve selection is significantly reduced.

Although slug test derivative type curves improve the analysis match for test intervals that are completed in homogeneous confined aquifers, they cannot be used diagnostically like pumping test derivatives to provide definitive information concerning aquifer heterogeneity, nonradial flow 


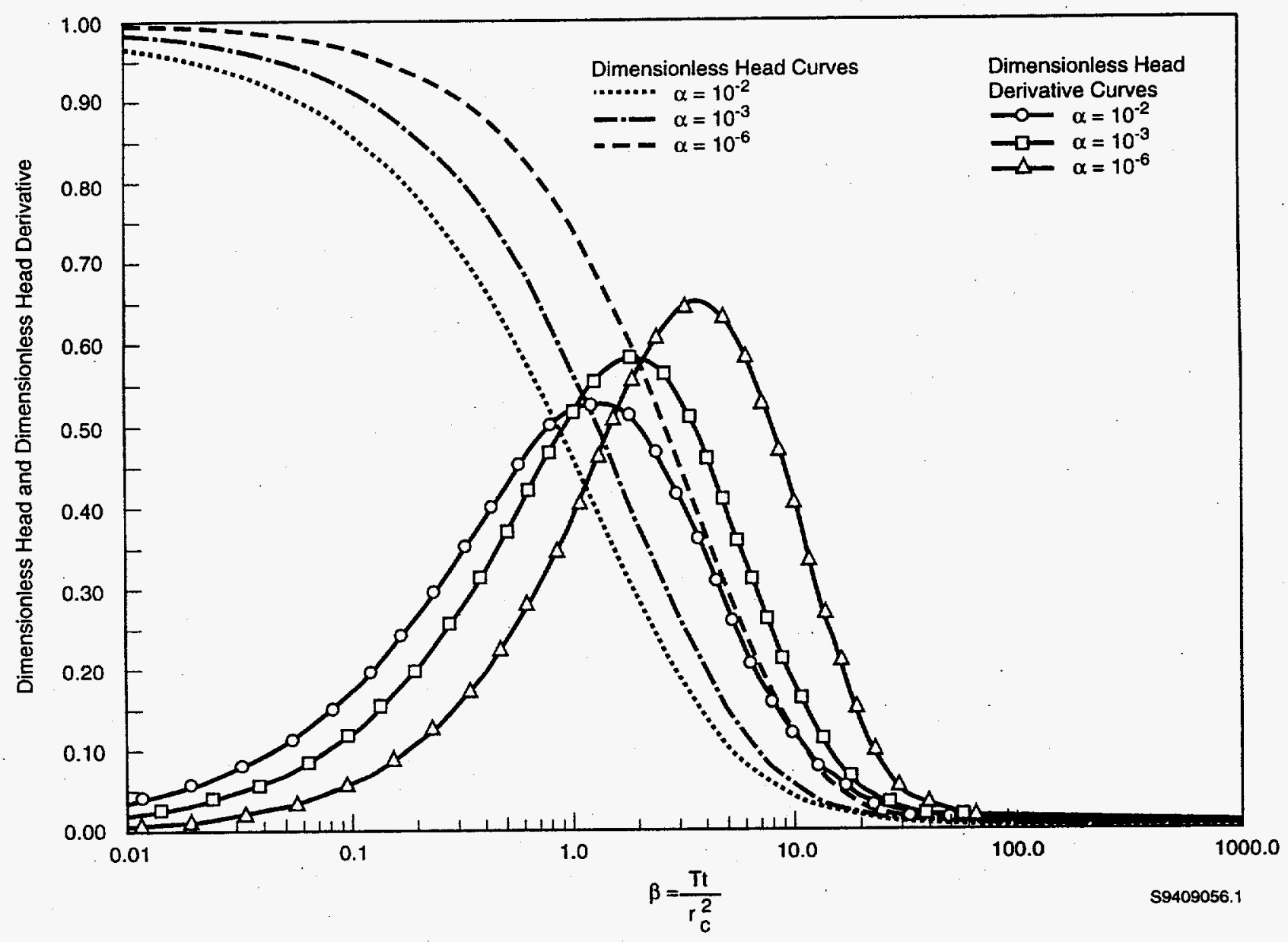

Figure 4.3. Dimensionless Head and Dimensionless Head Derivative Type Curves for Nonleaky Confined Aquifer Slug Tests (adapted from Spane and Wurstner 1993)

conditions, presence of boundaries, etc. A method is available, however, for converting slug test data to an equivalent head response that would be obtained during a constant-rate pumping test (Peres 1989; Peres et al. 1989). Once equivalent head values are obtained from the converted slug test data, equivalent head derivatives can be calculated using the procedure previously identified for constant-rate tests. The equivalent head and derivative responses can then be evaluated diagnostically to ascertain the formation response conditions existing during the test. To make the conversion process practical, a slug test data set that contains nearly complete recovery (i.e., $\mathrm{H} / \mathrm{H}_{\mathrm{o}} \approx 0.0$ ) should be available.

The general procedure utilized for reanalysis of available slug test data for wells completed in the upper basalt confined aquifer is outlined below:

1. Convert the slug test data to an equivalent constant-rate test following the procedure presented in Peres et al. (1989). Construct a log-log plot of the equivalent head and equivalent head derivative versus the log of time. 
2. Evaluate the equivalent head data and equivalent head derivative pattern (i.e., diagnostic analysis) to ascertain the formation response model and whether nonradial flow conditions (e.g., leakage) have occurred during the test.

3. If nonleaky flow conditions are indicated, calculate the transmissivity of the test interval using the combined slug test type curve and derivative curve method described in Ostrowski and Kloska (1989) and Spane and Wurstner (1993).

4. If leaky flow conditions are indicated, calculate the transmissivity of the test interval using either of two methods - depending on when leakage effects become significant. For situations where leakage effects are not apparent during the first $70 \%$ of recovery (i.e., $H_{D}=1.0$ to 0.3 ), use the nonleaky procedure outlined in step 3 to analyze the indicated nonleaky data section.

For tests where leakage affects more than $30 \%$ of the slug test recovery, leaky slug test type curves and associated derivatives were developed following the procedure presented in Spane (1994). This procedure is dependent on the relationship previously established by Peres (1989) and Peres et al. (1989) between slug and constant-rate tests and the availability of leaky constant-rate test type curves. Transmissivity of the test interval is then determined using the combined slug test type-curve and derivative curve-matching procedure, as discussed in step 3 for nonleaky test conditions. 


\subsection{Hydraulic Test Result Summary}

Hanford Site test data from 35 single-well test intervals within the upper basalt confined aquifer system were evaluated. The principal hydrogeologic unit distribution for test intervals evaluated are, from highest to least: Rattlesnake Ridge interbed $(n=22)$, Elephant Mountain Member interflow contacts $(n=7)$, and Levey interbed $(n=2)$. In addition, four of the test intervals have composite hydrogeologic unit completions. Hydraulic test data available for the test intervals are primarily limited to slug tests $(n=18$; total tests $=36)$ and constant-rate discharge tests $(n=35$; total tests $=42$ ). Only 18 of the 35 test intervals have both slug and constant-rate discharge test data.

Figures 5.1 and 5.2 show the comparison between previously reported transmissivity values and reanalysis estimates for slug and constant-rate pumping tests, respectively. As shown, approximately $55 \%$ of the reanalysis slug test and $75 \%$ of the constant-rate test transmissivity values are within a factor of two of the previously reported estimates. For a majority of the hydrologic tests, previously reported transmissivity values are higher than reanalysis estimates. This overestimation is attributed to a number of factors, including, in many cases, a misapplication of nonleaky confined aquifer analysis methods in previous analysis reports to tests that exhibit leaky confined aquifer response behavior.

Figure 5.3 shows the comparison of reanalysis transmissivity values obtained for the 18 test intervals having both slug and constant-rate pumping test results. As indicated in the figure, most transmissivity estimates obtained from slug and constant-rate pumping tests have a correspondence within a factor of three. This level of correspondence is similar to previous slug test assessments reported in Papadopulos et al. (1973) and van der Kamp (1976).

Figure 5.4 shows a comparison of reanalysis transmissivity values for individual hydrogeologic units making up the upper basalt confined aquifer system. Results of the test reanalyses indicate a similar range for transmissivity values for the various hydrogeologic units. Approximately $90 \%$ of the calculated transmissivity values for upper basalt confined aquifer hydrogeologic units occur within the range of $10^{\circ}$ to $10^{2} \mathrm{~m}^{2} / \mathrm{d}$, with $65 \%$ of the calculated values occurring between $10^{1}$ to $10^{2} \mathrm{~m}^{2} / \mathrm{d}$. These summary findings are consistent with the general range for basalt interflow contact zones and sedimentary interbeds within the Saddle Mountains Basalt reported in Gephart et al. (1979), Strait and Mercer (1987), and DOE (1988). 


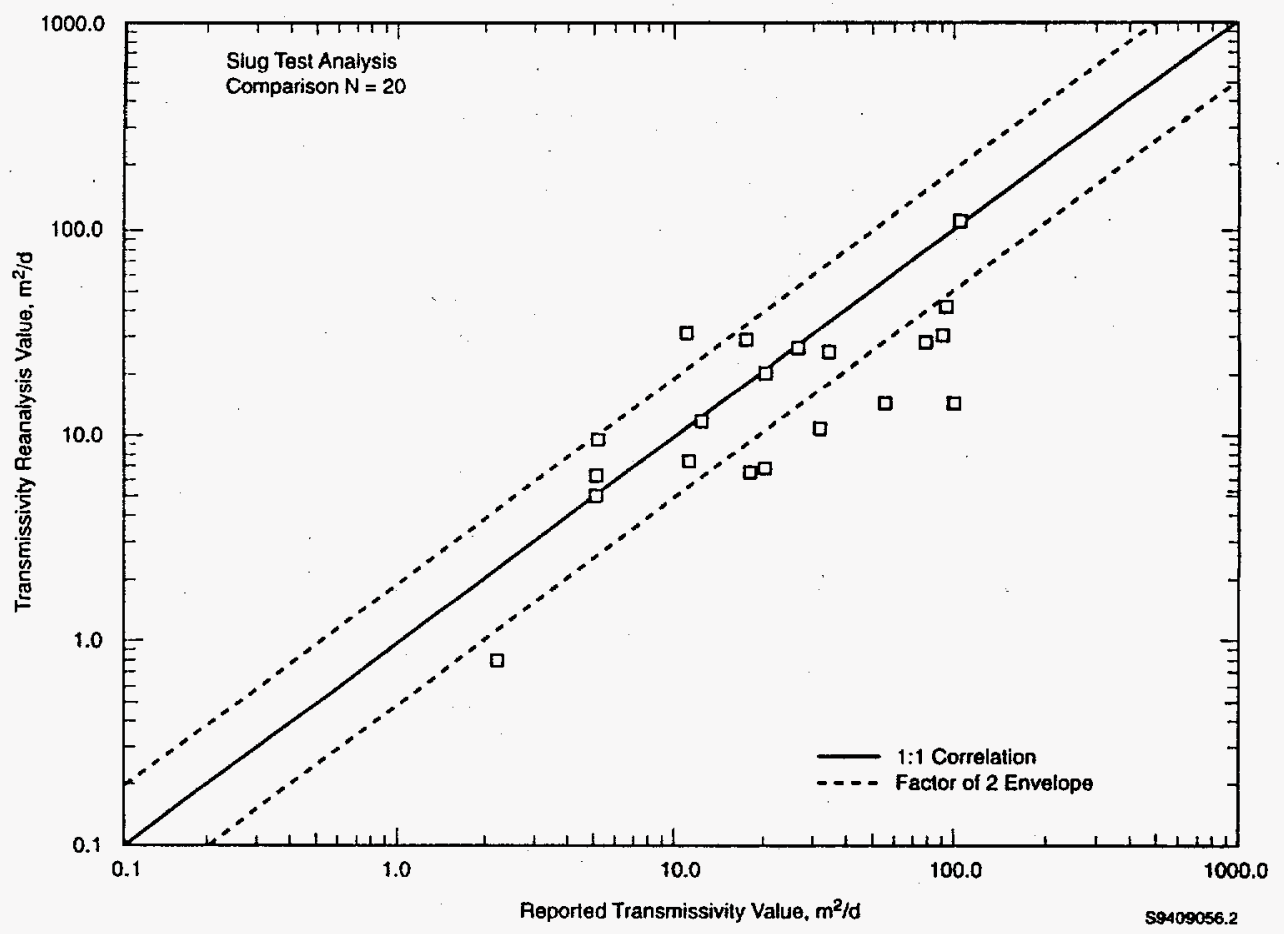

Figure 5.1. Comparison of Reanalysis and Previously Reported Slug Test Transmissivity Estimates for Upper Basalt Confined Aquifer Test Intervals

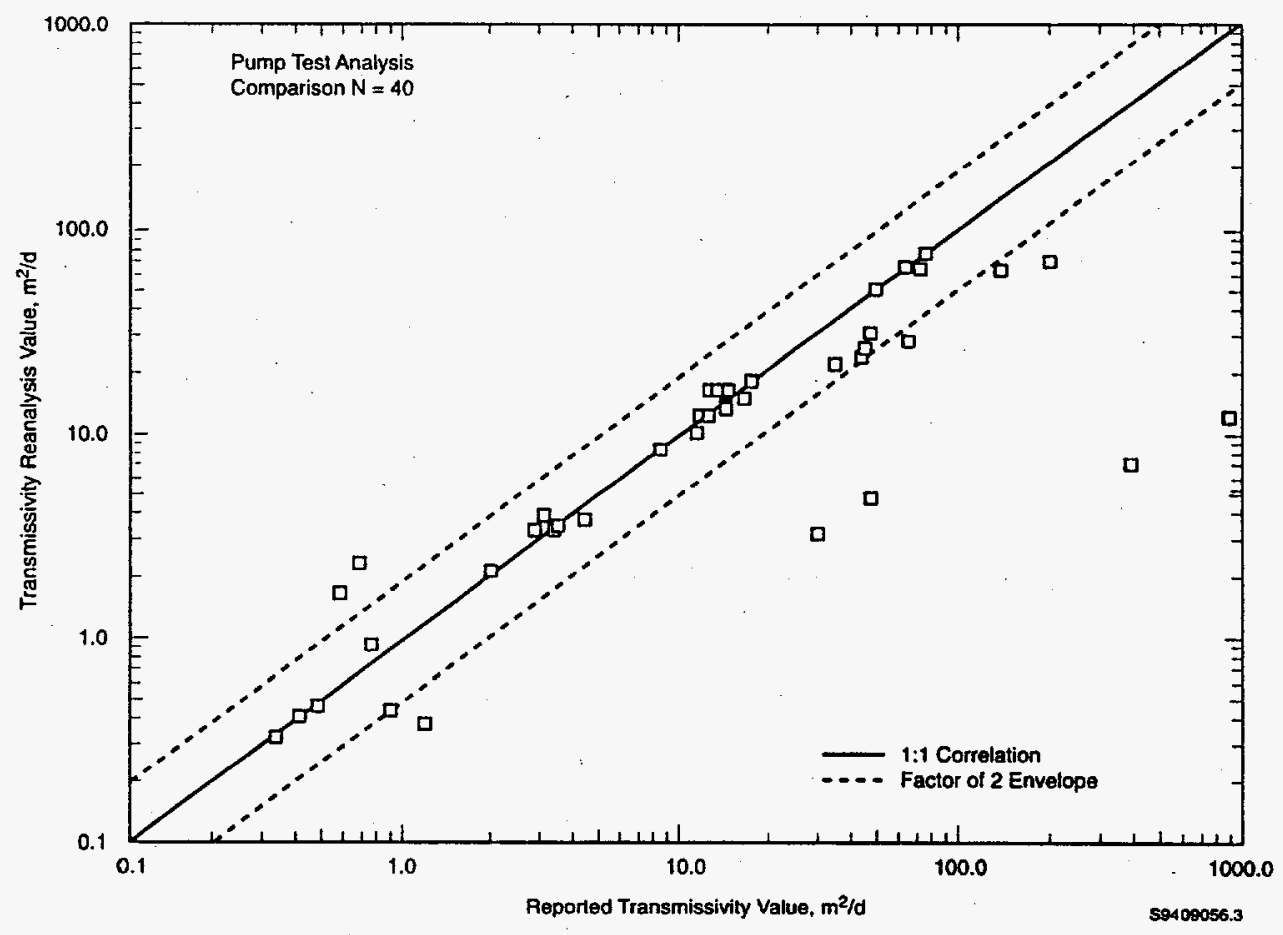

Figure 5.2. Comparison of Reanalysis and Previously Reported Constant-Rate Pumping Test Transmissivity Estimates for Upper Basalt Confined Aquifer Test Intervals 


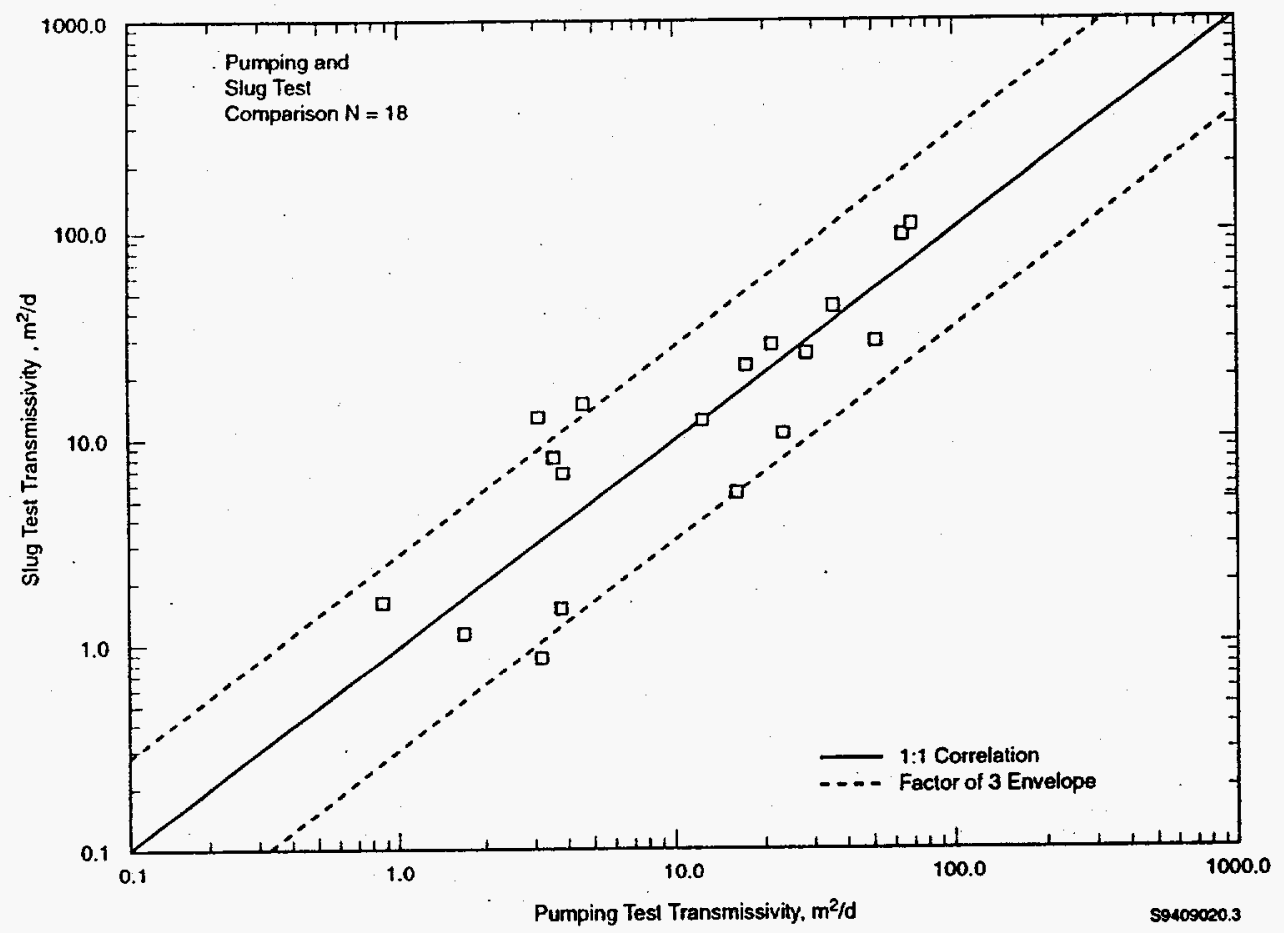

Figure 5.3. Comparison of Reanalysis Slug and Constant-Rate Pumping Test Transmissivity Estimates for Upper Basalt Confined Aquifer Test Intervals

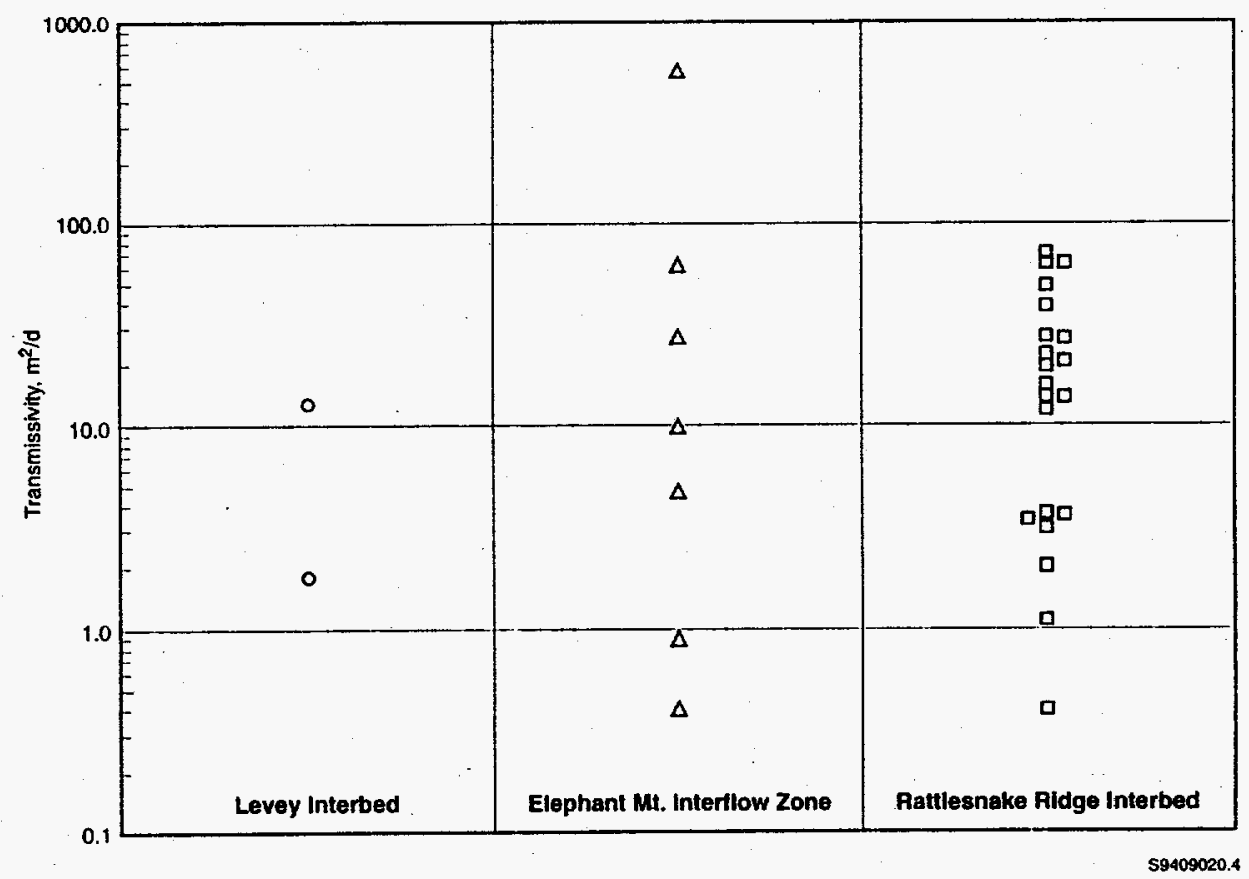

Figure 5.4. Distribution of Reanalysis Best Estimate Transmissivity Values for Individual Hydrogeologic Units Within the Upper Basalt Confined Aquifer 


\subsection{References}

Agarwal, R. G. 1980. "A New Method to Account for Producing Time Effects When Drawdown Type Curves Are Used to Analyze Pressure Buildup and Other Test Data." Presented at the 1980 Society of Petroleum Engineers Annual Technical Conference and Exhibition, Sept. 21-24, 1980, Dallas. SPE Paper 9289.

Bourdet, D., T. M. Whittle, A. A. Douglas, and Y. M. Pirard. 1983. "A New Set of Type Curves Simplifies Well Test Analysis." World Oil, May 1983, pp. 95-106.

Bourdet, D., A. Alagoa, J. A. Ayoub, and Y. M. Pirard. 1984. "New Method Enhances Well Test Interpretations." Wbrld Oil, September 1984, pp. 37-44.

Bourdet, D., J. A. Ayoub, and Y. M. Pirard. 1989. "Use of Pressure Derivative in Well-Test Interpretation." Society of Petroleum Engineers, SPE Formation Evaluation, June 1989, pp. 293-302.

Cooper, H. H., Jr., and C. E. Jacob. 1946. "A Generalized Graphical Method for Evaluating Formation Constants and Summarizing Well-Field History." American Geophysical Union, Transactions 27(4):526-534.

Cooper, H. H., Jr., J. D. Bredehoeft, and I. S. Papadopulos. 1967. "Response of a Finite-Diameter Well to an Instantaneous Charge of Water." Water Resources Research 3(1):263-269.

DOE (U.S. Department of Energy). 1982. Site Characterization Report for the Basalt Waste Isolation Project. DOE/RL 82-3, 3 Vols., U.S. Department of Energy, Richland, Washington.

DOE (U.S. Department of Energy). 1988. Consultation Draft, Site Characterization Plan, Reference Repository Location, Hanford Site, Washington. DOE/RW-0164, Vols. 1 and 2, U.S. Department of Energy, Washington, D.C.

Earlougher, R. C., Jr. 1977. "Advances in Well Test Analysis." Society of Petroleum Engineers, Monograph Vol. 5, Henry L. Doherty Series.

Ehlig-Economides, C. 1988. "Use of the Pressure Derivative for Diagnosing Pressure-Transient Behavior." Journal of Petroleum Technology, October 1988, pp. 1280-1282.

Fenske, P. R. 1977. "Radial Flow With Discharging-Well and Observation-Well Storage," Journal of Hydrology 32:87-96.

Gephart, R. E., R. C. Arnett, R. G. Baca, L. S. Leonhart, F. A. Spane, Jr., D. A. Palumbo, and S. R. Strait. 1979. Hydrologic Studies Within the Columbia Plateau Washington: An Integration of Current Knowledge. RHO-BWI-ST-5, Rockwell Hanford Operations, Richland; Washington

Hantush, M. S. 1964. "Hydraulics of Wells." In Advances in Hydroscience. ed. V. T. Chow, Vol. 1, pp. 282-433. Academic Press, New York. 
Heath, R. C. 1983. Basic Ground-Water Hydrology, U.S. Geological Survey, Water Supply Paper 2220.

Horn, R. N. 1990. Modern Well Test Analysis: A Computer-Aided Approach. Petroway, Inc., Palo Alto, California; distributed by the Society of Petroleum Engineers, Richfield, Texas.

Lohman, S. W. 1972. Ground-Water Hydraulics, U.S. Geological Survey Professional Paper 708.

Novakowski, K. S. 1990. "Analysis of Aquifer Tests Conducted in Fractured Rock: A Review of the Physical Background and the Design of a Computer Program for Generating Type Curves." Ground Water 28(1):99-105.

Ostrowski, L. P., and M. B. Kloska. 1989. "Use of Pressure Derivatives in Analysis of Slug Test or DST Flow Period Data." Society of Petroleum Engineers, SPE Paper 18595.

Papadopulos, I. S., and H. H. Cooper, Jr. 1967: "Drawdown in a Well of Large Diameter." Water Resources Research 3(1):241-244.

Papadopulos, I. S., J. D. Bredehoeft, and H. H. Cooper, Jr. 1973. "On the Analysis of Slug Test Data." Water Resources Research 9(4):1087-1089.

Peres, A. M. 1989. Analysis of Slug and Drillstem Tests. Ph.D. Dissertation, University of Tulsa, Tulsa, Oklahoma.

Peres, A. M., M. Onur, and A. C. Reynolds. 1989. "A New Analysis Procedure for Determining Aquifer Properties from Slug Test Data." Water Resources Research 25(7):1591-1602.

Reidel, S. P., and K. R. Fecht. 1981. "Wanapum and Saddle Mountains Basalts of the Cold Creek Syncline Area." In Subsurface Geology of the Cold Creek Syncline, eds. C. W. Myers and S. M. Price, pp. 3-1 to 3-45. RH0-BWI-ST-14, Rockwell Hanford Operations, Richland, Washington.

Spane, F. A., Jr. 1993. Selected Hydraulic Test Analysis Techniques for Constant-Rate Discharge Tests. PNL-8539, Pacific Northwest Laboratory, Richland, Washington.

Spane, F. A., Jr. 1994. Applicability of Slug Interference Test for Hydraulic Characterization of Unconfined Aquifers: (1) Analytical Assessment. PNL-SA-24283, Pacific Northwest Laboratory, Richland, Washington.

Spane, F. A., Jr., and R. G. Raymond. 1993. Preliminary Potentiometric Map and Flow Dynamic Characteristics for the Upper-Basalt Confined Aquifer System. PNL-8869, Pacific Northwest Laboratory, Richland, Washington.

Spane, F. A., Jr., and S.K. Wurstner. 1993. "DERIV: A Program for Calculating Pressure Derivatives for Use in Hydraulic Test Analysis." Ground Water 31(5):814-822. 
Strait, S. R., and R. B. Mercer. 1987. Hydraulic Property Data from Selected Test Zones on the Hanford Site. SD-BWI-DP-051, Rockwell Hanford Operations, Richland, Washington.

Theis, C. V. 1935. "The Relationship Between the Lowering of the Piezometric Surface and the Rate and Duration of Discharge of a Well Using Ground-Water Storage." American Geophysical Union, Transactions, pt. 2, pp. 519-524; reprinted in Society of Petroleum Engineers, 1980, "Pressure Transient Testing Methods." SPE Reprint Series, 14:27-32.

van der Kamp, G. 1976. "Determining Aquifer Transmissivity by Means of Well Response Tests: The Underdamped Case." Water Resources Research 12(1):71-77. 


\section{Appendix}

\section{Test Summaries}




\section{Appendix}

\section{Test Summaries}

This appendix contains a synopsis table and the abbreviated reanalysis summaries for the tests conducted within the upper basalt confined aquifer. The following wells were used in this reanalysis:

Hanford Site Well Designations

$\begin{array}{ll}\text { 199-B3-2P } & 699-47-42 \\ 199-H 4-2 & 699-47-50 \\ 299-E 16-1 & 699-49-55 B \\ 299-E 26-8 & 699-49-57 B \\ 299-E 33-12 & 699-50-45 \\ 399-5-2 & 699-50-48 \\ 699-S 16-E 14 & 699-51-46 \\ 699-13-1 C & 699-52-46 A \\ 699-14-E 6 P & 699-52-48 \\ 699-24-1 P & 699-53-50 \\ 699-25-80 & 699-54-57 \\ 699-31-84 A & 699-56-53 \\ 699-42-40 C & 699-84-34 B\end{array}$

No reanalysis summaries are provided for test intervals in wells 699-S11-E12A, 699-17-47, 699-32-22B, and 699-42-E9B. See test summary table for comments.

Also included is a list of references and data sources for these tests. 
Table A.1. Test Summary Table

\begin{tabular}{|c|c|c|c|c|c|c|c|c|c|c|c|c|c|}
\hline $\begin{array}{c}\text { Hanford Well } \\
\text { Designation }\end{array}$ & $\begin{array}{l}\text { Principal } \\
\text { Hydro- } \\
\text { geologic } \\
\text { Unit }\end{array}$ & $\begin{array}{c}\text { Test Interval } \\
\text { (m) }\end{array}$ & $\begin{array}{l}\text { Slug Test } \\
\text { Type/Date }\end{array}$ & $\begin{array}{c}\text { Slug } \\
\text { Test } \\
\text { Stress } \\
\text { Level } \\
\text { (m-water) } \\
\end{array}$ & $\begin{array}{l}\text { Reported } \\
\text { Trans- } \\
\text { missivity } \\
\left(\mathrm{m}^{2} / \mathrm{d}\right) \\
\end{array}$ & $\begin{array}{c}\text { Reanalysis } \\
\text { Value } \\
\left(\mathrm{m}^{2} / \mathrm{d}\right)\end{array}$ & $\begin{array}{c}\text { Constant } \\
\text { Discharge } \\
\text { Test } \\
\text { Time/Date }\end{array}$ & $\begin{array}{c}\text { Discharge } \\
\text { Rate } \\
\text { (L/min) } \\
\end{array}$ & $\begin{array}{c}\text { Reported } \\
\text { Trans- } \\
\text { missivity } \\
\left(\mathrm{m}^{2} / \mathbf{d}\right)\end{array}$ & $\begin{array}{c}\text { Reanalysis } \\
\text { Value } \\
\left(\mathrm{m}^{2} / \mathrm{d}\right)\end{array}$ & $\begin{array}{c}\text { Best } \\
\text { Estimate } \\
\text { Trans- } \\
\text { missivity } \\
\left(\mathrm{m}^{2} / \mathrm{d}\right)\end{array}$ & $\begin{array}{c}\text { Data } \\
\text { Sources }\end{array}$ & Comments \\
\hline 199-B3-2P & $\begin{array}{l}\text { Elephant } \\
\text { Mt. } \\
\text { Rattlesnake } \\
\text { Ridge } \\
\text { Interbed. }\end{array}$ & $199.6 \cdot 237.1$ & . & - & - & & $\begin{array}{l}\text { 3-hr test; } \\
4 / 70\end{array}$ & 60.6 & 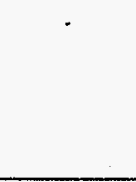 & (tna) & & $\begin{array}{l}\text { Deju } \\
\text { (1974); } \\
\text { PNL Files } \\
\quad .\end{array}$ & $\begin{array}{l}\text { Hydraulic } \\
\text { test results } \\
\text { not } \\
\text { analyzable; } \\
\text { hig h T } \\
\text { indicated }\end{array}$ \\
\hline 199-114-2 & $\begin{array}{c}\text { Rattlesnake } \\
\text { Ridge } \\
\text { Interbed }\end{array}$ & $109.7-118.3$ & $\begin{array}{l}\text { (2) Withdr; } \\
3 / 93\end{array}$ & $\begin{array}{l}6.27 \\
6.12\end{array}$ & : & $\begin{array}{l}1.7 \\
1.7\end{array}$ & $\begin{array}{c}2.5-\mathrm{hr} \\
\text { constant } \\
\text { drawdown } \\
\text { test } ; 3 / 93\end{array}$ & 12.5106 .6 & - & $\begin{array}{c}0.85 \\
\text { (constant } \\
\text { drawdown) } \\
0.73 \\
\text { (recovery) } \\
\end{array}$ & 1.1 & PNL Files & $\begin{array}{l}\text { Best est. } \\
\text { based on } \\
\text { average of } \\
\text { all tests }\end{array}$ \\
\hline 299-E16-1 & $\begin{array}{l}\text { Elephant } \\
\text { Mt. } \\
\text { Interflow }\end{array}$ & $149.4 \cdot 155.5$ & $\begin{array}{l}\text { Inject;11/82 } \\
\text { Withdr,11/82 }\end{array}$ & $\begin{array}{l}0.74 \\
0.83\end{array}$ & $\begin{array}{l}100 \\
52\end{array}$ & $\begin{array}{l}15 \\
15\end{array}$ & $\begin{array}{l}\text { 49-hr test; } \\
7 / 82\end{array}$ & 37.5 & $\begin{array}{c}46 \\
\text { (drawdown) } \\
109 \\
\text { (recovery) }\end{array}$ & $\begin{array}{l}4.5 \\
\text { (tna) }\end{array}$ & 10 & $\begin{array}{l}\text { Graham } \\
\text { et al. } \\
\text { (1984); } \\
\text { PNL Files }\end{array}$ & $\begin{array}{l}\text { Best est. } \\
\text { based on } \\
\text { average of } \\
\text { constant } \\
\text { discharge } \\
\text { drawdown } \\
\text { and slug } \\
\text { withdrawal }\end{array}$ \\
\hline 299-E26-8 & $\begin{array}{l}\text { Rattlesnake } \\
\text { Ridge } \\
\text { Interbed }\end{array}$ & $100.6 \cdot 121.9$ & $\begin{array}{c}\text { Inject.;11/82 } \\
\text { Withdr;;11/82 }\end{array}$ & $\begin{array}{l}0.46 \\
0.48\end{array}$ & $\begin{array}{l}19 \\
17\end{array}$ & $\begin{array}{r}7 \\
.7\end{array}$ & $\begin{array}{l}\text { 48-hr test; } \\
5 / 82\end{array}$ & 19.2 & $\begin{array}{c}3.0 \\
\text { (drawdown) } \\
22 \\
\text { (recovery) }\end{array}$ & $\begin{array}{c}3.7 \\
\text { (Ina) }\end{array}$ & 3.7 & $\begin{array}{l}\text { Graham } \\
\text { et al. } \\
\text { (1984); } \\
\text { PNL Files }\end{array}$ & $\begin{array}{l}\text { Best est. } \\
\text { based on } \\
\text { constant } \\
\text { discharge } \\
\text { test } \\
\text { drawdown } \\
\end{array}$ \\
\hline 299-E33-12 & $\begin{array}{l}\text { Rattlesnake } \\
\text { Ridge } \\
\text { Interibed }\end{array}$ & $85.3 \cdot 126.5$ & $\begin{array}{c}\text { Inject.;11/82 } \\
\text { Withdr;;11/82 }\end{array}$ & $\begin{array}{l}0.80 \\
0.84\end{array}$ & $\begin{array}{l}12 \\
12\end{array}$ & $\begin{array}{l}12 \\
12\end{array}$ & $\begin{array}{c}48 \cdot h r \\
\text { test; } 5 / 82\end{array}$ & 21.0 & $\begin{array}{c}2.8 \\
\text { (drawdown) } \\
4.2 \\
\text { (recovery) }\end{array}$ & $\begin{array}{l}3.2 \\
3.6\end{array}$ & 3.6 & $\begin{array}{l}\text { Graham } \\
\text { et al. } \\
\text { (1984); } \\
\text { PNL Files }\end{array}$ & $\begin{array}{l}\text { Best est. } \\
\text { based on } \\
\text { constant } \\
\text { discharge } \\
\text { test recovery }\end{array}$ \\
\hline $399-5-2$ & $\begin{array}{c}\text { Composite } \\
\text { Upper } \\
\text { Saddle Mts. } \\
\text { Basalt }\end{array}$ & $59.4-129.2$ & - & - & - & $\cdot$ & $\begin{array}{c}23.5-\mathrm{hr} \\
\text { test; } 2 / 70 \\
2-\text { hr test; } \\
2 / 70\end{array}$ & $\begin{array}{l}11.4 \\
56.8\end{array}$ & $\begin{array}{c}0.55 \\
\text { (recovery) } \\
0.64 \\
\text { (recovery) }\end{array}$ & $\begin{array}{l}1.6 \\
2.2\end{array}$ & 1.9 & PNL Files & $\begin{array}{l}\text { Best est. } \\
\text { based on } \\
\text { constant } \\
\text { discharge } \\
\text { test recovery } \\
\text { average }\end{array}$ \\
\hline
\end{tabular}


Table A.1. (contd)

\begin{tabular}{|c|c|c|c|c|c|c|c|c|c|c|c|c|c|}
\hline $\begin{array}{l}\text { Ilanford Well } \\
\text { Designation }\end{array}$ & $\begin{array}{l}\text { Principal } \\
\text { Hydro- } \\
\text { geologic } \\
\text { Unit }\end{array}$ & $\begin{array}{c}\text { Test Interval } \\
\text { (m) }\end{array}$ & $\begin{array}{l}\text { Slug Test } \\
\text { Type/Date }\end{array}$ & $\begin{array}{c}\text { Slug } \\
\text { Test } \\
\text { Stress } \\
\text { Level } \\
\text { (m-water) }\end{array}$ & $\begin{array}{l}\text { Reported } \\
\text { Trans- } \\
\text { missivity } \\
\left(\mathrm{m}^{2} / \mathrm{d}\right)\end{array}$ & $\begin{array}{c}\text { Reanalysis } \\
\text { Value } \\
\left(\mathrm{m}^{2} / \mathrm{d}\right)\end{array}$ & $\begin{array}{c}\text { Constant } \\
\text { Discharge } \\
\text { Test } \\
\text { Time/Date }\end{array}$ & $\begin{array}{c}\text { Discharge } \\
\text { Rate } \\
\text { (L/min) }\end{array}$ & $\begin{array}{l}\text { Reported } \\
\text { Trans- } \\
\text { missivity } \\
\left(\mathrm{m}^{2} / \mathrm{d}\right)\end{array}$ & $\begin{array}{c}\text { Reanalysis } \\
\text { Value } \\
\left(\mathrm{m}^{2} / \mathrm{d}\right)\end{array}$ & $\begin{array}{c}\text { Best } \\
\text { Estimate } \\
\text { Trans- } \\
\text { missivity } \\
\left(\mathrm{m}^{2} / \mathrm{d}\right)\end{array}$ & $\begin{array}{l}\text { Data } \\
\text { Sources }\end{array}$ & Comments \\
\hline 699-S16-E14* & $\begin{array}{l}\text { Levey } \\
\text { Interbed }\end{array}$ & $83.8 \cdot 104.5$ & - & - & - & - & $\begin{array}{c}\text { 24-hr } \\
\text { test; } 1 / 80 \\
\\
\text { 24-hr air- } \\
\text { lift test; } \\
1 / 80\end{array}$ & 34.8 & $\begin{array}{c}14 \\
\text { (drawdown) } \\
14 \\
\text { (recovery) } \\
11 \\
\text { (recovery) }\end{array}$ & $\begin{array}{l}16 \\
13 \\
9.8\end{array}$ & 13 & $\begin{array}{l}\text { Jackson } \\
\text { and } \\
\text { Spane } \\
\text { (1982); } \\
\text { PNL files. }\end{array}$ & $\begin{array}{l}\text { Best est. } \\
\text { based on } \\
\text { average of } \\
\text { all tests }\end{array}$ \\
\hline 699-S16-E14* & $\begin{array}{l}\text { Rattlesnake } \\
\text { Ridge } \\
\text { Interbed }\end{array}$ & $127.1 \cdot 151.2$ & - & - & - & - & $\begin{array}{c}\text { 24-hr air- } \\
\text { lift test; } \\
1 / 80 \\
\text { 4.S-hr test; } \\
1 / 80\end{array}$ & $\begin{array}{r}227.1 \\
35.6\end{array}$ & $\begin{array}{c}14 \\
\text { (recovery) } \\
17 \\
\text { (recovery) }\end{array}$ & $\begin{array}{l}14 \\
14\end{array}$ & 14 & $\begin{array}{l}\text { Jackson } \\
\text { and } \\
\text { Spane } \\
\text { (1982); } \\
\text { PNL files }\end{array}$ & $\begin{array}{l}\text { Best est. } \\
\text { based on } \\
\text { constant } \\
\text { discharge } \\
\text { test recovery }\end{array}$ \\
\hline 699-S11-E12A & $\begin{array}{c}\text { Levey } \\
\text { Interbed }\end{array}$ & $70.1-79.1$ & $\begin{array}{l}\text { (3) Withdr.; } \\
3 / 80\end{array}$ & $\begin{array}{l}2.91 \\
2.12 \\
0.35\end{array}$ & $\begin{array}{l}1.2 \\
1.2 \\
1.2\end{array}$ & $\dot{.}$ & $\begin{array}{c}\text { 3-hr } \\
\text { constant } \\
\text { drawdown } \\
\text { test; } 3 / 80 \\
21-h r \\
\text { test; } 3 / 80\end{array}$ & $\begin{array}{c}8.3 \text { to } 5.0 \\
3.4\end{array}$ & $\begin{array}{c}1.4 \\
\text { (drawdown) } \\
1.8 \\
\text { (recovery) }\end{array}$ & - & 1.8 & $\begin{array}{l}\text { Spane } \\
\text { (1981) }\end{array}$ & $\begin{array}{l}\text { No test data } \\
\text { available; } \\
\text { analytical } \\
\text { results are } \\
\text { acceptable }\end{array}$ \\
\hline 699-13.1C & $\begin{array}{c}\text { Composite } \\
\text { Upper } \\
\text { Saddle Mis. } \\
\text { Basalt }\end{array}$ & $154.2 \cdot 211.8$ & . & - & . & $\cdot$ & $\begin{array}{c}29-h r \\
\text { test; } 7 / 78 \\
25-h t \\
\text { test;11/78 }\end{array}$ & $\begin{array}{l}1703 \\
1041\end{array}$ & $\begin{array}{c}409 \\
\text { (recovery) } \\
900 \\
\text { (recovery) }\end{array}$ & $\begin{array}{c}7.0 \\
\text { (drawdown) } \\
12 \\
\text { (composite) }\end{array}$ & - & $\begin{array}{l}\text { PNL. } \\
\text { Files; } \\
\text { Gephart } \\
\text { et al. } \\
\text { (1979) }\end{array}$ & $\begin{array}{l}\text { Test analysis } \\
\text { results } \\
\text { highly } \\
\text { uncertain }\end{array}$ \\
\hline 699-14-E6P* & $\begin{array}{l}\text { Rattlesnake } \\
\text { Ridge } \\
\text { Interbed }\end{array}$ & $146.3 \cdot 154.5$ & - & - & - & - & $\begin{array}{c}2.3-h r \text { test; } \\
2 / 70\end{array}$ & 56.8 & $\begin{array}{c}61 \\
\text { (recovery) }\end{array}$ & 64 & 64 & $\begin{array}{l}\text { Deju } \\
\text { (1974); } \\
\text { PNL Files }\end{array}$ & $\begin{array}{l}\text { Best est. } \\
\text { based on } \\
\text { constant } \\
\text { discharge } \\
\text { test recovery }\end{array}$ \\
\hline $699-17-47^{\circ}$ & $\begin{array}{l}\text { Elephant } \\
\text { Mt. } \\
\text { Interfow }\end{array}$ & $113.4 \cdot 125.3$ & - & - & - & - & $\begin{array}{l}24-\mathrm{hr} \\
\text { test (?); } \\
1978\end{array}$ & (?) & 569 & - & 569 & $\begin{array}{l}\text { Gephart } \\
\text { et al. } \\
\text { (1979) }\end{array}$ & $\begin{array}{l}\text { No test data } \\
\text { available; } \\
\text { reliability of } \\
\text { analytical } \\
\text { results } \\
\text { uncertain }\end{array}$ \\
\hline
\end{tabular}


Table A.1. (contd)

\begin{tabular}{|c|c|c|c|c|c|c|c|c|c|c|c|c|c|}
\hline $\begin{array}{c}\text { Hanford Well } \\
\text { Designation }\end{array}$ & $\begin{array}{c}\text { Principal } \\
\text { Hydro- } \\
\text { geologic } \\
\text { Unit }\end{array}$ & $\begin{array}{l}\text { Test Interval } \\
(\mathrm{m})\end{array}$ & $\begin{array}{l}\text { Slug Test } \\
\text { Type/Date }\end{array}$ & $\begin{array}{c}\text { Slug } \\
\text { Test } \\
\text { Stress } \\
\text { Level } \\
\text { (m-water) }\end{array}$ & $\begin{array}{l}\text { Reported } \\
\text { Trans- } \\
\text { missivity } \\
\left(\mathrm{m}^{2} / \mathrm{d}\right)\end{array}$ & $\begin{array}{c}\text { Reanalysis } \\
\text { Value } \\
\left(\mathrm{m}^{2} / \mathrm{d}\right)\end{array}$ & $\begin{array}{l}\text { Constant } \\
\text { Discharge } \\
\text { Test } \\
\text { Time/Date }\end{array}$ & $\begin{array}{l}\text { Discharge } \\
\text { Rate } \\
\text { (1/ } / \mathrm{min})\end{array}$ & $\begin{array}{l}\text { Reported } \\
\text { Trans- } \\
\text { missivity } \\
\left(\mathrm{m}^{2} / \mathrm{d}\right)\end{array}$ & $\begin{array}{c}\text { Reanalysis } \\
\text { Value } \\
\left(\mathrm{m}^{2} / \mathrm{d}\right)\end{array}$ & $\begin{array}{c}\text { Best } \\
\text { Estimate } \\
\text { Trans- } \\
\text { missivity } \\
\left(\mathrm{m}^{2} / \mathrm{d}\right)\end{array}$ & $\begin{array}{c}\text { Data } \\
\text { Sources }\end{array}$ & Comments \\
\hline $699-17-47^{*}$ & $\begin{array}{l}\text { Ratulesnake } \\
\text { Ridge } \\
\text { Interbed }\end{array}$ & $140.8-165.8$ & - & - & - & - & $\begin{array}{c}24-\mathrm{hr} \\
\text { test (?); } \\
\text { 1978 }\end{array}$ & (?) & 28 & . & 28 & $\begin{array}{l}\text { Gephart } \\
\text { et al. } \\
\text { (1979) }\end{array}$ & $\begin{array}{l}\text { No test data } \\
\text { availabble; } \\
\text { reliability of } \\
\text { analytical } \\
\text { results } \\
\text { uncertain }\end{array}$ \\
\hline 699-24-1P & $\begin{array}{c}\text { Ringold } \\
\text { Formation/ } \\
\text { Elephant } \\
\text { Mt. Basalt }\end{array}$ & $132.6-163.7$ & & - & - & - & $\begin{array}{c}5.2-\mathrm{hr} \\
\text { test } ; 3 / 70\end{array}$ & 30.3 & $\begin{array}{c}8.1 \\
\text { (recovery) }\end{array}$ & 8.1 & 8.1 & $\begin{array}{l}\text { Deju } \\
\text { (1974); } \\
\text { PNL Files }\end{array}$ & $\begin{array}{l}\text { Test interval } \\
\text { includes } \\
\text { overlying } \\
\text { Ringold } \\
\text { Formation }\end{array}$ \\
\hline $699-255-80^{*}$ & $\begin{array}{c}\text { Ratillesnake } \\
\text { Ridge } \\
\text { Interbed }\end{array}$ & $64.0 \cdot 87.8$ & - & . & - & - & $\begin{array}{c}\text { 4e.8-hr } \\
\text { test; } 9 / 78\end{array}$ & 37.1 & $\begin{array}{c}0.82 \\
\text { (drawdown) } \\
1.1 \\
\text { (recovery) }\end{array}$ & $\begin{array}{l}0.43 \\
0.37\end{array}$ & 0.40 & $\begin{array}{l}\text { Spane et } \\
\text { al. (1980) }\end{array}$ & $\begin{array}{l}\text { Best est. } \\
\text { bassd on } \\
\text { constant } \\
\text { discharge } \\
\text { test average }\end{array}$ \\
\hline 699-31-84A & $\begin{array}{l}\text { Rattlesnake } \\
\text { Ridge } \\
\text { Interbed }\end{array}$ & $203.6 \cdot 254.5$ & - & . & - & - & $\begin{array}{c}\text { 24-hr test; } \\
\text { 9/81 }\end{array}$ & 315 & $\begin{array}{c}138 \\
\text { (drawdown) } \\
\text { 208 } \\
\text { (recovery) }\end{array}$ & $\begin{array}{l}62 \\
67\end{array}$ & 65 & $\begin{array}{l}\text { Strait and } \\
\text { Bruce } \\
\text { (1981); } \\
\text { PNL Files }\end{array}$ & $\begin{array}{l}\text { Best est. } \\
\text { bassed on } \\
\text { constant } \\
\text { discharge } \\
\text { test average }\end{array}$ \\
\hline 699-32-22. & $\begin{array}{l}\text { Elephant } \\
\text { Mt. } \\
\text { Interflow }\end{array}$ & $232.0-256.0$ & $\begin{array}{l}\text { Inject:5/9/1 } \\
\text { Withdr:;/91 }\end{array}$ & $\begin{array}{l}0.45 \\
0.39\end{array}$ & $\begin{array}{l}1.4 \\
1.4\end{array}$ & - & $\begin{array}{c}10-\mathrm{hr} \\
\text { Iest; } 6 / 91\end{array}$ & 50.7 & $\begin{array}{c}3.2 \\
\text { (drawdown) } \\
4.7 \\
\text { (recovery) }\end{array}$ & - & 4.7 & $\begin{array}{l}\text { Spance } \\
\text { (1992) }\end{array}$ & $\begin{array}{l}\text { Previously } \\
\text { reported } \\
\text { values are } \\
\text { acceptable }\end{array}$ \\
\hline 699-42-E9B & $\begin{array}{l}\text { Elephant } \\
\text { Mt. } \\
\text { Interflow }\end{array}$ & $70.7-86.9$ & Withdr;/91 & 0.42 & 102 & . & $\begin{array}{c}17.5-\mathrm{hr} \\
\text { test } ; 3 / 91\end{array}$ & 158.2 & 64 & - & 64 & $\begin{array}{l}\text { Spane } \\
(1992)\end{array}$ & $\begin{array}{l}\text { Previously } \\
\text { reported } \\
\text { values are } \\
\text { acceptable }\end{array}$ \\
\hline 699-42-E9B & $\begin{array}{l}\text { Elephant } \\
\text { Mt./ } \\
\text { Pomona } \\
\text { Flow } \\
\text { Contact }\end{array}$ & $107.9 \cdot 118.6$ & - & & - & . & $\begin{array}{c}\text { 11-hr } \\
\text { test; } 4 / 91\end{array}$ & 147.8 & $\begin{array}{c}28 \\
\text { (drawdown) } \\
34 \\
\text { (recovery) }\end{array}$ & . & 28 & $\begin{array}{l}\text { Spane } \\
\text { (1992) }\end{array}$ & $\begin{array}{l}\text { Previously } \\
\text { reported } \\
\text { values are } \\
\text { acceptable }\end{array}$ \\
\hline
\end{tabular}


Table A.1. (contd)

\begin{tabular}{|c|c|c|c|c|c|c|c|c|c|c|c|c|c|}
\hline $\begin{array}{l}\text { Hanford Well } \\
\text { Designation }\end{array}$ & $\begin{array}{l}\text { Principal } \\
\text { Hydro- } \\
\text { geologic } \\
\text { Unit }\end{array}$ & $\begin{array}{l}\text { Test Interval } \\
(\mathrm{m})\end{array}$ & $\begin{array}{c}\text { Slug Test } \\
\text { Type/Date }\end{array}$ & $\begin{array}{c}\text { Slug } \\
\text { Test } \\
\text { Stress } \\
\text { level } \\
\text { (m-water) }\end{array}$ & $\begin{array}{l}\text { Reported } \\
\text { Trans- } \\
\text { missivity } \\
\left(\mathrm{m}^{2} / \mathrm{d}\right)\end{array}$ & $\begin{array}{c}\text { Reanalysis } \\
\text { Value } \\
\left(\mathrm{m}^{2} / \mathrm{d}\right)\end{array}$ & $\begin{array}{l}\text { Constant } \\
\text { Discharge } \\
\text { Test } \\
\text { Time/Date }\end{array}$ & $\begin{array}{l}\text { Discharge } \\
\text { Rate } \\
\text { (L/min) }\end{array}$ & $\begin{array}{l}\text { Reported } \\
\text { Trans- } \\
\text { missivity } \\
\left(\mathrm{m}^{2} / \mathrm{d}\right)\end{array}$ & $\begin{array}{c}\text { Reanalysis } \\
\text { Value } \\
\left(\mathrm{m}^{2} / d\right)\end{array}$ & $\begin{array}{c}\text { Best } \\
\text { Estimate } \\
\text { Trans- } \\
\text { missivity } \\
\left(\mathrm{m}^{2} / \mathrm{d}\right)\end{array}$ & $\begin{array}{c}\text { Data } \\
\text { Sources }\end{array}$ & Comments \\
\hline $699-42-40 \mathrm{C}$ & $\begin{array}{l}\text { Elephant } \\
\text { Mt. } \\
\text { Interflow }\end{array}$ & $?$ & $\cdot$ & - & - & - & $\begin{array}{c}22.9-\mathrm{hr} \\
\text { test; } 4 / 82\end{array}$ & 7.1 & $\begin{array}{c}0.7 \\
\text { (drawdown) }\end{array}$ & 0.9 & 0.9 & $\begin{array}{l}\text { Graham } \\
\text { et al. } \\
\text { (1984); } \\
\text { PNL Files }\end{array}$ & $\begin{array}{l}\text { Best est. } \\
\text { based on } \\
\text { constant } \\
\text { discharge } \\
\text { test } \\
\text { drawdown }\end{array}$ \\
\hline $699-42-40 \mathrm{C}$ & $\begin{array}{c}\text { Rattlesnake } \\
\text { Ridge. } \\
\text { Interbed }\end{array}$ & $96.6 \cdot 118.9$ & $\begin{array}{l}\text { Inject;:10/82 } \\
\text { Withdr:;10/82 }\end{array}$ & $\begin{array}{l}0.39 \\
0.49\end{array}$ & $\begin{array}{l}85 \\
87\end{array}$ & $\begin{array}{c}\text { (na) } \\
45\end{array}$ & $\begin{array}{c}\text { 24-hr } \\
\text { test; } 11 / 82\end{array}$ & 28.0 & $\begin{array}{c}28 \\
\text { (drawdown) } \\
16 \\
\text { (recovery) }\end{array}$ & $\begin{array}{l}40 \\
30\end{array}$ & 40 & $\begin{array}{l}\text { Graham } \\
\text { ei al. } \\
\text { (1984); } \\
\text { PNL Files }\end{array}$ & $\begin{array}{l}\text { Best est. } \\
\text { based on } \\
\text { constant } \\
\text { discharge } \\
\text { test } \\
\text { drawdown }\end{array}$ \\
\hline $699-47-42^{*}$ & $\begin{array}{l}\text { Rattlesnake } \\
\text { Ridge } \\
\text { Interbed }\end{array}$ & $45.7 \cdot 67.7$ & - & - & - & - & $\begin{array}{c}\text { 12.7-hr air- } \\
\text { lift test; } \\
4 / 79 \\
4.5-\mathrm{hr} \text { test; } \\
4 / 79 \\
\end{array}$ & $\begin{array}{l}86.7 \\
32.3\end{array}$ & $\begin{array}{c}44 \\
\text { (recovery) } \\
46 \\
\text { (drawdown) } \\
\end{array}$ & $\begin{array}{l}25 \\
30\end{array}$ & 28 & $\begin{array}{l}\text { Strait and } \\
\text { Brown } \\
\text { (1983); } \\
\text { PNL Files }\end{array}$ & $\begin{array}{l}\text { Best cst. } \\
\text { based on } \\
\text { average for } \\
\text { both tests }\end{array}$ \\
\hline $699-47-50$ & $\begin{array}{l}\text { Rartlesnake } \\
\text { Ridge } \\
\text { Interbed }\end{array}$ & $79.2-89.9$ & $\begin{array}{l}\text { Inject:;11/82 } \\
\text { Withdr;;11/82 }\end{array}$ & $\begin{array}{l}0.79 \\
0.83\end{array}$ & $\begin{array}{l}33 \\
31\end{array}$ & $\begin{array}{l}\text { (na) } \\
11\end{array}$ & $\begin{array}{c}12-\mathrm{hr} \\
\text { test; } 6 / 80\end{array}$ & 21.5 & $\begin{array}{c}43 \\
\text { (drawdown) } \\
93 \\
\text { (recovery) }\end{array}$ & $\begin{array}{c}23 \\
\text { (Ina) }\end{array}$ & 23 & $\begin{array}{l}\text { Strait and } \\
\text { Moore } \\
\text { (1982); } \\
\text { Graham } \\
\text { ct al. } \\
\text { (1984) }\end{array}$ & $\begin{array}{l}\text { Best est. } \\
\text { based on } \\
\text { constant } \\
\text { discharge } \\
\text { test } \\
\text { drawdown }\end{array}$ \\
\hline 699-49-55B & $\begin{array}{l}\text { Rattlesnake } \\
\text { Ridge } \\
\text { Interbed }\end{array}$ & $53.3 \cdot 68.9$ & $\begin{array}{l}\text { Inject;111/82 } \\
\text { Withdr;;11/82 }\end{array}$ & $\begin{array}{l}0.31 \\
0.45\end{array}$ & $\begin{array}{l}182 \\
106\end{array}$ & $\begin{array}{c}\text { (na) } \\
110\end{array}$ & $\begin{array}{c}\begin{array}{c}46 \cdot h r \\
\text { rest:5/82 }\end{array}\end{array}$ & 115.8 & $\begin{array}{c}70 \\
\text { (drawdown) } \\
73 \\
\text { (recovery) }\end{array}$ & $\begin{array}{l}61 \\
72\end{array}$ & 72 & $\begin{array}{l}\text { Graham } \\
\text { et al. } \\
\text { (1984); } \\
\text { PNL. Files }\end{array}$ & $\begin{array}{l}\text { Best est. } \\
\text { based on } \\
\text { constant } \\
\text { discharge } \\
\text { test recovery }\end{array}$ \\
\hline 699-49-57B & $\begin{array}{l}\text { Rattlesnake } \\
\text { Ridge } \\
\text { Interbed }\end{array}$ & $63.7-68.4$ & - & - & - & - & $\begin{array}{c}3.4 \cdot \mathrm{hr} \\
\text { test; } 1 / 92\end{array}$ & 44.7 & 14 & 14 & 14 & $\begin{array}{l}\text { Swanson } \\
\text { (1992) }\end{array}$ & $\begin{array}{l}\text { Best est. } \\
\text { based on } \\
\text { constant } \\
\text { discharge } \\
\text { test } \\
\text { drawdown }\end{array}$ \\
\hline
\end{tabular}


Table A.1. (contd)

\begin{tabular}{|c|c|c|c|c|c|c|c|c|c|c|c|c|c|}
\hline $\begin{array}{c}\text { Hanford Well } \\
\text { Designation }\end{array}$ & $\begin{array}{c}\text { Principal } \\
\text { Iydro- } \\
\text { geologic } \\
\text { Unit } \\
\end{array}$ & $\begin{array}{c}\text { Test Interval } \\
(m)\end{array}$ & $\begin{array}{c}\text { Slug Test } \\
\text { Type/Date }\end{array}$ & $\begin{array}{c}\text { Slug } \\
\text { Test } \\
\text { Stress } \\
\text { level } \\
\text { (m-water) } \\
\end{array}$ & $\begin{array}{c}\text { Reporied } \\
\text { Trans- } \\
\text { missivity } \\
\left(\mathrm{m}^{2} / \mathrm{d}\right) \\
\end{array}$ & $\begin{array}{c}\text { Reanalysis } \\
\text { Value } \\
\left(\mathrm{m}^{2} / \mathrm{d}\right)\end{array}$ & $\begin{array}{l}\text { Constant } \\
\text { Discharge } \\
\text { Test } \\
\text { Time/Date }\end{array}$ & $\begin{array}{c}\text { Discharge } \\
\text { Rate } \\
\text { (L/min) }\end{array}$ & $\begin{array}{l}\text { Reported } \\
\text { Trans- } \\
\text { missivity } \\
\left(m^{2} / d\right)\end{array}$ & $\begin{array}{c}\text { Reanalysis } \\
\text { Value } \\
\left(\mathrm{m}^{2} / \mathrm{d}\right)\end{array}$ & $\begin{array}{l}\text { Best } \\
\text { Estimate } \\
\text { Trans- } \\
\text { missivity } \\
\left(\mathrm{m}^{2} / \mathrm{d}\right)\end{array}$ & $\begin{array}{c}\text { Data } \\
\text { Sources }\end{array}$ & Comments \\
\hline $699-50-45$ & $\begin{array}{c}\text { Rattlesnake } \\
\text { Ridge } \\
\text { Interted }\end{array}$ & $40.5-54.3$ & $\begin{array}{l}\text { Inject.;11/82 } \\
\text { Withdr:;11/82 }\end{array}$ & $\begin{array}{l}0.80 \\
0.81\end{array}$ & $\begin{array}{r}5 \\
5\end{array}$ & $\begin{array}{l}4.8 \\
6.0\end{array}$ & $\begin{array}{c}21-h r \\
\text { test: } 5 / 80\end{array}$ & 32.0 & $\begin{array}{c}12 \\
\text { (drawdown) } \\
16 \\
\text { (recovery) }\end{array}$ & $\begin{array}{l}16 \\
15\end{array}$ & 16 & $\begin{array}{l}\text { Sirait and } \\
\text { Moore } \\
\text { (1982); } \\
\text { Graham } \\
\text { et al. } \\
\text { (1984) } \\
\end{array}$ & $\begin{array}{l}\text { Best est. } \\
\text { based on } \\
\text { constant } \\
\text { discharge } \\
\text { test } \\
\text { drawdown } \\
\end{array}$ \\
\hline $699-50-48 B$ & $\begin{array}{c}\text { Rattlesnake } \\
\text { Ridge } \\
\text { Interbed }\end{array}$ & $64.9-76.2$ & $\begin{array}{l}\text { Inject::11/82 } \\
\text { Withdr:;11/82 }\end{array}$ & $\begin{array}{l}0.77 \\
0.84\end{array}$ & $\begin{array}{l}18 \\
11\end{array}$ & $\stackrel{(\text { tna })}{30}$ & $\begin{array}{c}18.5-\mathrm{hr} \\
\text { test } 6 / 80\end{array}$ & 26.3 & $\begin{array}{c}34 \\
\text { (drawdown) } \\
26 \\
\text { (recovery) }\end{array}$ & $\begin{array}{c}21 \\
\text { (Ina) }\end{array}$ & 21 & $\begin{array}{l}\text { Strait and } \\
\text { Moore } \\
\text { (1982); } \\
\text { Graham } \\
\text { et al. } \\
\text { (1984) } \\
\end{array}$ & $\begin{array}{l}\text { Best est. } \\
\text { based on } \\
\text { constant } \\
\text { discharge } \\
\text { test }\end{array}$ \\
\hline $699-51-46$ & $\begin{array}{c}\text { Rattlessake } \\
\text { Ridge } \\
\text { Interted }\end{array}$ & $36.6-51.2$ & $\begin{array}{l}\text { Inject.:11/82 } \\
\text { Withdr:;11/82 }\end{array}$ & $\begin{array}{l}0.47 \\
0.49\end{array}$ & $\begin{array}{l}2.0 \\
0.3\end{array}$ & $\begin{array}{c}0.9 \\
\text { (na) }\end{array}$ & $\underset{\text { test; } 5 / 80}{21 / h r}$ & 10.2 & $\begin{array}{c}30 \\
\text { (drawdown) } \\
10 \\
\text { (recovery) }\end{array}$ & $\begin{array}{l}3.1 \\
\text { (tna) }\end{array}$ & 3.1 & $\begin{array}{l}\text { Strait and } \\
\text { Moore } \\
\text { (1982); } \\
\text { Graham } \\
\text { et al. } \\
\text { (1984) } \\
\end{array}$ & $\begin{array}{l}\text { Best est. } \\
\text { based on } \\
\text { constant } \\
\text { discharge } \\
\text { test } \\
\text { drawdown }\end{array}$ \\
\hline $699.52-46 \mathrm{~A}$ & $\begin{array}{l}\text { Ratulesnake } \\
\text { Ridge } \\
\text { Interted }\end{array}$ & $53.3 \cdot 68.6$ & $\begin{array}{l}\text { Inject.;11/82 } \\
\text { Withdr:;11/82 }\end{array}$ & $\begin{array}{l}0.39 \\
0.43\end{array}$ & $\begin{array}{l}21 \\
18\end{array}$ & $\begin{array}{l}19 \\
28\end{array}$ & $\begin{array}{c}20.7-\mathrm{hr} \\
\text { test; } 5 / 80\end{array}$ & 178.3 & $\begin{array}{c}17 \\
\text { (drawdown) } \\
13 \\
\text { (recovery) }\end{array}$ & $\begin{array}{l}18 \\
16\end{array}$ & 20 & $\begin{array}{l}\text { Strait and } \\
\text { Moore } \\
\text { (1982); } \\
\text { Graham } \\
\text { te al. } \\
\text { (1984) }\end{array}$ & $\begin{array}{l}\text { Best est. } \\
\text { based on } \\
\text { average of } \\
\text { all tesests }\end{array}$ \\
\hline $699.52-48$ & $\begin{array}{c}\text { Rattlessake } \\
\text { Ridge } \\
\text { Interbed }\end{array}$ & $45.4-59.4$ & $\begin{array}{c}\text { Inject.;11/82 } \\
\text { Withdr:;11/82 }\end{array}$ & $\begin{array}{l}0.44 \\
0.40\end{array}$ & $\begin{array}{l}11 \\
5.1\end{array}$ & $\begin{array}{l}7.0 \\
9.0\end{array}$ & $\begin{array}{c}\text { 14-hr } \\
\text { Iest; } 4 / 80\end{array}$ & 30.5 & $\begin{array}{c}3.5 \\
\text { (drawdown) } \\
3.4 \\
\text { (recovery) }\end{array}$ & $\begin{array}{l}3.5 \\
3.3\end{array}$ & 3.4 & $\begin{array}{l}\text { Strait and } \\
\text { Moore } \\
\text { (1982); } \\
\text { Graham } \\
\text { et at. } \\
\text { (1984) } \\
\end{array}$ & $\begin{array}{l}\text { Best est. } \\
\text { based on } \\
\text { constant } \\
\text { discharge } \\
\text { test results }\end{array}$ \\
\hline $699.53-50$ & $\begin{array}{c}\text { Rautlessnake } \\
\text { Ridge } \\
\text { Interbed }\end{array}$ & $44.2-59.1$ & $\begin{array}{l}\text { Inject:;11/82 } \\
\text { Withdr:;11/82 }\end{array}$ & $\begin{array}{l}0.44 \\
0.49\end{array}$ & $\begin{array}{l}74 \\
85\end{array}$ & $\begin{array}{l}30 \\
32\end{array}$ & $\begin{array}{c}18.7 \cdot \mathrm{hr} \\
\text { test; } 4 / 80\end{array}$ & 26.1 & $\begin{array}{c}50 \\
\text { (drawdown) } \\
60 \\
\text { (recovery) }\end{array}$ & $\begin{array}{c}50 \\
\text { (tna) }\end{array}$ & so & $\begin{array}{l}\text { Strait and } \\
\text { Moorce } \\
\text { (1982); } \\
\text { Graham } \\
\text { et al. } \\
\text { (1984) }\end{array}$ & $\begin{array}{l}\text { Best est. } \\
\text { based on } \\
\text { constant } \\
\text { discharge } \\
\text { test } \\
\text { drawdown }\end{array}$ \\
\hline
\end{tabular}


Table A.1. (contd)

\begin{tabular}{|c|c|c|c|c|c|c|c|c|c|c|c|c|c|}
\hline $\begin{array}{l}\text { Hanford Well } \\
\text { Designation }\end{array}$ & $\begin{array}{l}\text { Principal } \\
\text { Hydro- } \\
\text { geologic } \\
\text { Unit }\end{array}$ & $\begin{array}{l}\text { Test Interval } \\
(\mathrm{m})\end{array}$ & $\begin{array}{c}\text { Slug Test } \\
\text { Type/Date }\end{array}$ & $\begin{array}{c}\text { Slug } \\
\text { Test } \\
\text { Stress } \\
\text { Level } \\
\text { (m-water) }\end{array}$ & $\begin{array}{c}\text { Reporeded } \\
\text { Trans- } \\
\text { missivity } \\
\left(\mathrm{m}^{2} / \mathrm{d}\right) \\
\end{array}$ & $\begin{array}{c}\text { Reanalysis } \\
\text { Valuc } \\
\left(\mathrm{m}^{2} / \mathrm{d}\right)\end{array}$ & $\begin{array}{c}\text { Constant } \\
\text { Discharge } \\
\text { Test } \\
\text { Time/Date }\end{array}$ & $\begin{array}{c}\text { Discharge } \\
\text { Rate } \\
\text { (L/min) }\end{array}$ & $\begin{array}{c}\text { Reported } \\
\text { Trans- } \\
\text { missivity } \\
\left(\mathrm{m}^{2} / \mathrm{d}\right) \\
\end{array}$ & $\begin{array}{c}\text { Reanalysis } \\
\text { Value } \\
\left(\mathrm{m}^{2} / \mathrm{d}\right)\end{array}$ & $\begin{array}{c}\text { Best } \\
\text { Estimate } \\
\text { Trans- } \\
\text { missivity } \\
\left(\mathrm{m}^{2} / \mathrm{d}\right) \\
\end{array}$ & $\begin{array}{c}\text { Data } \\
\text { Sources } \\
\end{array}$ & Comments \\
\hline 699-54-57 & $\begin{array}{l}\text { Rattlesnake } \\
\text { Ridge } \\
\text { Interbed }\end{array}$ & $74.7 \cdot 97.8$ & $\begin{array}{l}\text { Inject.:11/82 } \\
\text { Withdr:;11/82 }\end{array}$ & $\begin{array}{l}0.72 \\
0.80\end{array}$ & $\begin{array}{l}19 \\
12\end{array}$ & $\begin{array}{c}(\mathrm{tna}) \\
12\end{array}$ & $\begin{array}{c}48-h r \\
\text { test:5/82 }\end{array}$ & 36.9 & $\begin{array}{c}12 \\
\text { (drawdown) } \\
13 \\
\text { (recovery) }\end{array}$ & $\begin{array}{l}12 \\
12\end{array}$ & 12 & $\begin{array}{l}\text { Graham } \\
\text { et al. } \\
\text { (1984); } \\
\text { PNL Files }\end{array}$ & $\begin{array}{l}\text { Best est. } \\
\text { bassed on } \\
\text { constant } \\
\text { discharge } \\
\text { test average }\end{array}$ \\
\hline $699-56-53$ & $\begin{array}{c}\text { Ratulesnake } \\
\text { Ridge } \\
\text { Interbed }\end{array}$ & $61.0-82.3$ & $\begin{array}{c}\text { Inject:;11/82 } \\
\text { Withdr:;11/82 }\end{array}$ & $\begin{array}{l}0.44 \\
0.49\end{array}$ & $\begin{array}{l}36 \\
27\end{array}$ & $\begin{array}{l}25 \\
27\end{array}$ & $\begin{array}{c}37.3-\mathrm{hr} \\
\text { test; } 6 / 82\end{array}$ & 98.0 & $\begin{array}{c}85 \\
\text { (drawdown) } \\
64 \\
\text { (recovery) }\end{array}$ & $\begin{array}{c}\text { (tna) } \\
28\end{array}$ & 27. & $\begin{array}{l}\text { Graham } \\
\text { et at. } \\
\text { (1984); } \\
\text { PNL Files }\end{array}$ & $\begin{array}{l}\text { Best est. } \\
\text { based on } \\
\text { average of } \\
\text { all test }\end{array}$ \\
\hline $699-84-34 \mathrm{~B}^{*}$ & $\begin{array}{l}\text { Elephant } \\
\text { Mt. } \\
\text { Interflow }\end{array}$ & $112.5 \cdot 144.8$ & & & - & - & $\begin{array}{c}\text { 3-hr test; } \\
\text { 1/80 } \\
5.7 . \mathrm{hr} \\
\text { test; 1/80 }\end{array}$ & $\begin{array}{l}30.3 \\
28.2\end{array}$ & $\begin{array}{c}0.39 \\
\text { (recovery) } \\
0.32 \\
\text { (drawdown) } \\
0.52 \\
\text { (recovery) }\end{array}$ & $\begin{array}{l}0.40 \\
0.32 \\
0.45\end{array}$ & 0.39 & $\begin{array}{l}\text { Strait } \\
\text { (1980); } \\
\text { PNL. Files }\end{array}$ & $\begin{array}{l}\text { Best est. } \\
\text { based on } \\
\text { constant } \\
\text { discharge } \\
\text { lest average }\end{array}$ \\
\hline $699-84-34 \mathrm{~B}^{\circ}$ & $\begin{array}{c}\text { Rattlesnake } \\
\text { Ridge } \\
\text { Interted }\end{array}$ & $144.8-164.0$ & - & & - & - & $\begin{array}{c}21-\text { hr test; } \\
1 / 80 \\
\text { 3.5-hr test; } \\
1 / 80\end{array}$ & $\begin{array}{l}42.0 \\
7.8\end{array}$ & $\begin{array}{c}1.9 \\
\text { (recovery) } \\
1.8 \\
\text { (drawdown) } \\
1.5 \\
\text { (recovery) }\end{array}$ & $\begin{array}{c}2.0 \\
\text { (ina) } \\
\text { (tna) }\end{array}$ & 2.0 & $\begin{array}{l}\text { Strait } \\
(1980) ; \\
\text { PNL Files }\end{array}$ & $\begin{array}{l}\text { Short } \\
\text { duration } \\
\text { constant } \\
\text { discharge } \\
\text { test not } \\
\text { analyzable }\end{array}$ \\
\hline
\end{tabular}

- Test well abandoned or recompleted in another hydrogeologic unit. (tna) Test not analyzable. 


\begin{tabular}{||l|l||}
\hline Well/Borehole : $\quad$ 199-B3-2P & Test Interval Depth : $199.6 \mathrm{~m}$ to $237.1 \mathrm{~m}$ \\
\hline Hydrologic Unit : Rattlesnake Ridge Interbed & Test Date(s) : 4/7/70 \\
\hline Reference Document(s) : Deju (1974) - ARH-C-4; PNL Files \\
Test Description: \\
Hydrologic testing for this well test site was limited to a recovery test following a constant-rate \\
air-lift pumping test. The following is a brief description of the testing activities.
\end{tabular}




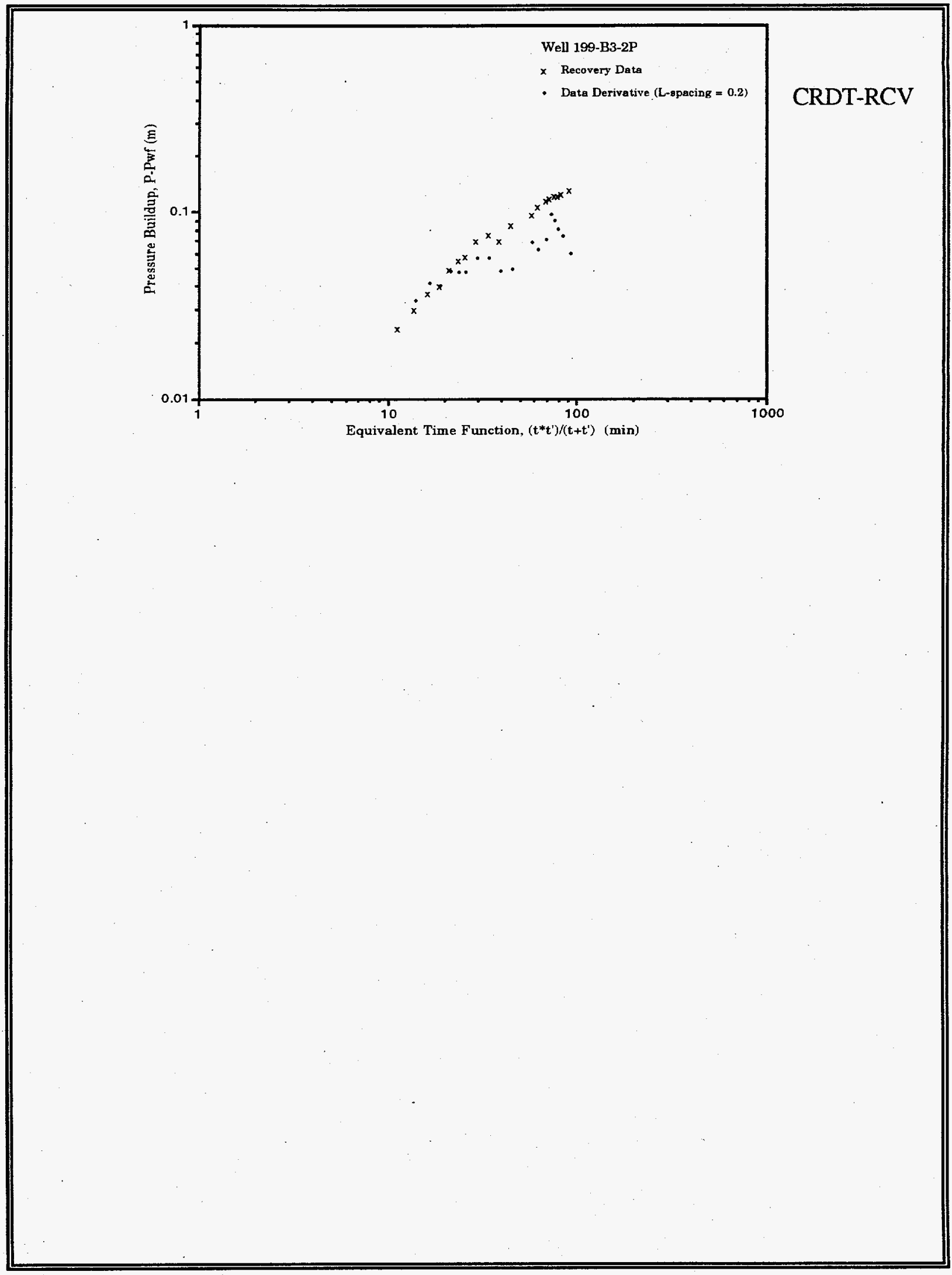

A. 9 


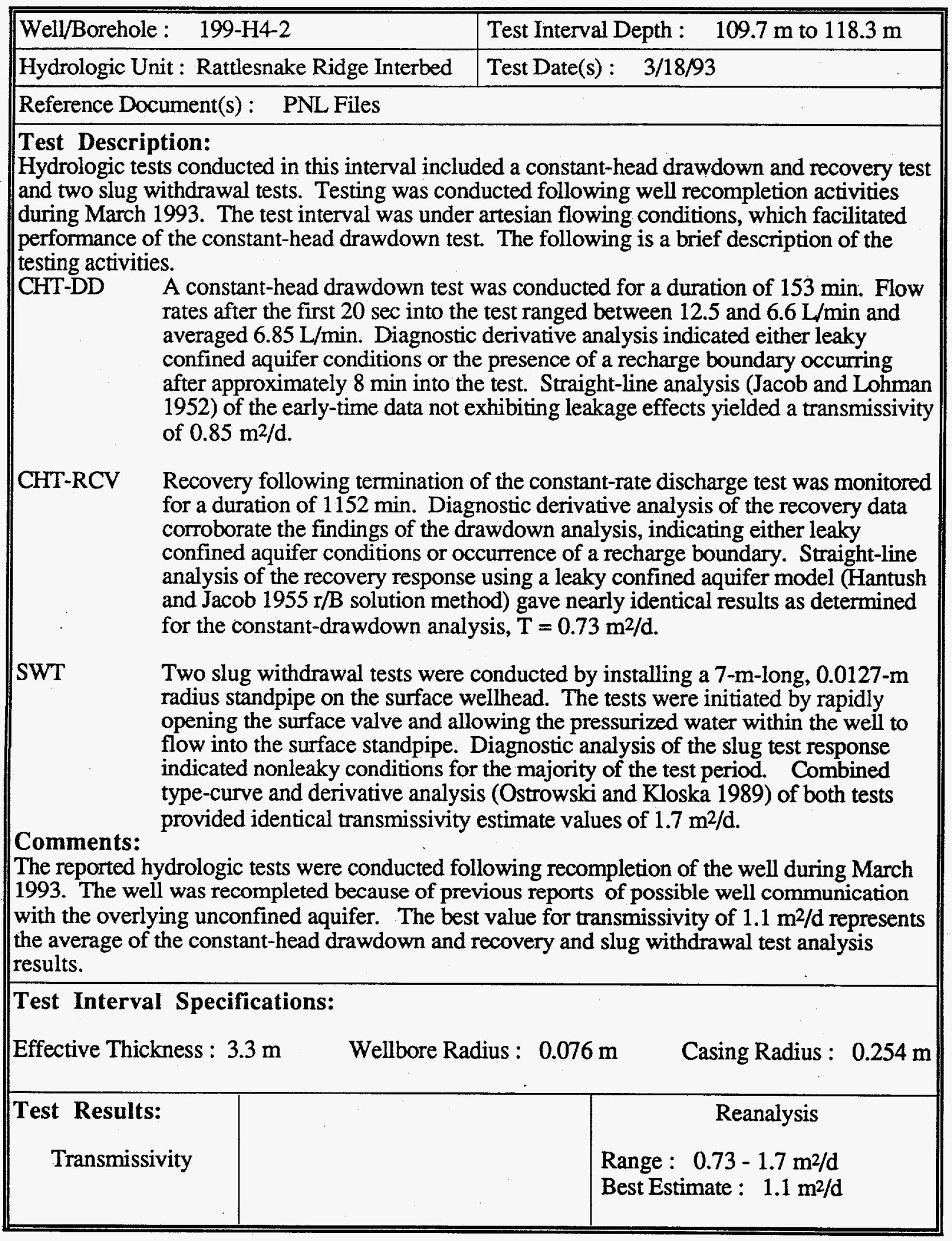




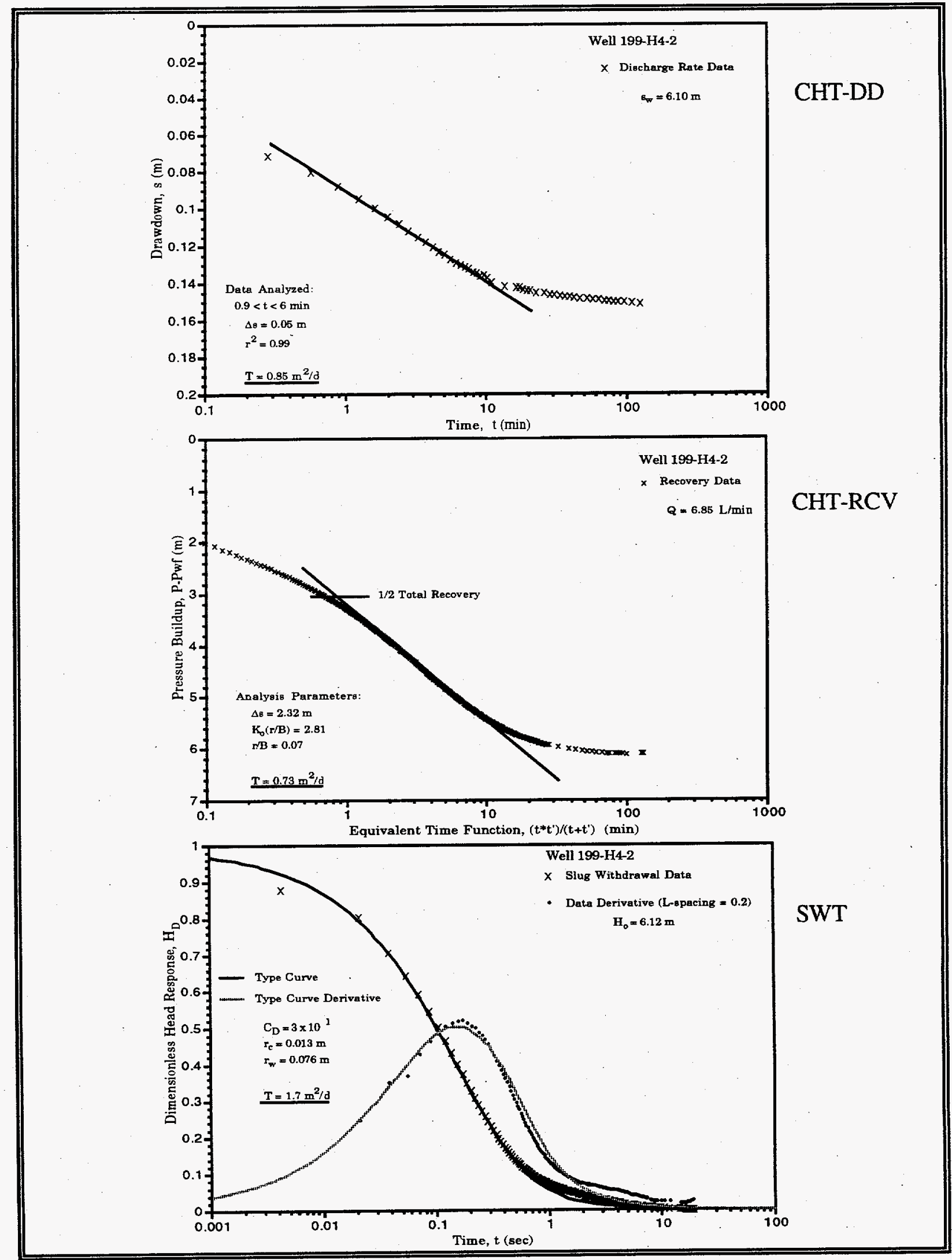

A. 11 


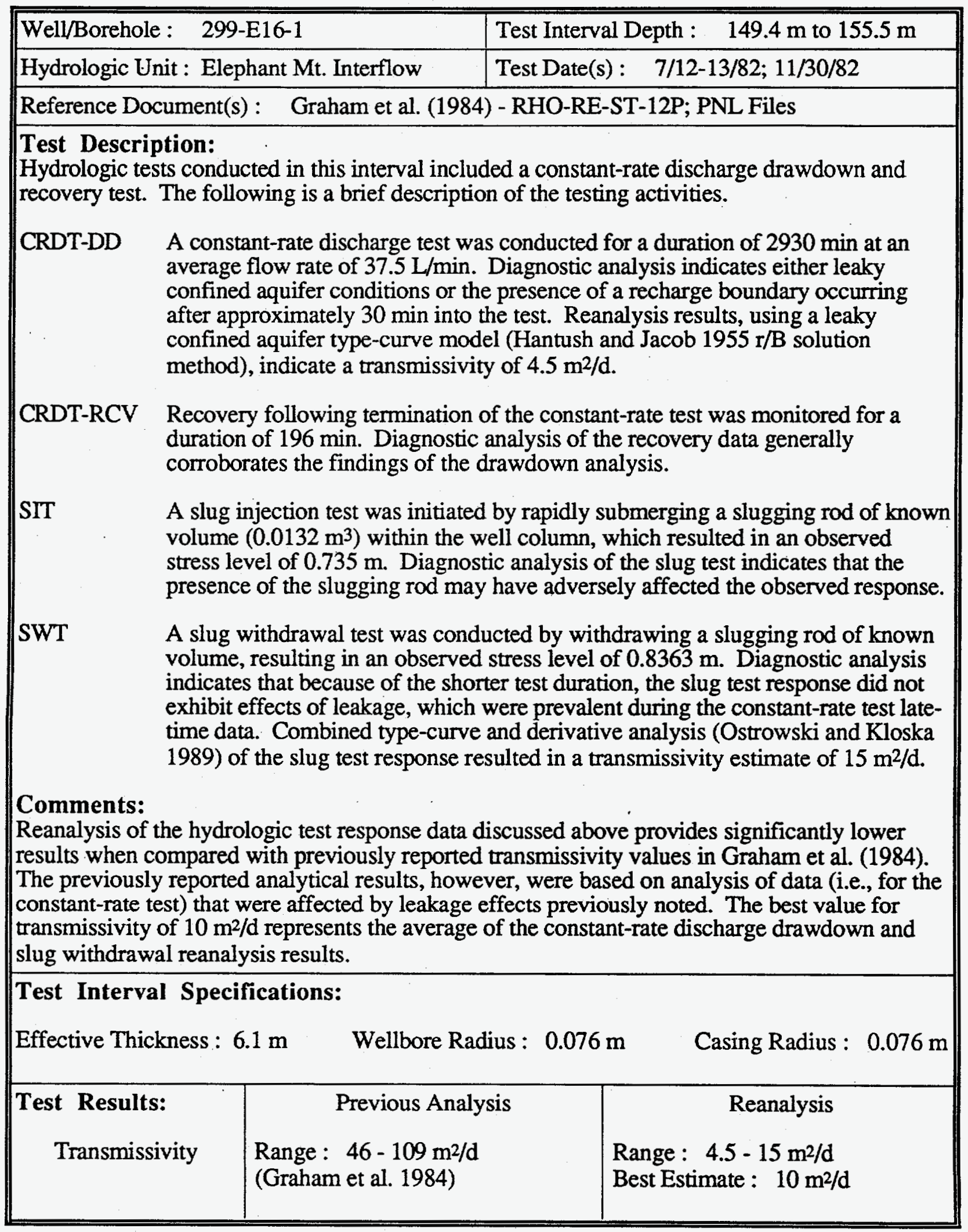




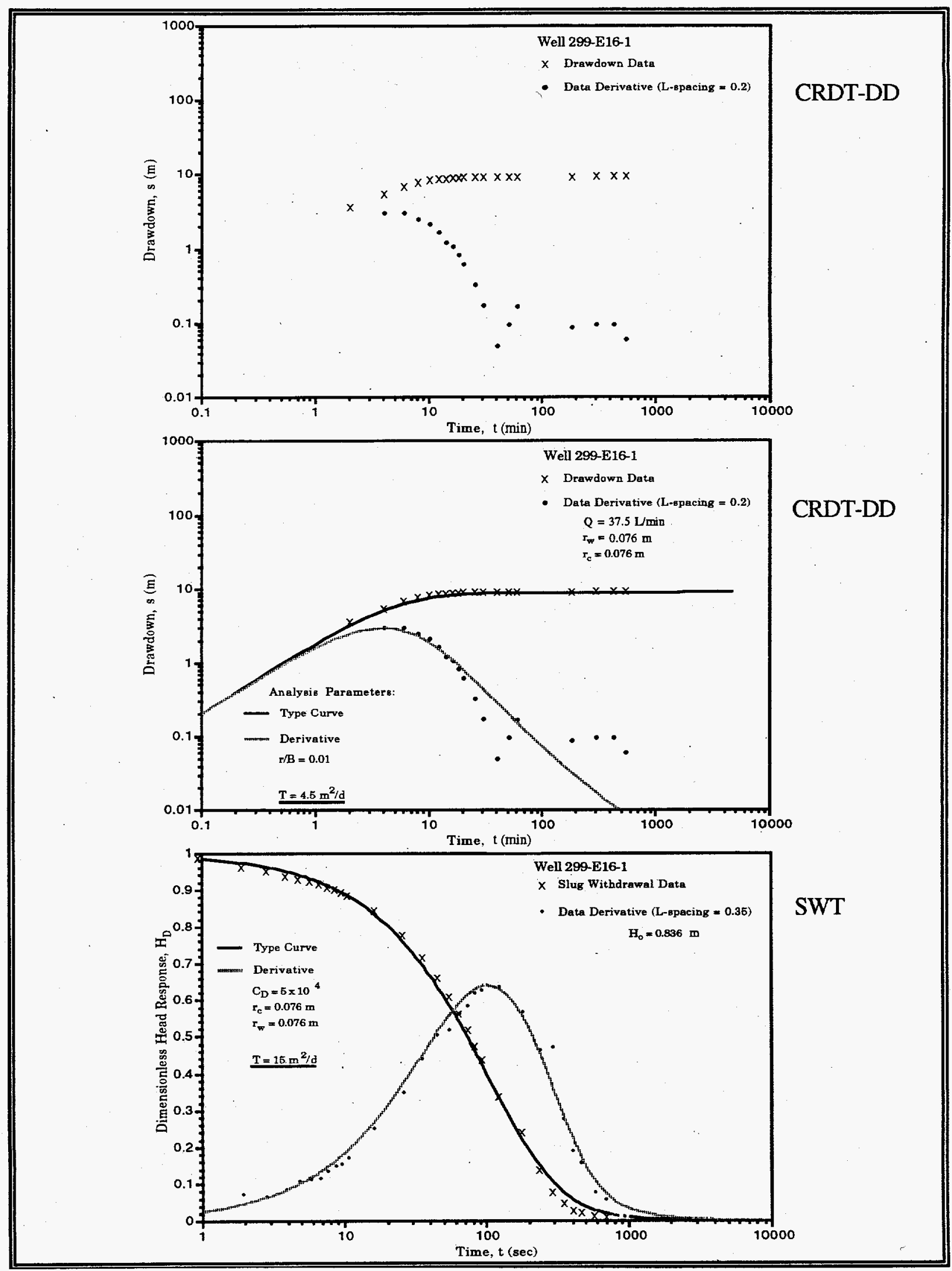

A. 13 


\begin{tabular}{|c|c|c|c|c|}
\hline \multirow{2}{*}{\multicolumn{3}{|c|}{$\begin{array}{ll}\text { Well/Borehole : } 299-E 26-8 \\
\text { Hydrologic Unit : Rattlesnake Ridge Interbed }\end{array}$}} & \multicolumn{2}{|c|}{ Test Interval Depth : $100.6 \mathrm{~m}$ to $121.9 \mathrm{~m}$} \\
\hline & & & \multicolumn{2}{|c|}{ Test Date(s): $\quad 5 / 17-19 / 82 ; 11 / 9 / 82$} \\
\hline \multicolumn{5}{|c|}{ Reference Document(s) : Graham et al. (1984) - RHO-RE-ST-12P; PNL Files } \\
\hline \multicolumn{5}{|c|}{$\begin{array}{l}\text { Test Description: } \\
\text { Hydrologic tests conducted in this interval included a constant-rate discharge drawdown and } \\
\text { recovery test and a slug injection and withdrawal test. The following is a brief description of } \\
\text { testing activities. }\end{array}$} \\
\hline CRDT-DD & \multicolumn{4}{|c|}{$\begin{array}{l}\text { A constant-rate discharge test was conducted for a duration of } 48 \mathrm{hr} \text { at an average } \\
\text { flow rate of } 19.2 \mathrm{~L} / \mathrm{min} \text {. There were difficulties maintaining a constant flow rate, } \\
\text { and test logs indicated a potential for significant barometric pressure variation. } \\
\text { Diagnostic analysis indicates a decrease in flow rate and/or vertical leakage after } \\
1000 \text { min into the test. Straight-line analysis (Cooper and Jacob 1946) of } \\
\text { drawdown data for the time period } 140 \text { to } 1000 \text { min resulted in a transmissivity } \\
\text { estimate of } 3.7 \mathrm{~m} / \mathrm{d} \text {. }\end{array}$} \\
\hline CRDT-RCV & \multicolumn{4}{|c|}{$\begin{array}{l}\text { Recovery response was monitored for a duration of } 760 \text { min following termina- } \\
\text { tion of pumping. Recovery response was affected by drainage from the pump } \\
\text { column; data were not used in the analysis. }\end{array}$} \\
\hline SIT & \multicolumn{4}{|c|}{$\begin{array}{l}\text { A slug injection test was conducted by injecting a slug of known volume, } \\
\text { resulting in a stress level }\left(\mathrm{H}_{\mathrm{o}}\right) \text { of } 0.459 \mathrm{~m} \text {. The slug test exhibited an oversteep- } \\
\text { ened response, resulting from problems during injection of the slug rod. }\end{array}$} \\
\hline SWT & \multicolumn{4}{|c|}{$\begin{array}{l}\text { A slug withdrawal test was conducted by withdrawing a slug of known volume, } \\
\text { resulting in a stress level }\left(\mathrm{H}_{\mathrm{o}} \text { ) of } 0.482 \mathrm{~m} \text {. Combined type-curve and derivative }\right. \\
\text { analysis (Ostrowski and Kloska 1989) resulted in a transmissivity estimate of } \\
7.0 \mathrm{~m}^{2} / \mathrm{d} \text {. The slug test derivative pattern suggests the presence of wellbore } \\
\text { damage (skin effects). }\end{array}$} \\
\hline \multicolumn{5}{|c|}{$\begin{array}{l}\text { Comments: } \\
\text { Reanalysis of the hydrologic test response data discussed above provides comparable results } \\
\text { with previously reported values (i.e., Graham et al. 1984). The reanalysis best estimate is based } \\
\text { on the constant-rate discharge drawdown data. The reanalyses are considered an improvement } \\
\text { over those cited in the reference document; the original analysis made an erroneous type-curve } \\
\text { match for both the slug injection and slug withdrawal tests and reported results for the constant- } \\
\text { rate discharge recovery response; recovery response was affected by drainage from the pump } \\
\text { column }\end{array}$} \\
\hline \multicolumn{5}{|c|}{ Test Interval Specifications: } \\
\hline \multicolumn{5}{|c|}{ Effective Thickness : $16.8 \mathrm{~m}$} \\
\hline \multicolumn{2}{|c|}{ Transmissivity } & $\begin{array}{l}\text { Range : } 3-22 \mathrm{~m} / \mathrm{d} \\
\text { (Graham et al. } 1984 \text { ) }\end{array}$ & & $\begin{array}{l}\text { ge : } \quad 3.7-7.0 \mathrm{~m}^{2} / \mathrm{d} \\
\text { t Estimate : } 3.7 \mathrm{~m}^{2} / \mathrm{d}\end{array}$ \\
\hline
\end{tabular}




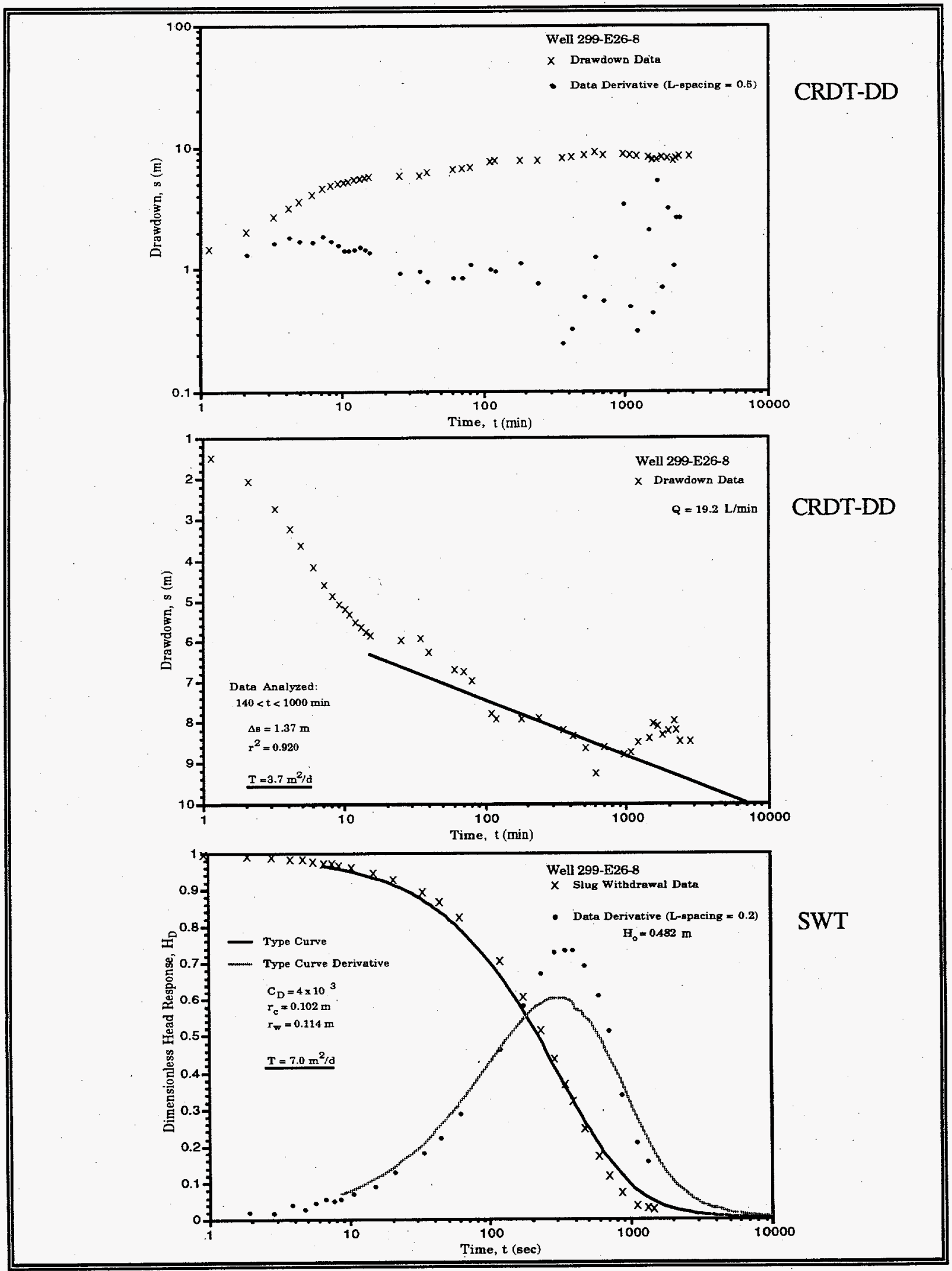

A. 15 


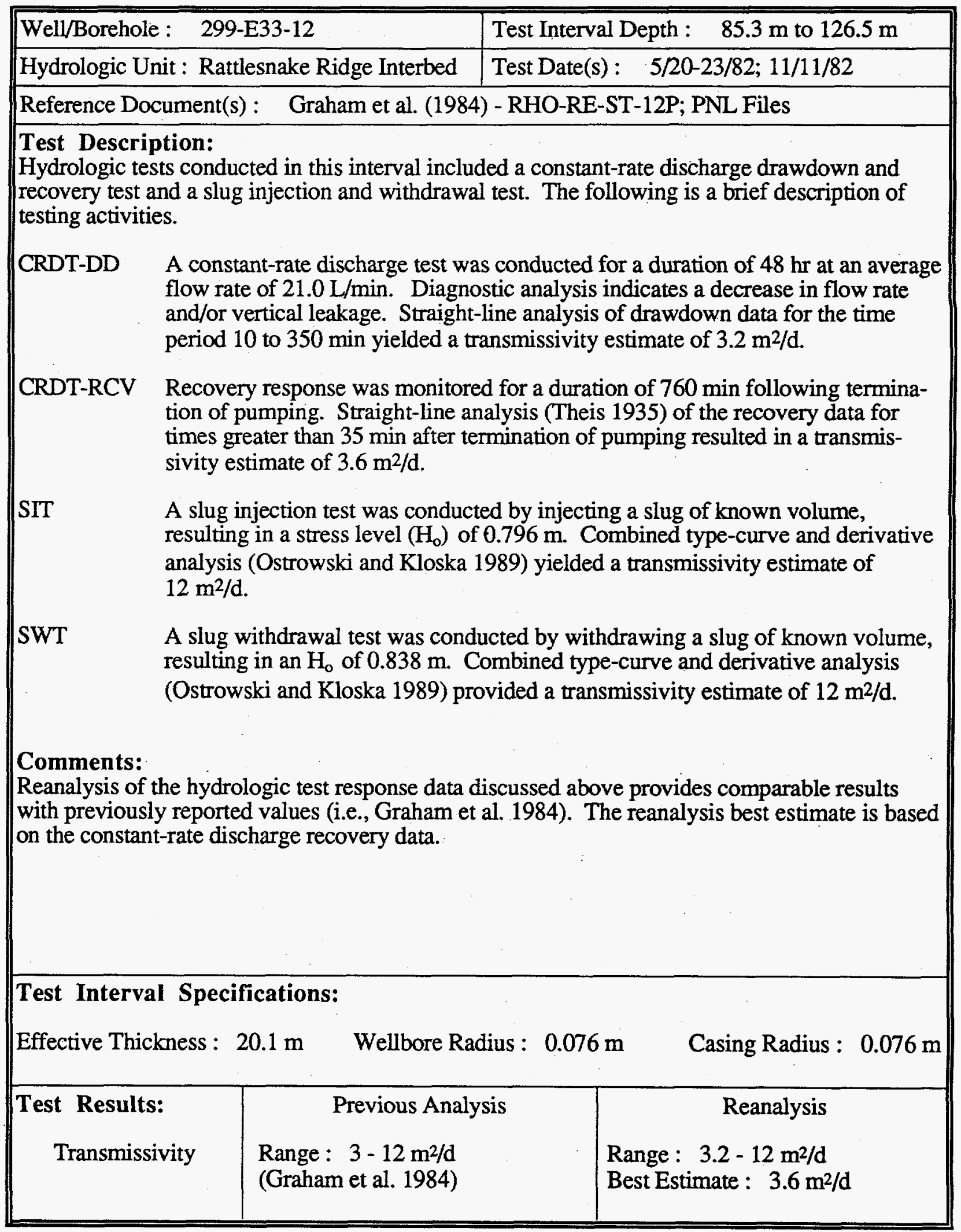




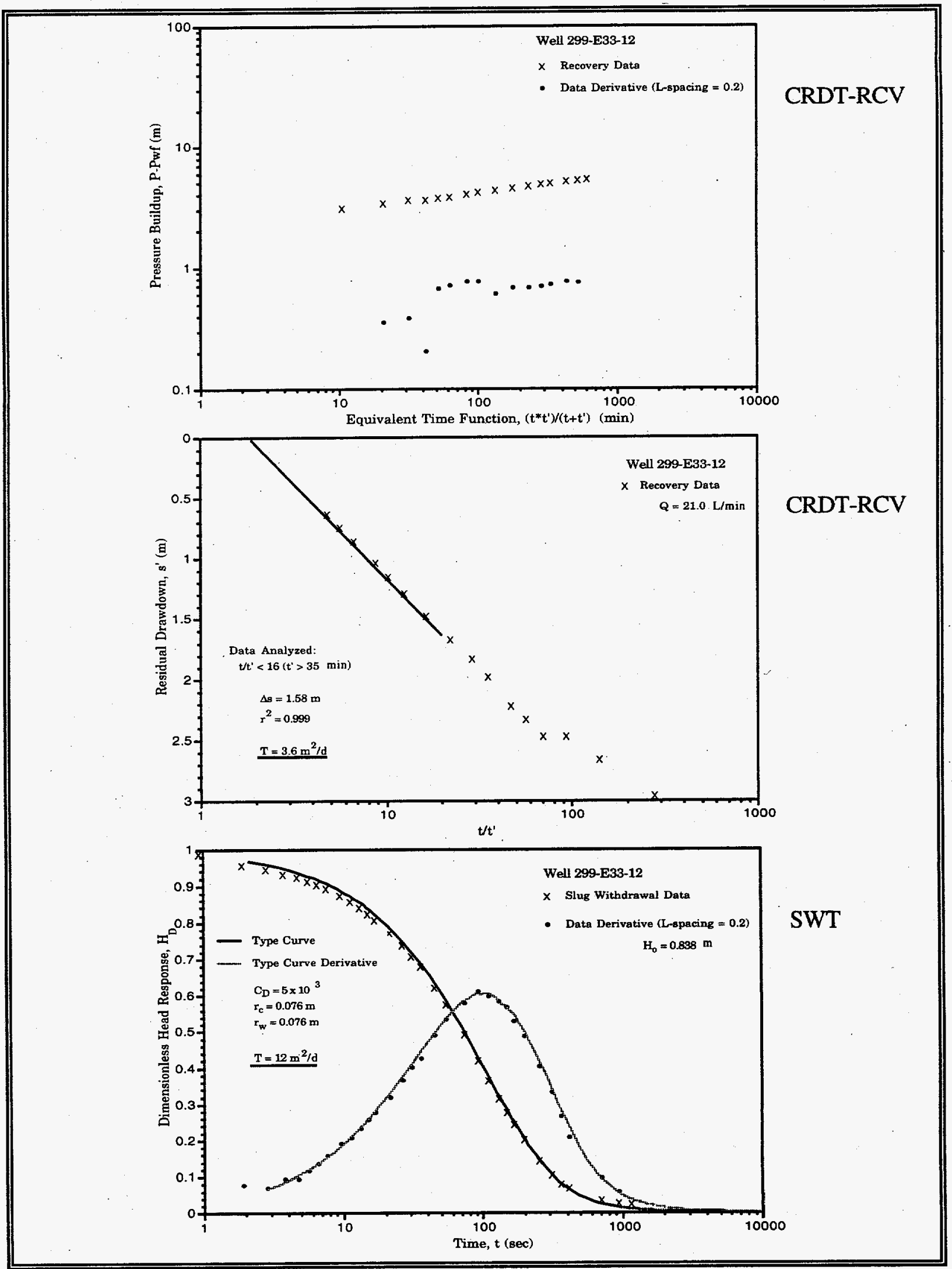

A. 17 


\begin{tabular}{|l|l|}
\hline $\begin{array}{l}\text { Well/Borehole : 399-5-2 } \\
\text { Hydrologic Unit : Composite Upper Saddle } \\
\text { Mountains Basalt }\end{array}$ & Test Date(s) : 2/16-17/70;2/19/70 \\
\hline Reference Document(s) : PNL Files & \\
\hline
\end{tabular}

Test Description:

Hydrologic tests conducted in this interval included two constant-rate discharge drawdown and recovery tests. The following is a brief description of the testing activities.

CRDT-DD1 A constant-rate discharge test was conducted for a duration of $1417 \mathrm{~min}$ at an average flow rate of $11.4 \mathrm{~L} / \mathrm{min}$. Diagnostic analysis indicates leaky confined aquifer conditions as well as borehole development during the test. No quantitative analysis was performed.

CRDT-RCV1 Recovery following termination of the constant-rate test was monitored for a duration of $238 \mathrm{~min}$. Diagnostic analysis of the recovery data indicated leaky confined aquifer conditions. Reanalysis results, using a leaky confined aquifer type-curve model (Hantush and Jacob $1955 \mathrm{r} / \mathrm{B}$ solution method); indicate a transmissivity of $1.6 \mathrm{~m} 2 / \mathrm{d}$.

CRDT-DD2 A constant-rate discharge test was conducted for a duration of $126 \mathrm{~min}$ at an average flow rate of $56.8 \mathrm{~L} / \mathrm{min}$. Diagnostic analysis indicates either leaky confined aquifer conditions and possible well development during the test.

CRDT-RCV2 Recovery following termination of the constant-rate test was monitored for a duration of $217 \mathrm{~min}$. Diagnostic derivative analysis of the recovery data indicated leaky confined aquifer conditions. Reanalysis results, using a leaky confined aquifer type-curve model (Hantush and Jacob 1955 r/B solution method), indicate a transmissivity of $2.2 \mathrm{~m} / \mathrm{d}$.

\section{Comments:}

Reanalysis of the hydrologic test response data discussed above provides slightly higher estimates for transmissivity than previously reported values in PNL files. Although similar in value, the reanalysis results are considered to be an improvement over the previously reported values because of the original analysis dependence on a nonleaky confined aquifer model for test response description. The reanalysis best estimate represents the average of test results obtained from the constant-rate discharge recovery analyses. Because of the composite test interval/well completion conditions, property estimates obtained from the test analyses cannot be assigned to a specific hydrogeologic unit within the upper basalt confined aquifer.

Test Interval Specifications:

Effective Thickness : $69.8 \mathrm{~m} \quad$ Wellbore Radius : $0.102 \mathrm{~m} \quad$ Casing Radius : $0.102 \mathrm{~m}$

\begin{tabular}{|c|l|l|}
\hline Test Results: & \multicolumn{1}{|c|}{ Previous Analysis } & \multicolumn{1}{c|}{ Reanalysis } \\
Transmissivity & $\begin{array}{l}\text { Range : } 0.55-0.64 \mathrm{~m}^{2} / \mathrm{d} \\
\text { (PNL Files) }\end{array}$ & $\begin{array}{l}\text { Range : } 1.6-2.2 \mathrm{~m}^{2} / \mathrm{d} \\
\text { Best Estimate }: 1.9 \mathrm{~m} / \mathrm{d}\end{array}$ \\
\hline
\end{tabular}




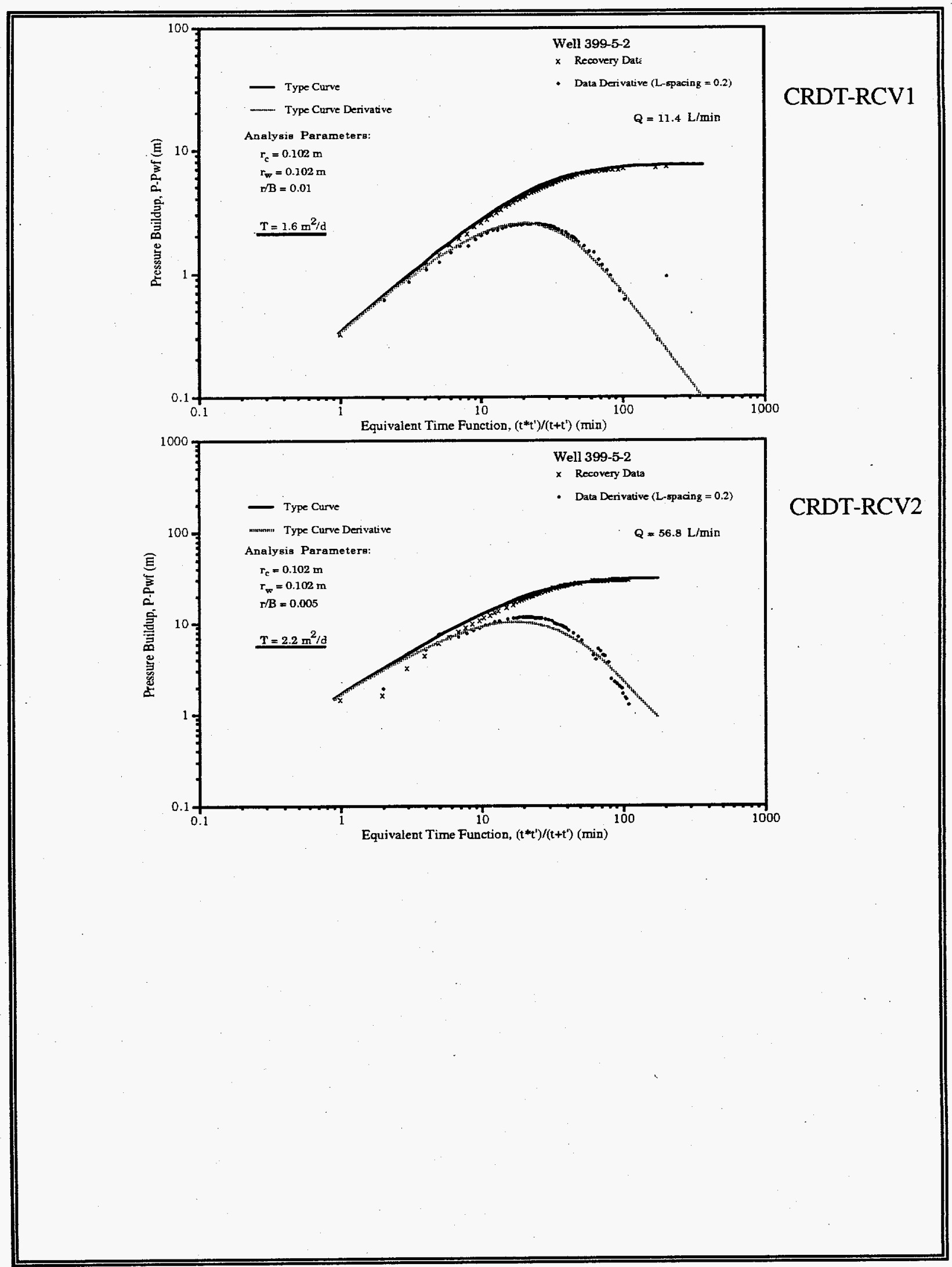

A. 19 


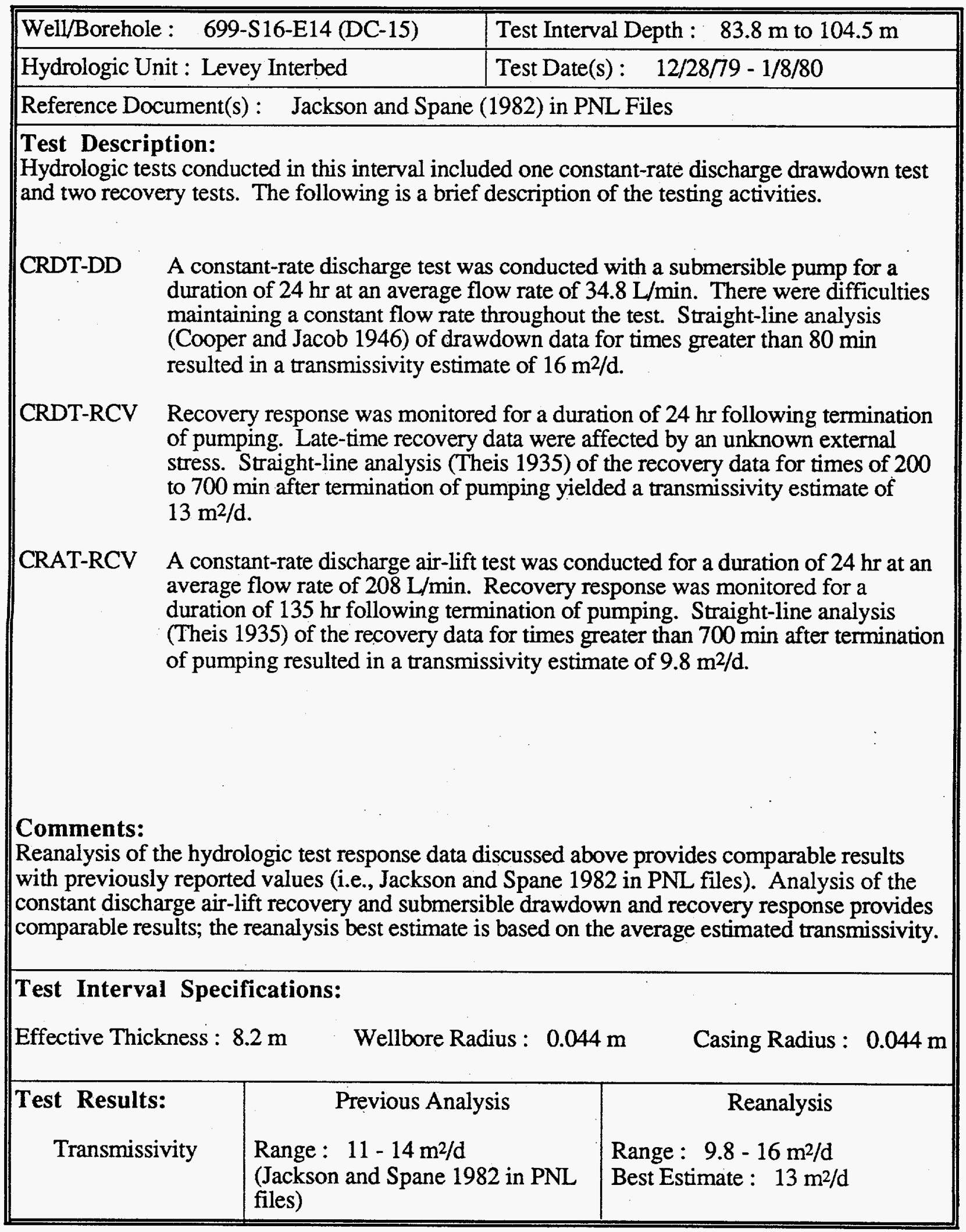




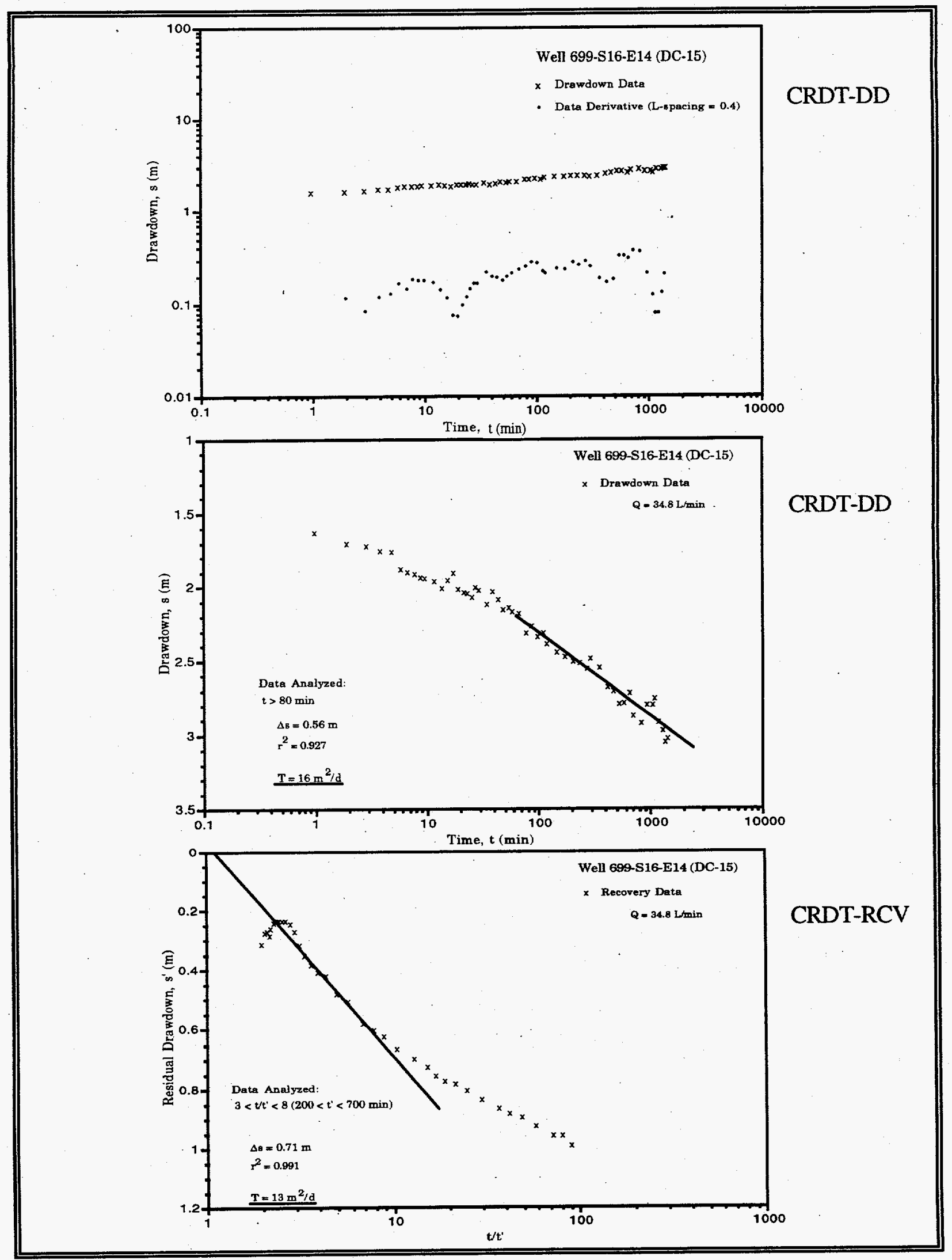




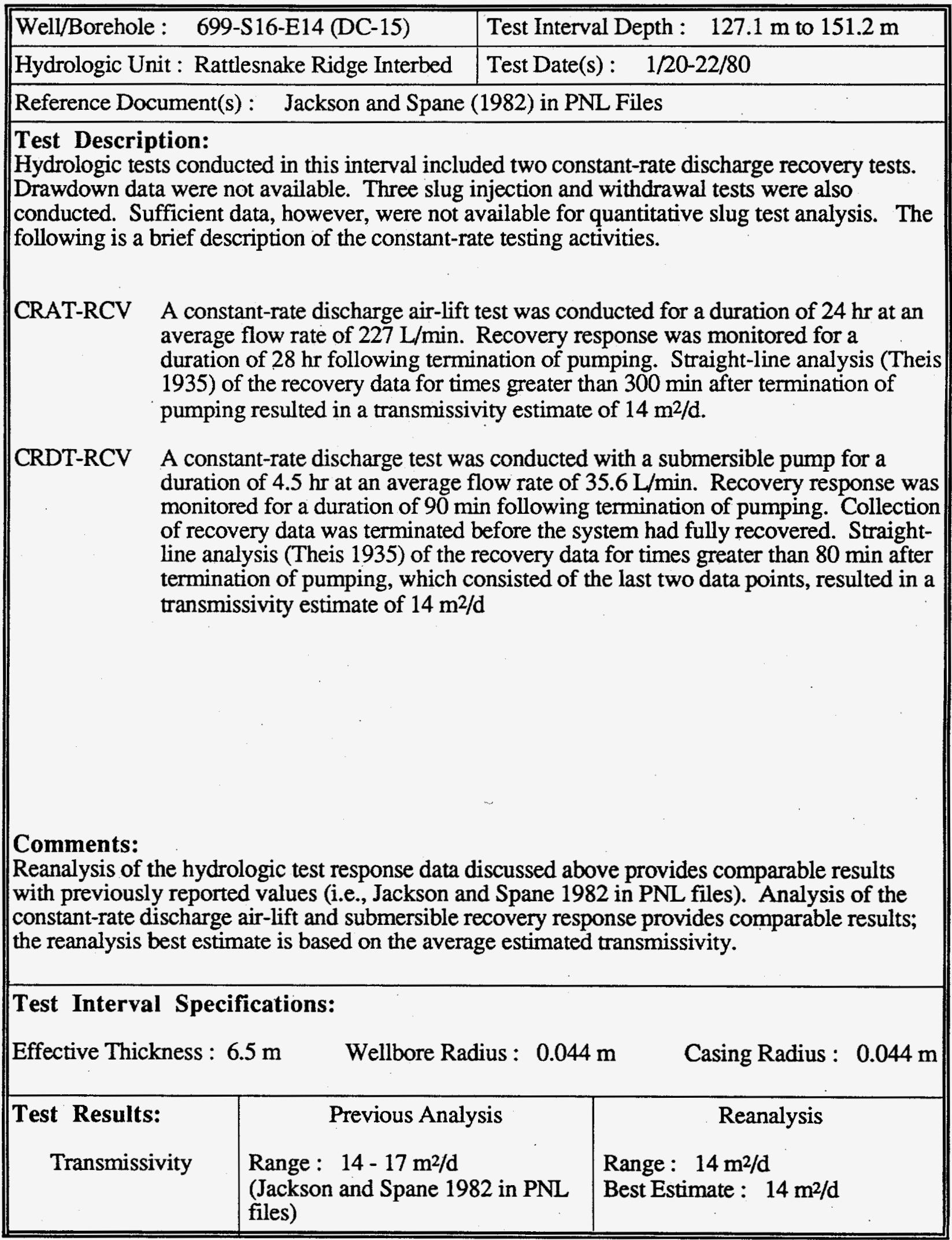




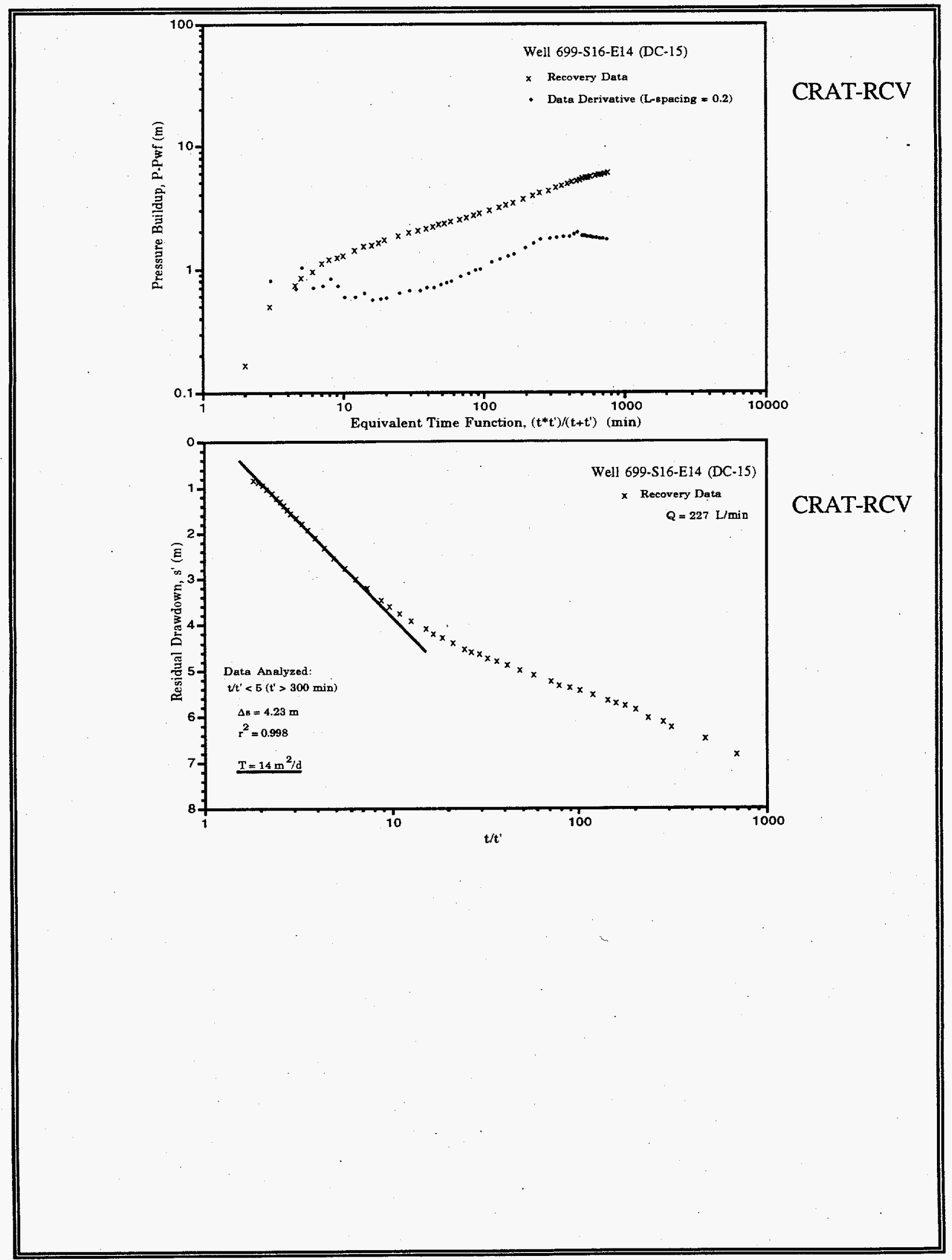




\begin{tabular}{|c|c|c|c|c|}
\hline \multirow{2}{*}{\multicolumn{3}{|c|}{$\begin{array}{l}\text { Well/Borehole : } 699-13-1 \mathrm{C} \\
\text { Hydrologic Unit : Composite Upper Saddle } \\
\text { Mountains Basalt }\end{array}$}} & \multicolumn{2}{|c|}{ Test Interval Depth : $154.2 \mathrm{~m}$ to $211.8 \mathrm{~m}$} \\
\hline & & & \multicolumn{2}{|c|}{ Test Date(s) : $7 / 22-23 / 78 ; 11 / 18-19 / 78$} \\
\hline \multicolumn{5}{|c|}{ Reference Document(s) : Gephart et al. (1979) - RHO-BWI-ST-5; PNL Files } \\
\hline \multicolumn{5}{|c|}{$\begin{array}{l}\text { Test Description: } \\
\text { Hydrologic tests conducted in this interval included two constant-rate discharge drawdown and } \\
\text { recovery tests. The following is a brief description of the testing activities. }\end{array}$} \\
\hline CRDT-DD1 & \multicolumn{4}{|c|}{$\begin{array}{l}\text { A constant-rate discharge test was conducted for a duration of } 1740 \mathrm{~min} \text { at an } \\
\text { average flow rate of } 1703 \mathrm{~L} / \mathrm{min} \text {. Diagnostic analysis indicates leaky confined } \\
\text { aquifer conditions and possible turbulent well-loss effects during the test. } \\
\text { Reanalysis results, using a leaky confined aquifer type-curve model (Hantush } \\
\text { and Jacob } 1955 \mathrm{r} / \mathrm{B} \text { solution method), indicate a transmissivity of } 7.0 \mathrm{~m} / \mathrm{d} \text {. }\end{array}$} \\
\hline CRDT-RCV1 & \multicolumn{4}{|c|}{$\begin{array}{l}\text { Recovery following termination of the constant-rate test was monitored routinely } \\
\text { for a duration of } 230 \mathrm{~min} \text {. Diagnostic analysis of the recovery data indicated } \\
\text { leaky confined aquifer conditions. }\end{array}$} \\
\hline CRDT-DD2 & \multicolumn{4}{|c|}{$\begin{array}{l}\text { A second constant-rate discharge test was conducted after completing the well } \\
\text { with a well screen and sand/gravel pack. The test was conducted for a duration } \\
\text { of } 1511 \mathrm{~min} \text { at an average flow rate of } 1041 \mathrm{~L} / \mathrm{min} \text {. Diagnostic derivative } \\
\text { analysis comoborate conditions exhibited for the earlier test. }\end{array}$} \\
\hline CRDT-RCV2 & \multicolumn{4}{|c|}{$\begin{array}{l}\text { Recovery following termination of the constant-rate test was monitored routinely } \\
\text { for the first } 15 \mathrm{~min} \text { and then measured three times for the next } 105 \mathrm{~min} \text {. The } \\
\text { recovery data were combined with the drawdown data to provide a more } \\
\text { complete response for the constant-rate test. Reanalysis results, using a leaky } \\
\text { confined aquifer type-curve model (Hantush and Jacob } 1955 \mathrm{r} / \mathrm{B} \text { solution } \\
\text { method), indicate a transmissivity of } 12 \mathrm{~m} 2 / \mathrm{d} \text {. }\end{array}$} \\
\hline \multicolumn{5}{|c|}{$\begin{array}{l}\text { Comments: } \\
\text { Reanalysis of the hydrologic test response data discussed above provides significantly lower } \\
\text { estimates for transmissivity than previously reported values in PNL files. There is a high level } \\
\text { of uncertainty in the reanalysis results, however, because head-loss effects are not accounted for. } \\
\text { Conversely, the previous analyses were based on a nonleaky confined aquifer model, which } \\
\text { would significantly over estimate transmissivity when misapplied to leaky confined test forma- } \\
\text { tion conditions. }\end{array}$} \\
\hline \multicolumn{5}{|c|}{ Test Interval Specifications: } \\
\hline \multicolumn{3}{|c|}{ Interval Length : $57.6 \mathrm{~m}$} & is : $0.152 \mathrm{~m}$ & Casing Radius : $0.152 \mathrm{~m}$ \\
\hline \multicolumn{2}{|c|}{$\begin{array}{l}\text { Test Results: } \\
\text { Transmissivity }\end{array}$} & $\begin{array}{l}\text { Range : } 409 \\
\text { (Gephart et al. }\end{array}$ & & $\begin{array}{l}\text { Range : } 7.0-12 \mathrm{~m}^{2} / \mathrm{d} \\
\text { Best Estimate : } 9.5 \mathrm{~m}^{2} / \mathrm{d}\end{array}$ \\
\hline
\end{tabular}




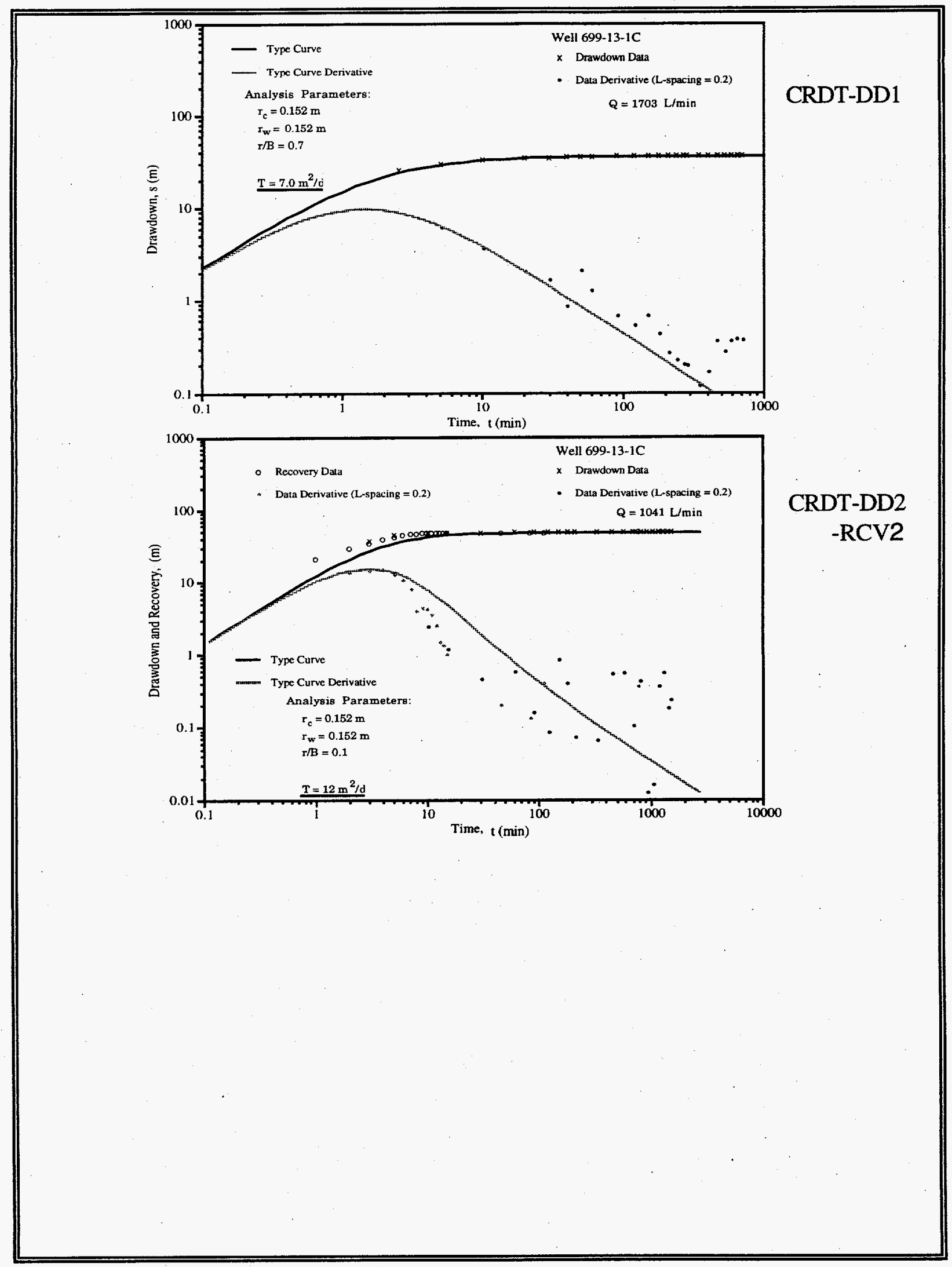




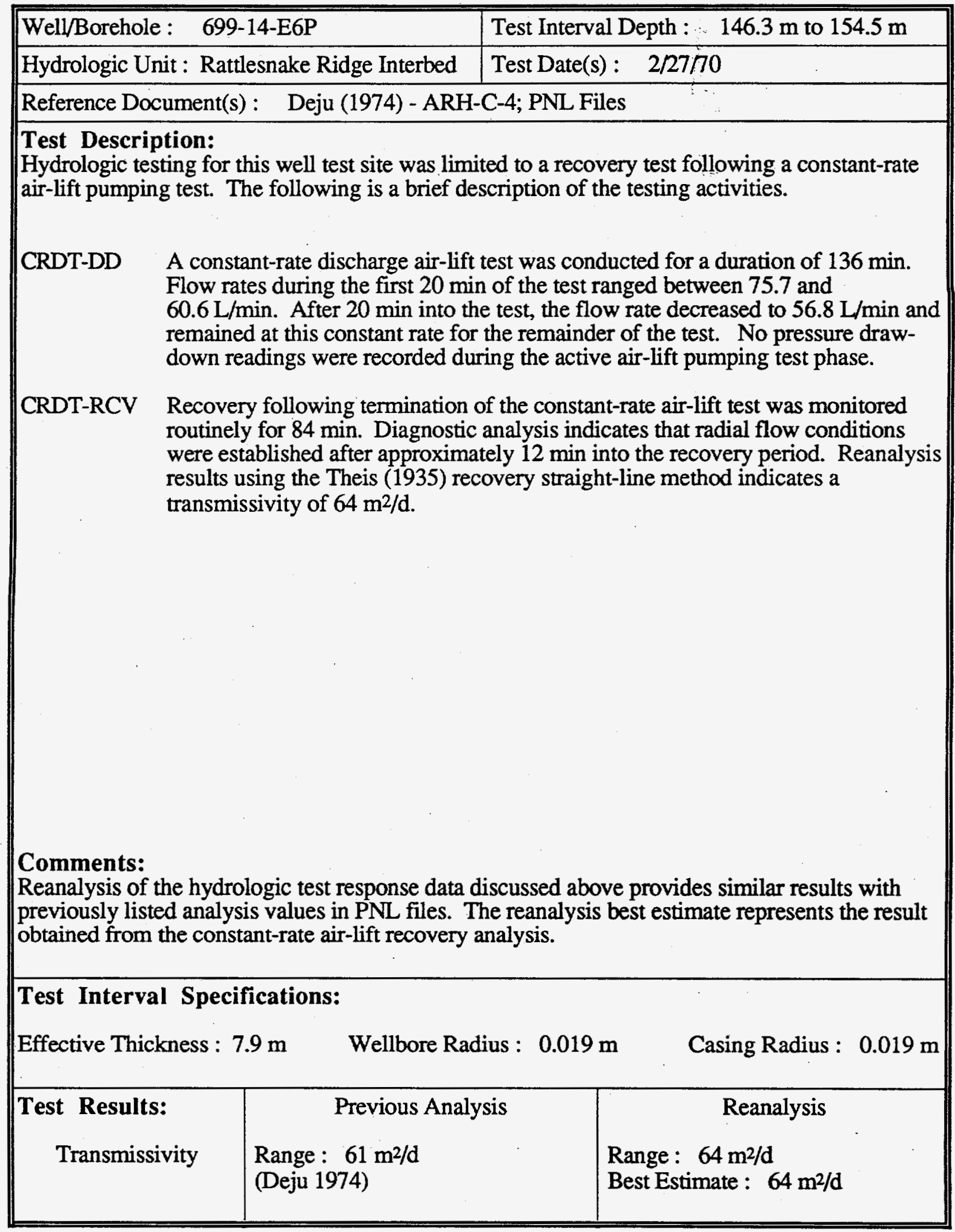




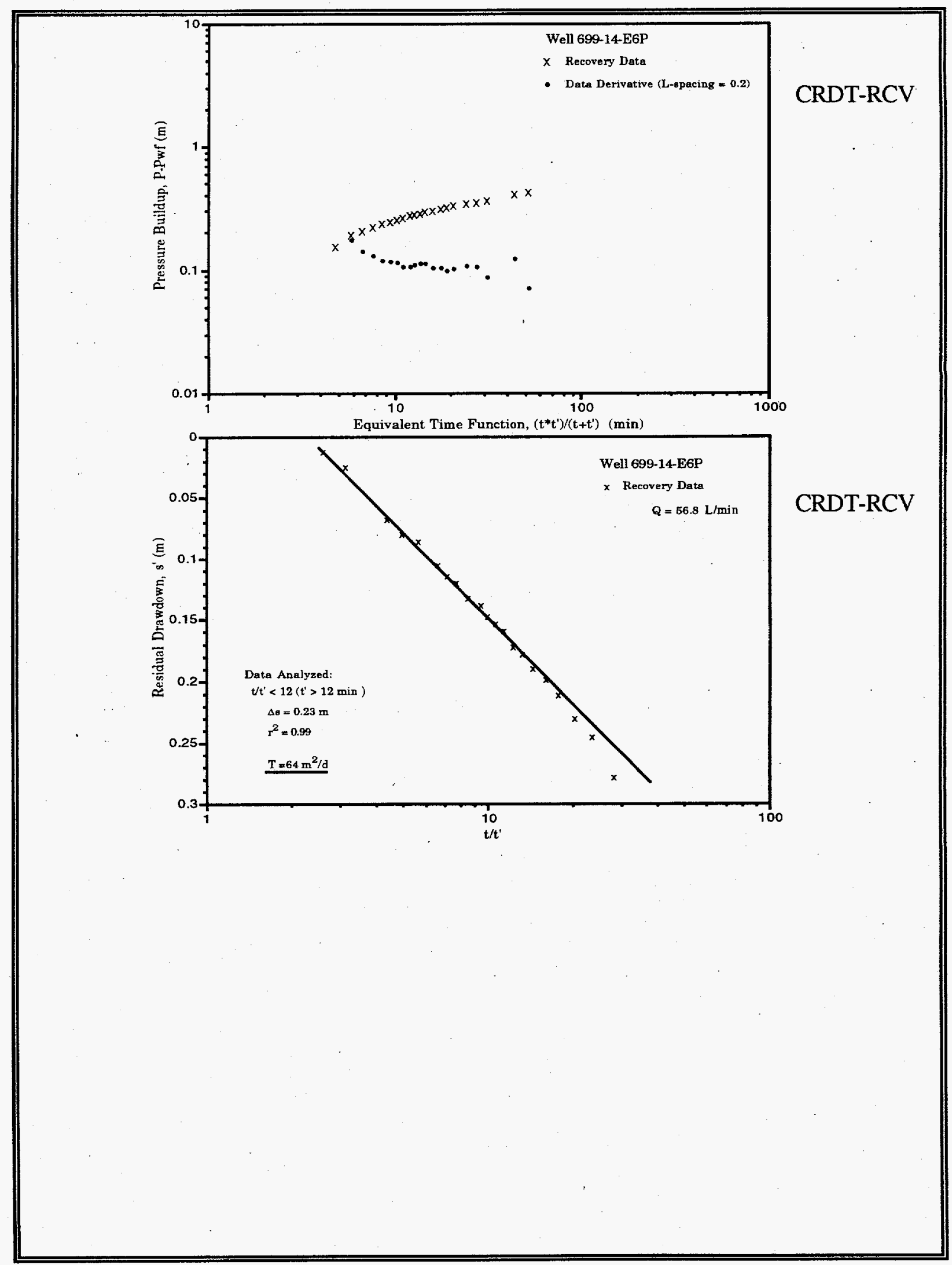




\begin{tabular}{|c|c|c|c|c|}
\hline \multirow{2}{*}{\multicolumn{3}{|c|}{\begin{tabular}{|ll} 
Well/Borehole : & $699-24-1 \mathrm{P}$ \\
Hydrologic Unit : & Ringold Formation and \\
Elephant Mt. Member
\end{tabular}}} & \multicolumn{2}{|c|}{ Test Interval Depth : $132.6 \mathrm{~m}$ to $163.7 \mathrm{~m}$} \\
\hline & & & \multicolumn{2}{|c|}{ Test Date(s): $3 / 17-19 / 70$} \\
\hline \multicolumn{5}{|c|}{ Reference Document(s): Deju (1974) - ARH-C-4; PNL Files } \\
\hline \multicolumn{5}{|c|}{$\begin{array}{l}\text { Test Description: } \\
\text { Hydrologic testing for this well test site was limited to a recovery test following a constant-rate } \\
\text { air-lift pumping test. The following is a brief description of the testing activities. }\end{array}$} \\
\hline CRDT-DD & \multicolumn{4}{|c|}{$\begin{array}{l}\text { A constant-rate discharge air-lift test was conducted for a duration of } 313 \mathrm{~min} \text {. } \\
\text { Flow rates during the first } 30 \mathrm{~min} \text { of the test were reported as } 26.5 \mathrm{~L} / \mathrm{min} \text {. In an } \\
\text { attempt to increase discharge, the air-line conductor pipe was lowered after } \\
30 \text { min and flow rates increased and remained constant at } 30.3 \mathrm{~L} / \mathrm{min} \text { for the } \\
\text { remainder of the test. No pressure drawdown readings were recorded during the } \\
\text { active air-lift pumping test phase. }\end{array}$} \\
\hline CRDT-RCV & \multicolumn{4}{|c|}{$\begin{array}{l}\text { Recovery following termination of the constant-rate air-lift test was monitored } \\
\text { routinely for } 100 \text { min. One long-term recovery water-level measurement was } \\
\text { recorded at a recovery test time of } 2628 \text { min following termination of air-lift } \\
\text { pumping. Diagnostic derivative analysis indicates that radial flow conditions } \\
\text { were established after approximately } 30 \text { min into the recovery period. Reanalysis } \\
\text { results using the Theis (1935) recovery method and Agarwal (1980) recovery } \\
\text { straight-line methods both indicate a transmissivity of } 8.1 \mathrm{~m} / \mathrm{d} \text {. }\end{array}$} \\
\hline \multicolumn{5}{|c|}{$\begin{array}{l}\text { Comments: } \\
\text { Reanalysis of the hydrologic test response data discussed above provides identical results with } \\
\text { previously reported values in Deju (1974). The reanalysis best estimate represents the result } \\
\text { obtained from the constant-rate air-lift recovery analysis. There is uncertainty as to what the } \\
\text { hydraulic property estimate represents, however, because the test interval is completed } \\
\text { compositively in the lower Ringold Formation and Elephant Mountain Member. Because of this } \\
\text { uncertainty, test results will not be included in the property summary. }\end{array}$} \\
\hline \multicolumn{5}{|c|}{ Test Interval Specifications: } \\
\hline \multicolumn{3}{|c|}{ Effective Thickness : $31.1 \mathrm{~m}$} & \multicolumn{2}{|c|}{ Wellbore Radius : $0.019 \mathrm{~m} \quad$ Casing Radius : $0.019 \mathrm{~m}$} \\
\hline \multicolumn{2}{|c|}{ Transmissivity } & \multicolumn{2}{|c|}{$\begin{array}{l}\text { Range : } 8.1 \mathrm{~m}^{2} / \mathrm{d} \\
\text { (Deju 1974) }\end{array}$} & $\begin{array}{c}\text { Reanalysis } \\
: 8.1 \mathrm{~m}^{2 / \mathrm{d}} \\
\text { stimate }: 8.1 \mathrm{~m}^{2} / \mathrm{d}\end{array}$ \\
\hline
\end{tabular}




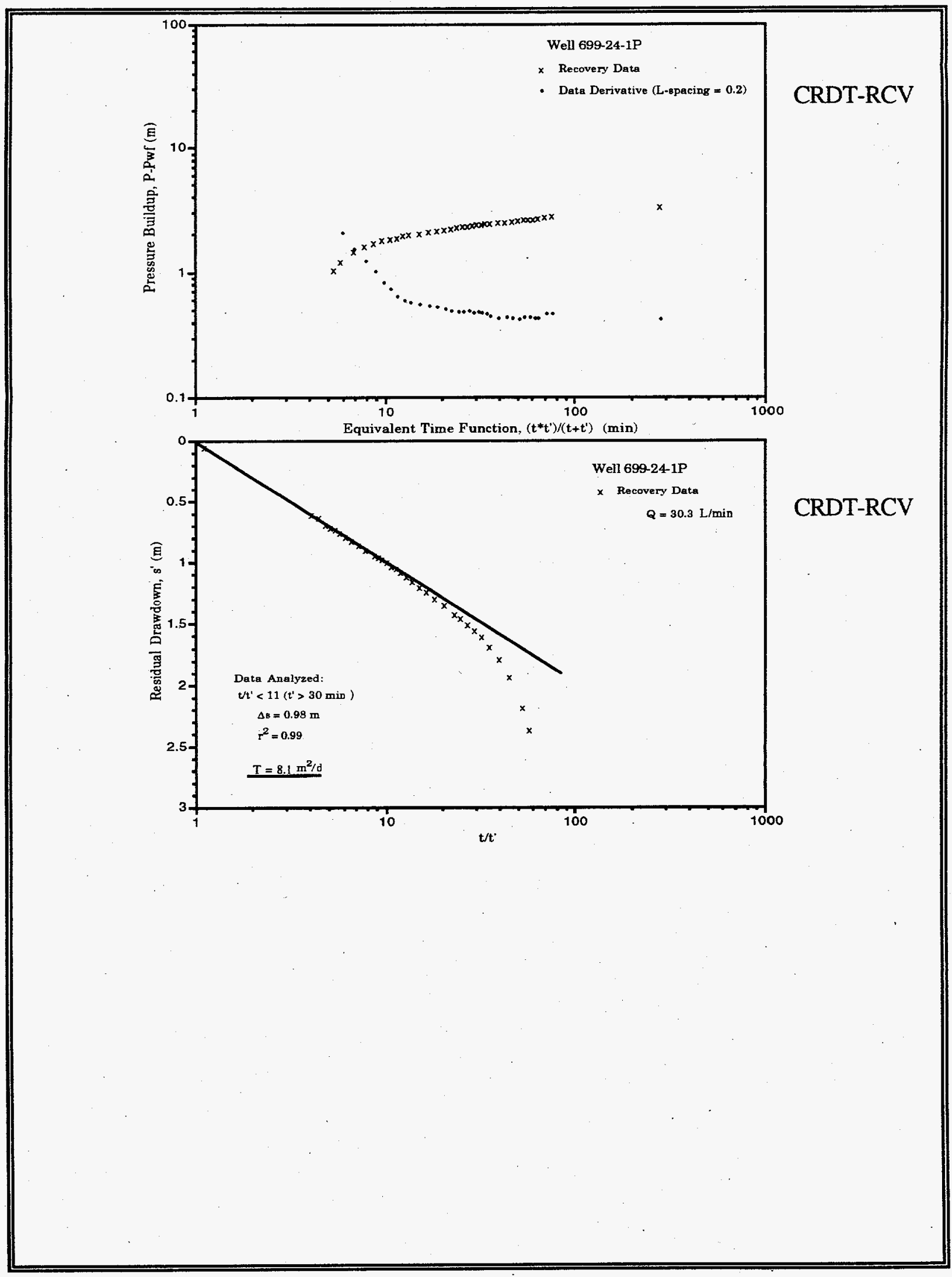




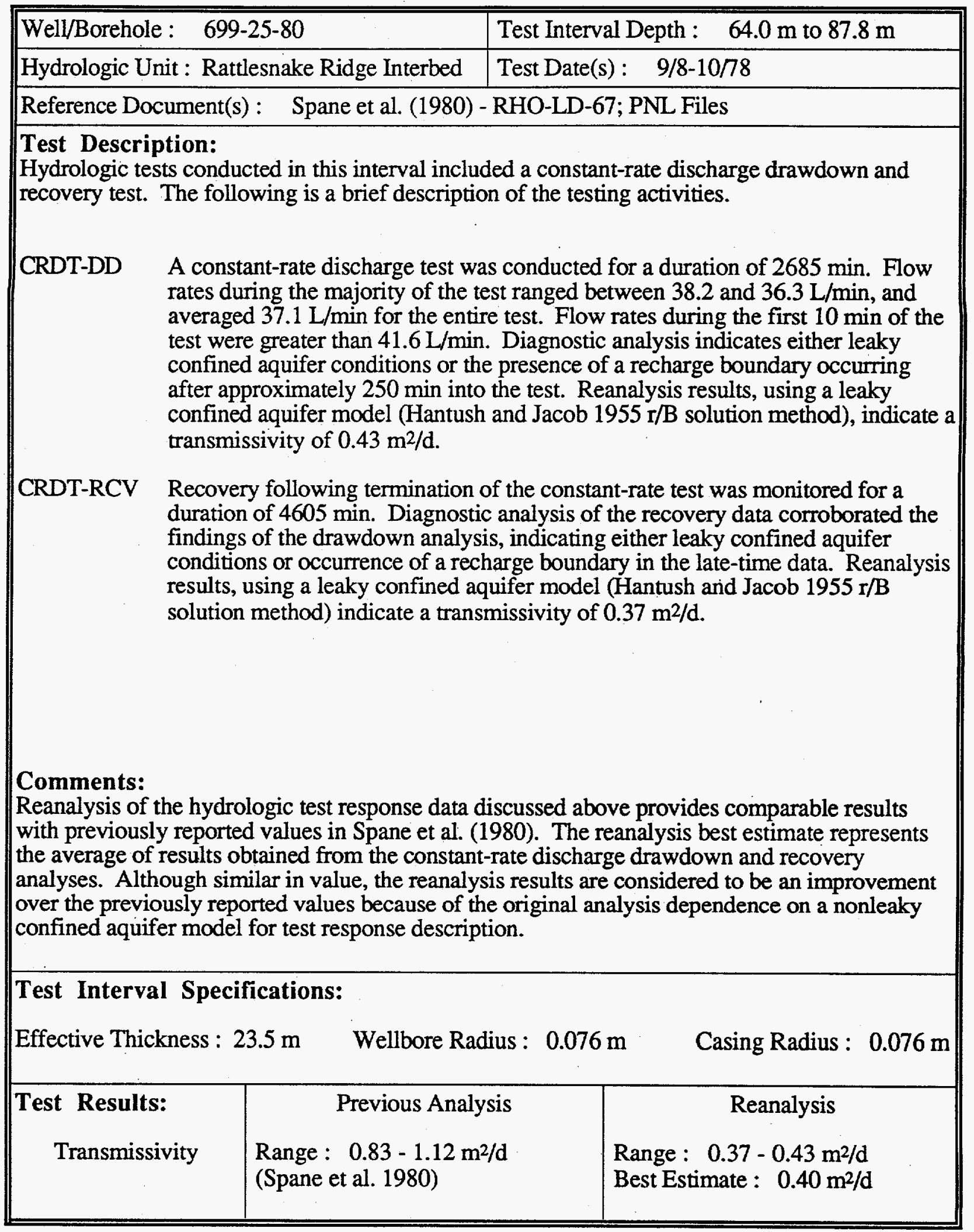




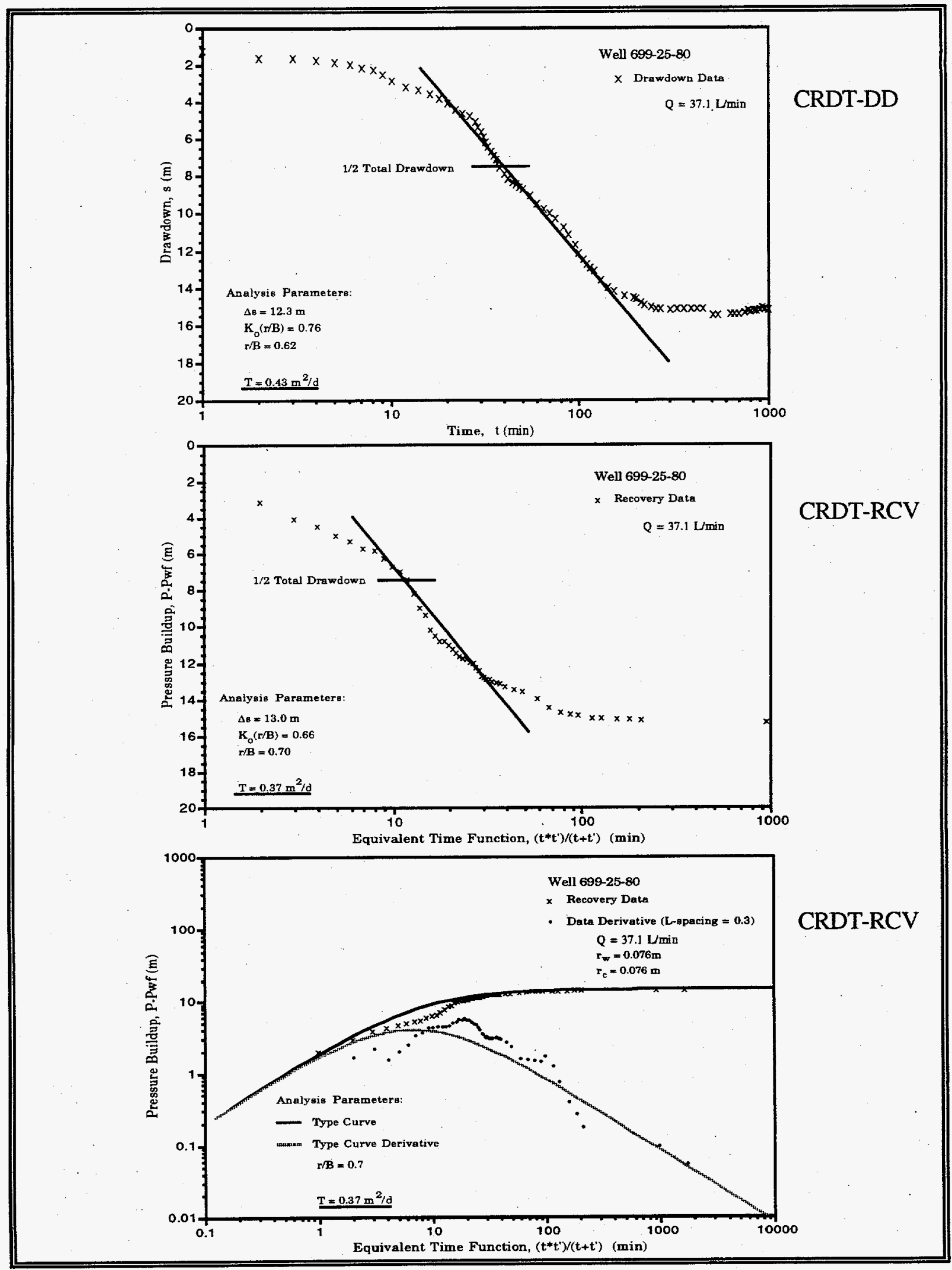

A. 31 


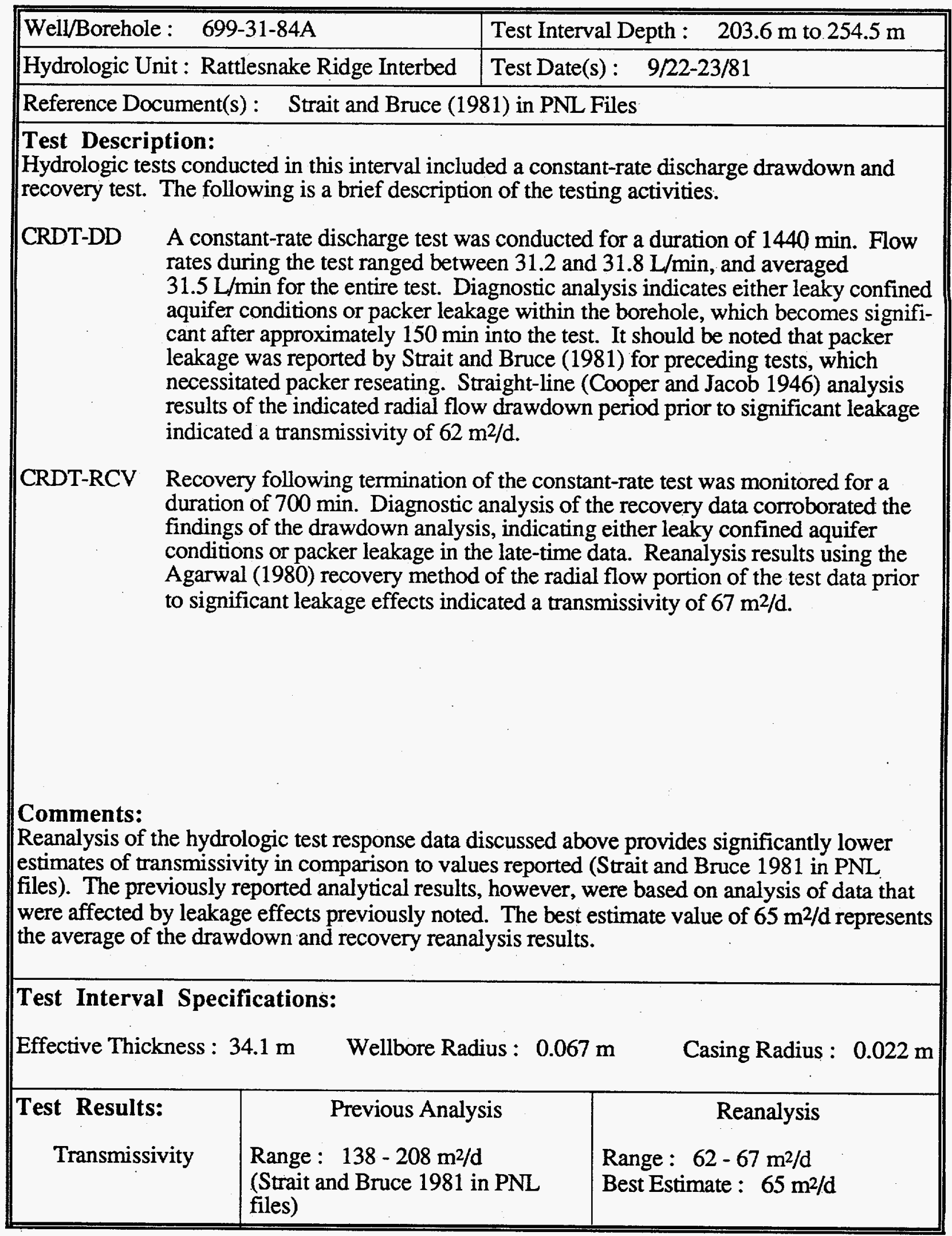




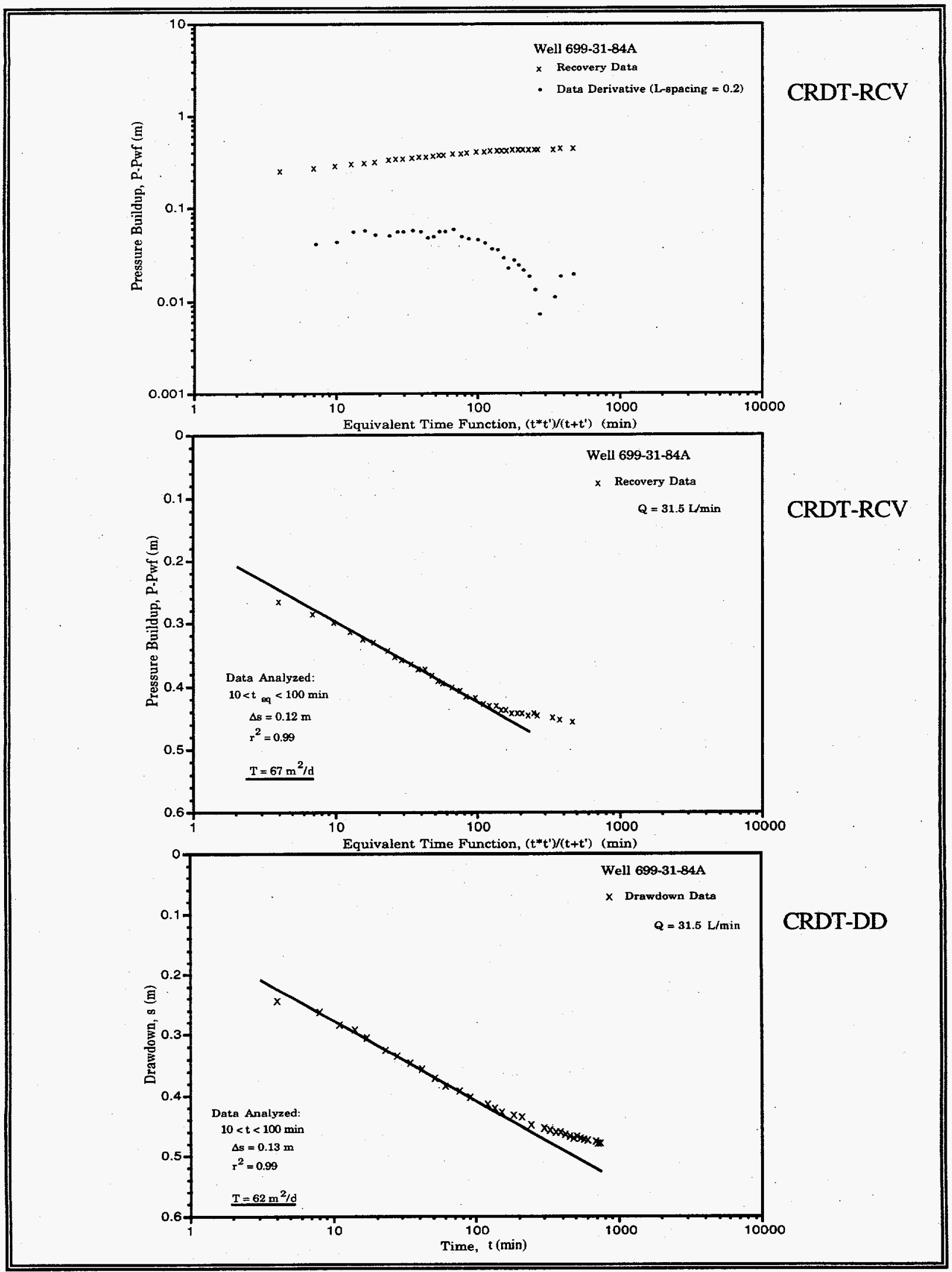

A. 33 


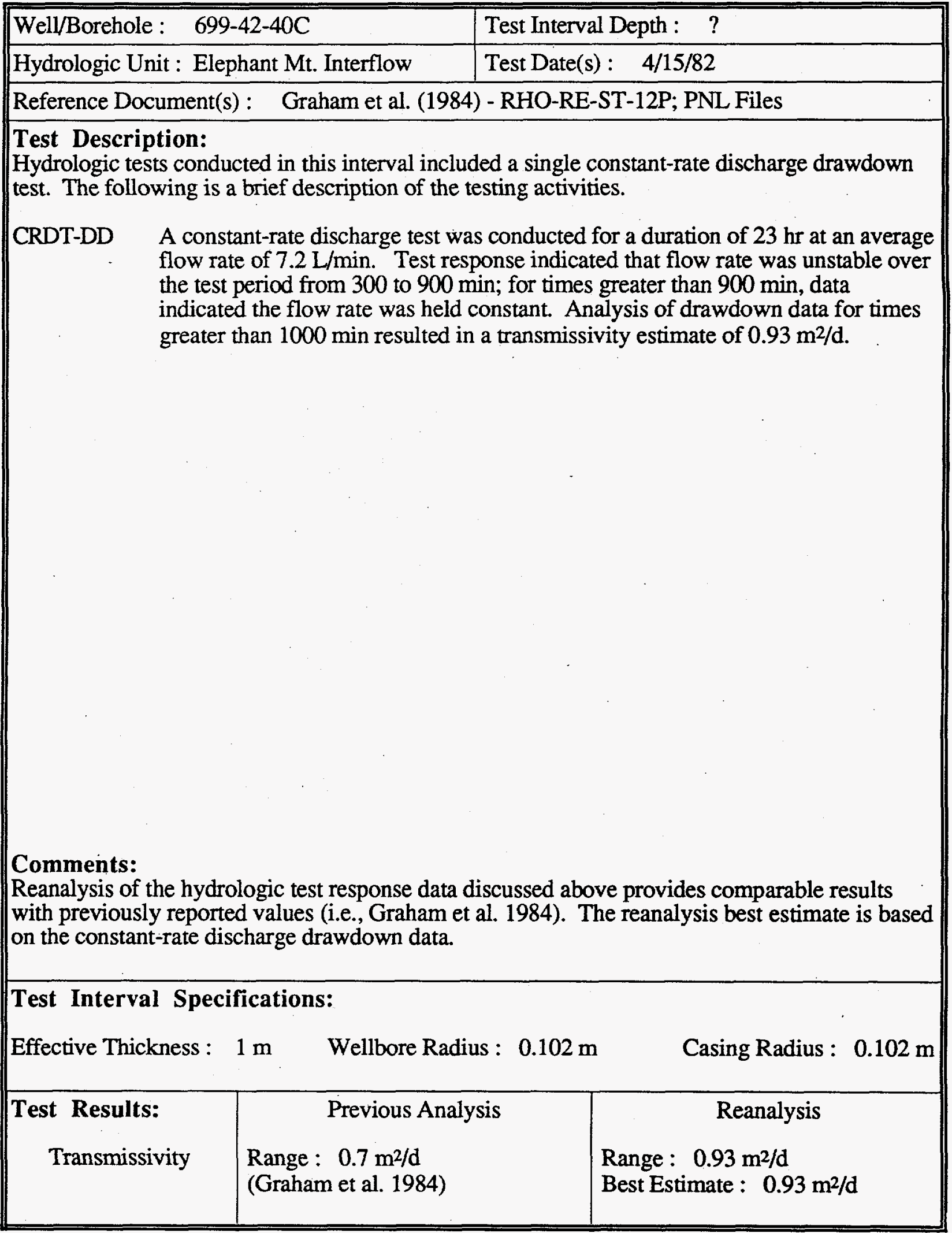




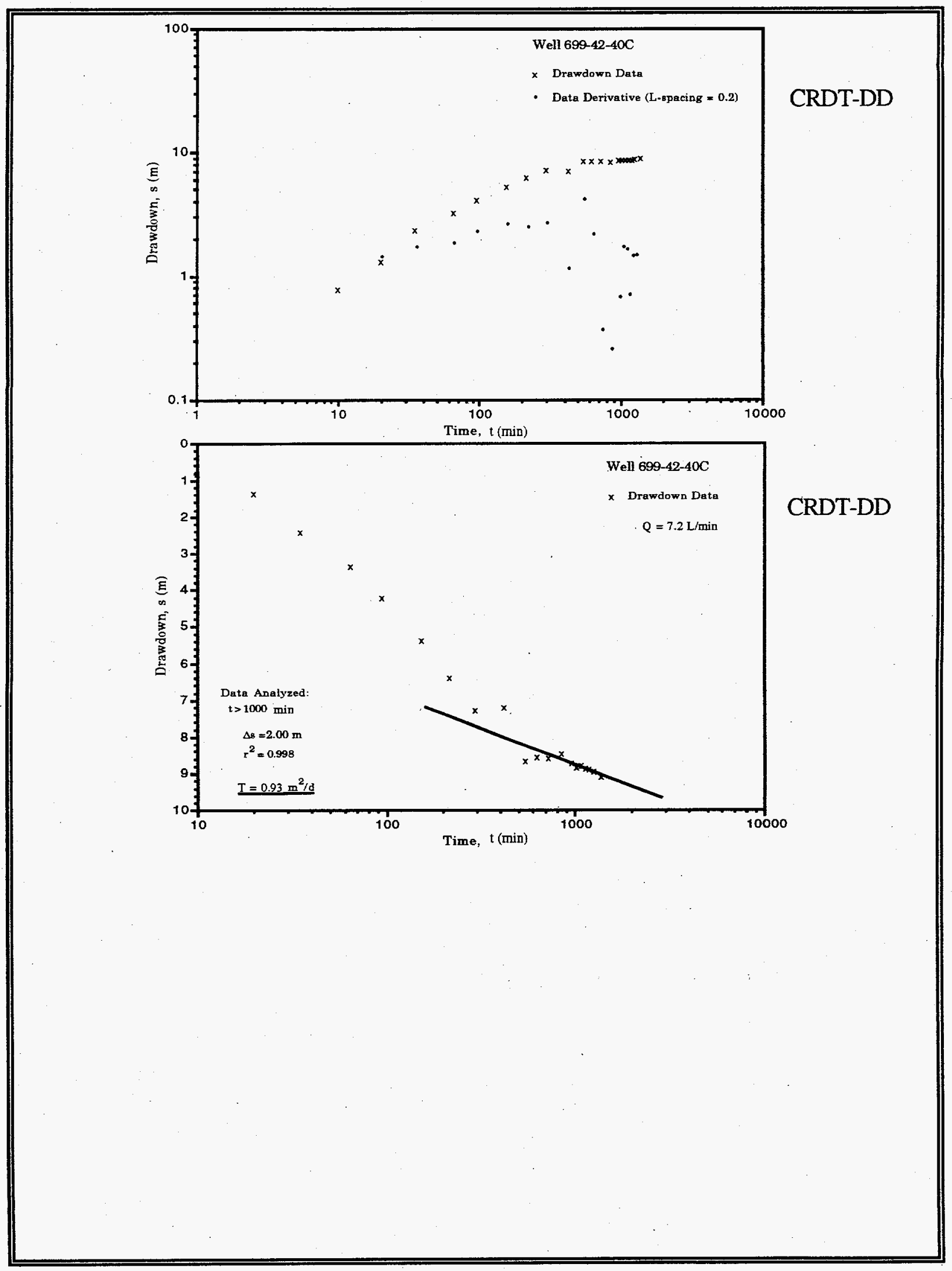




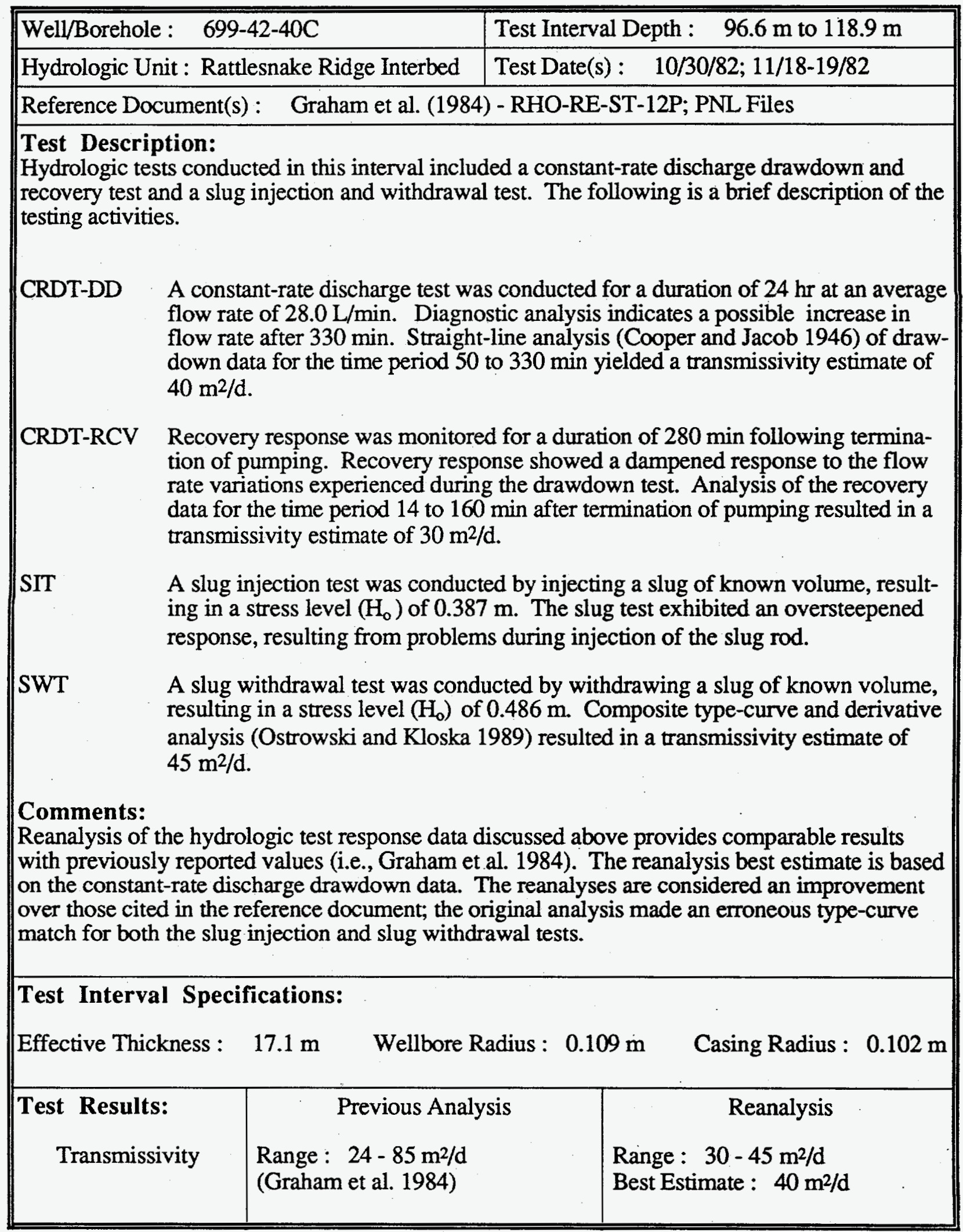




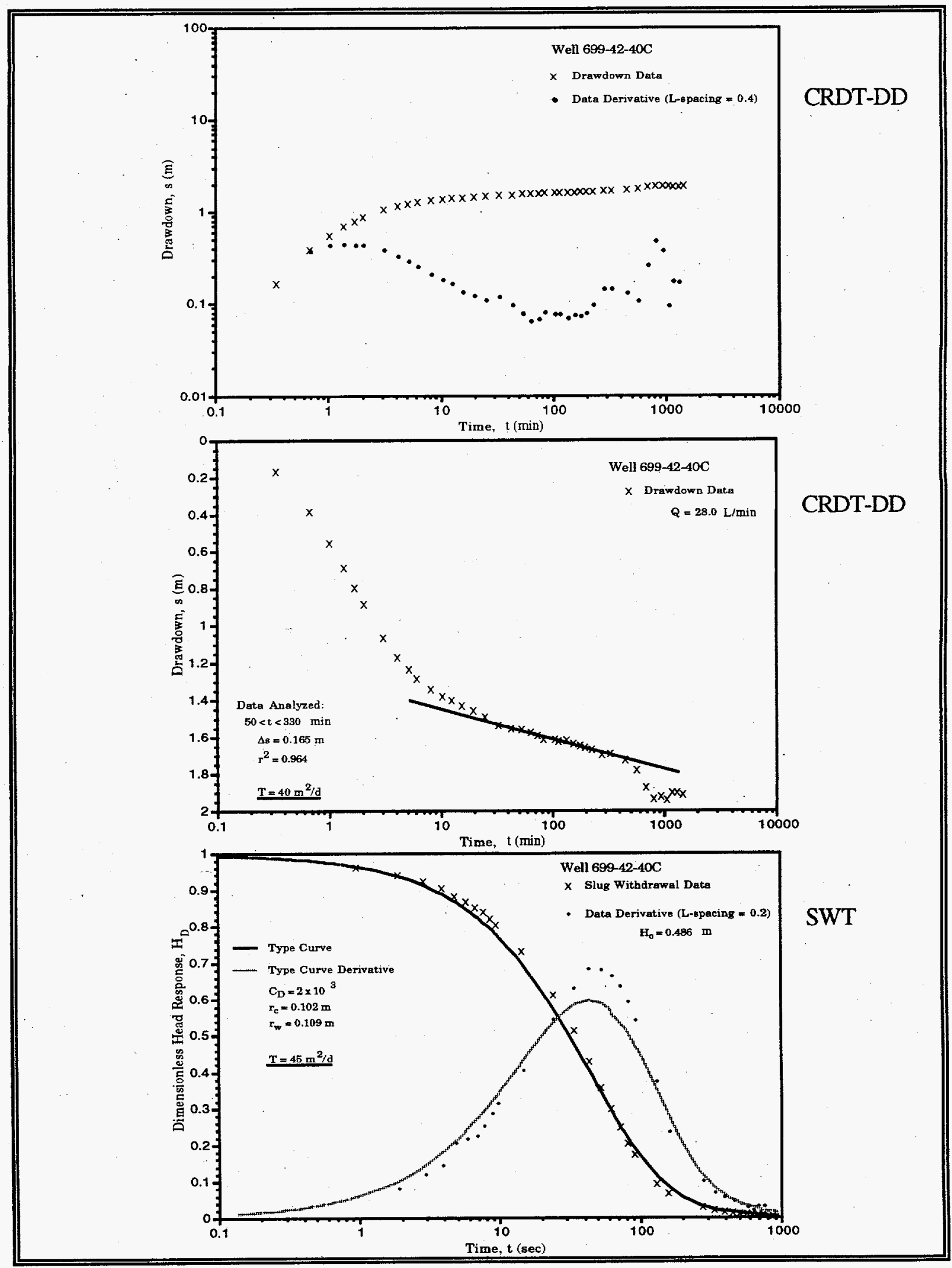

A. 37 


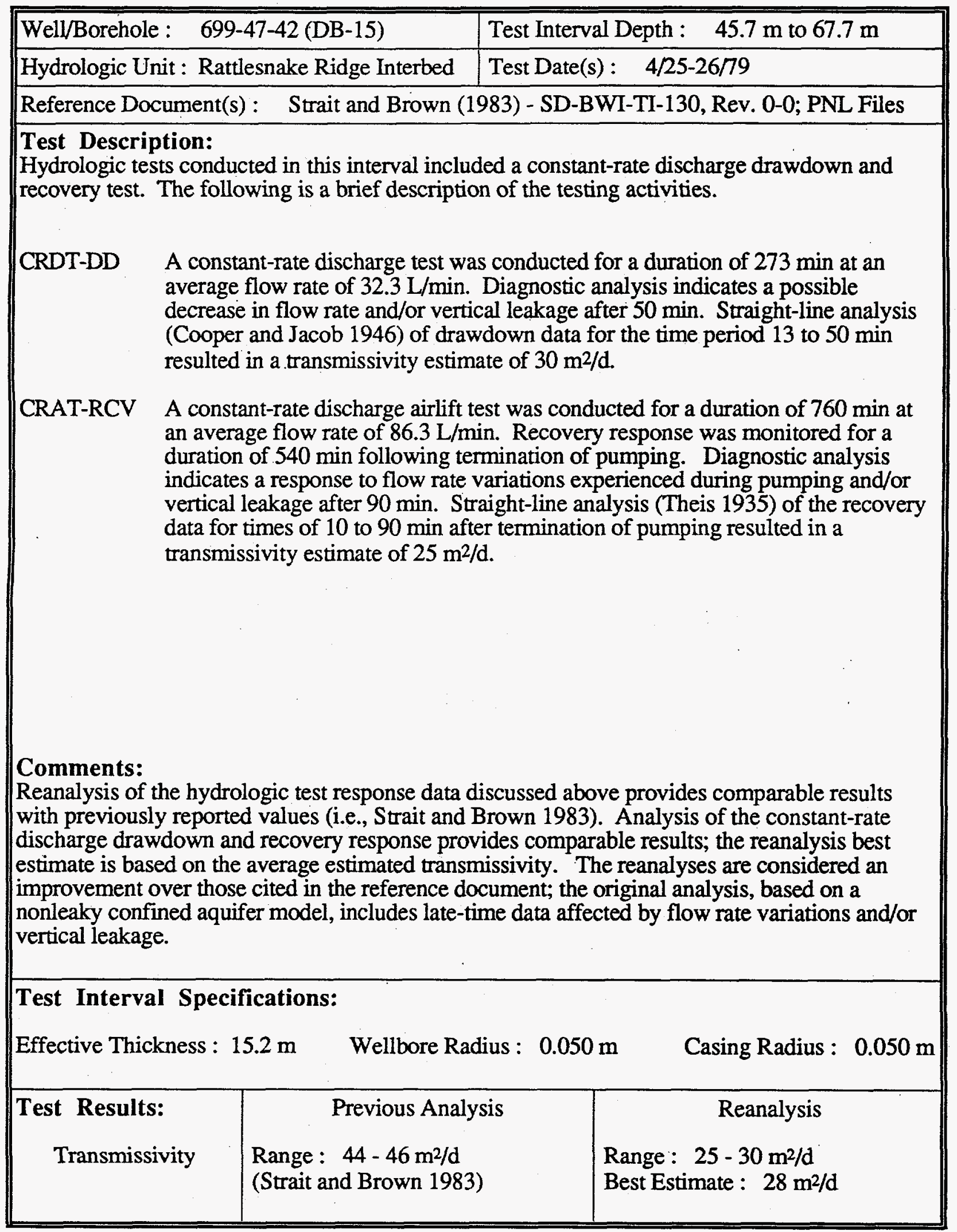




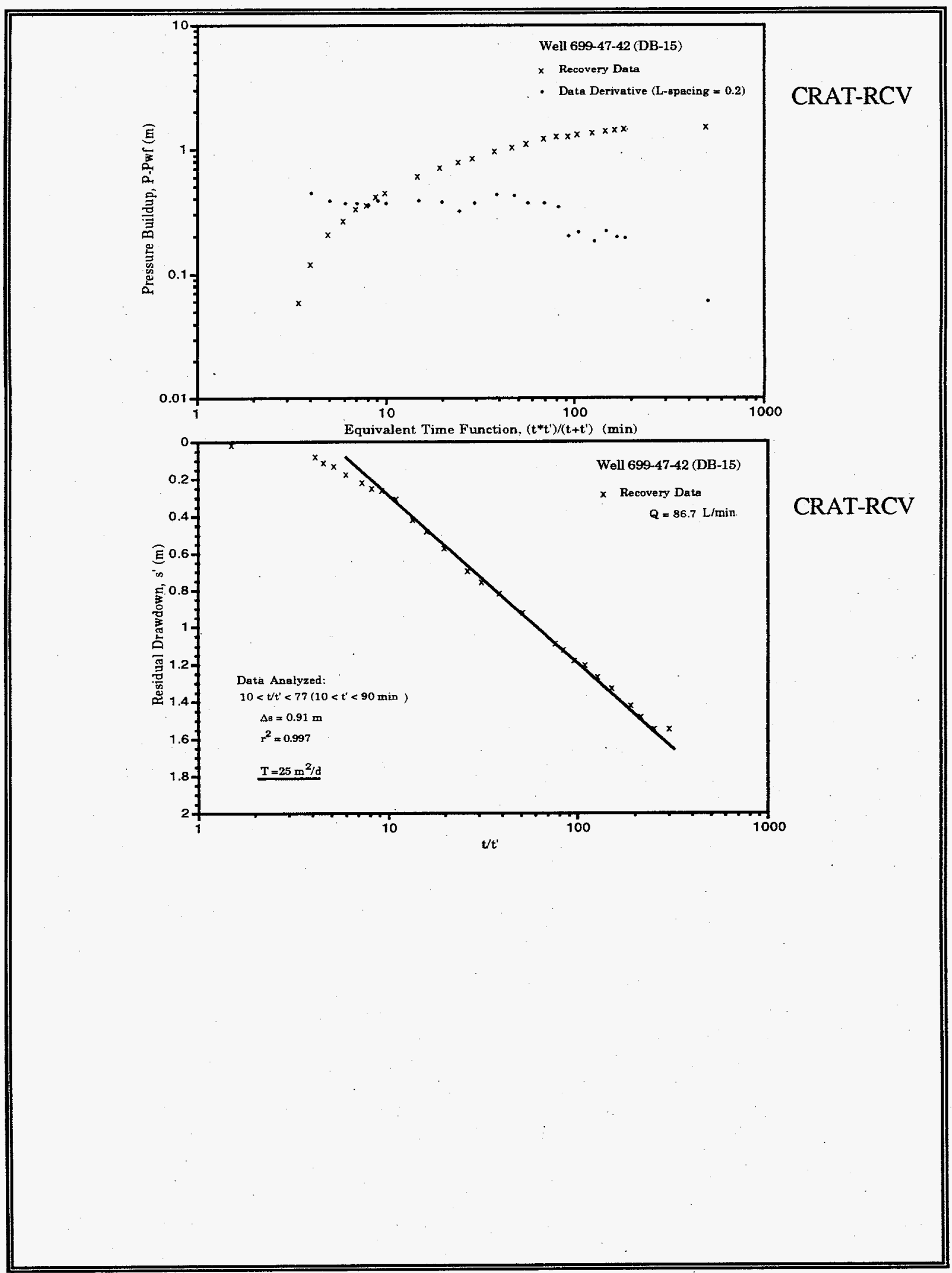




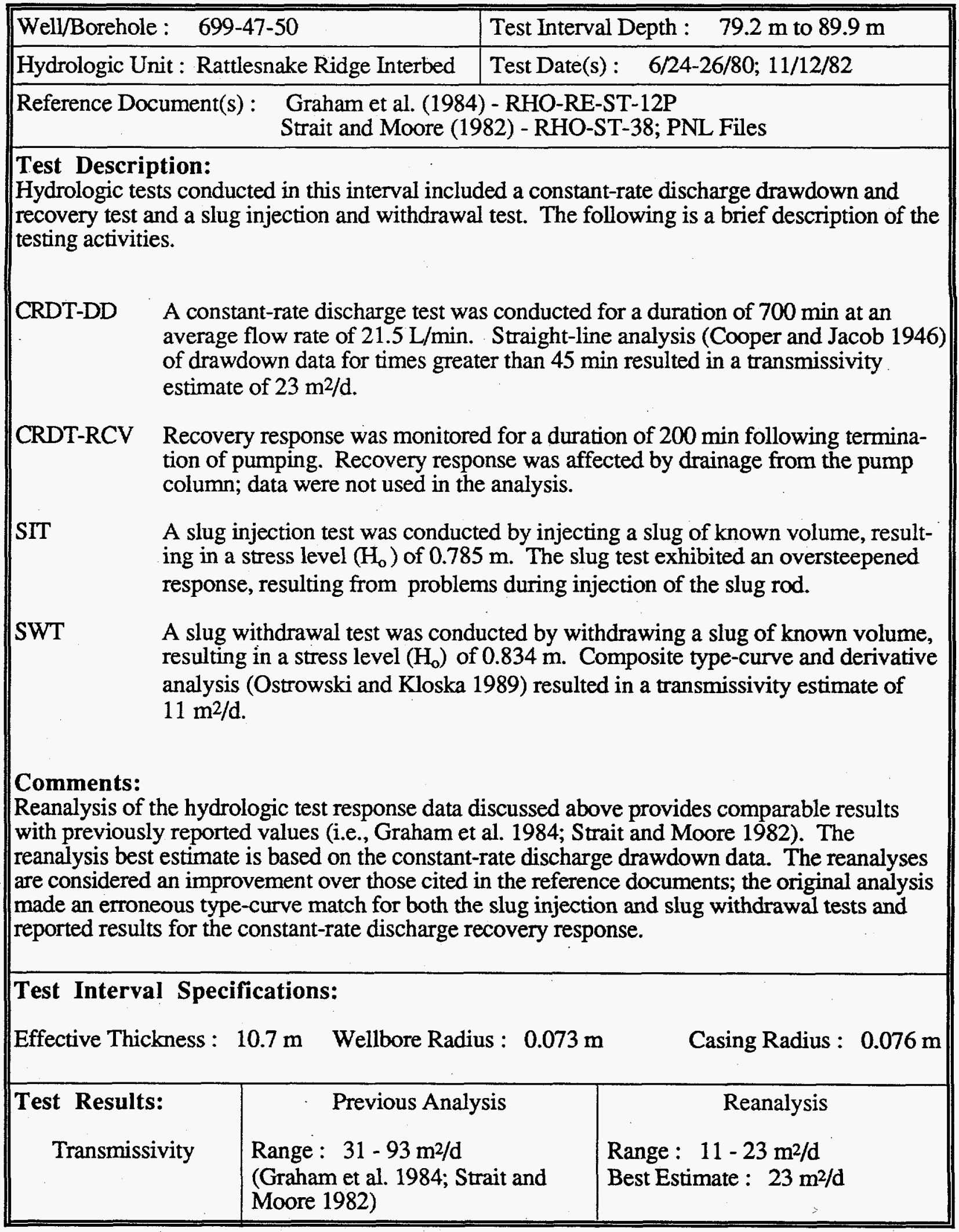




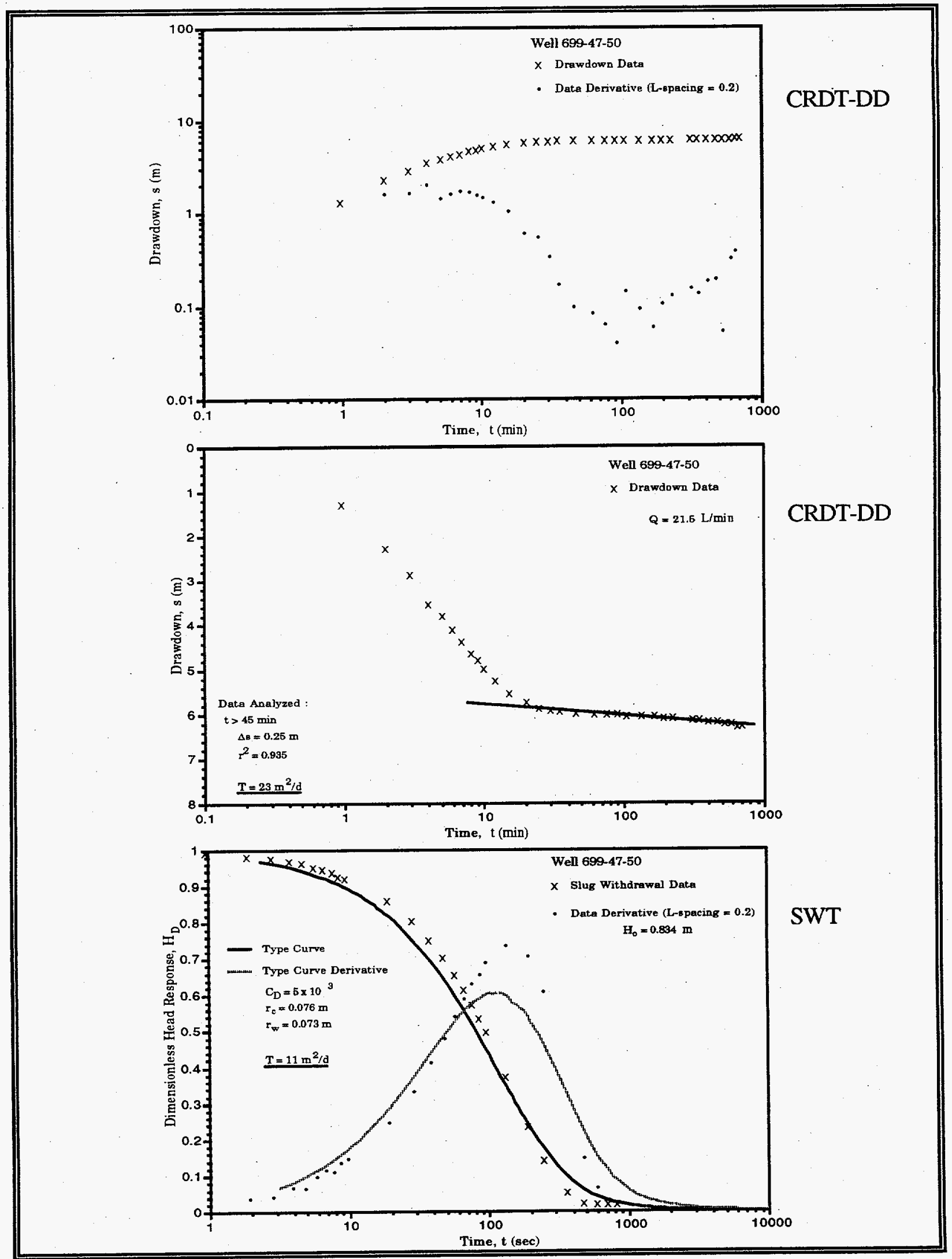

A. 41 


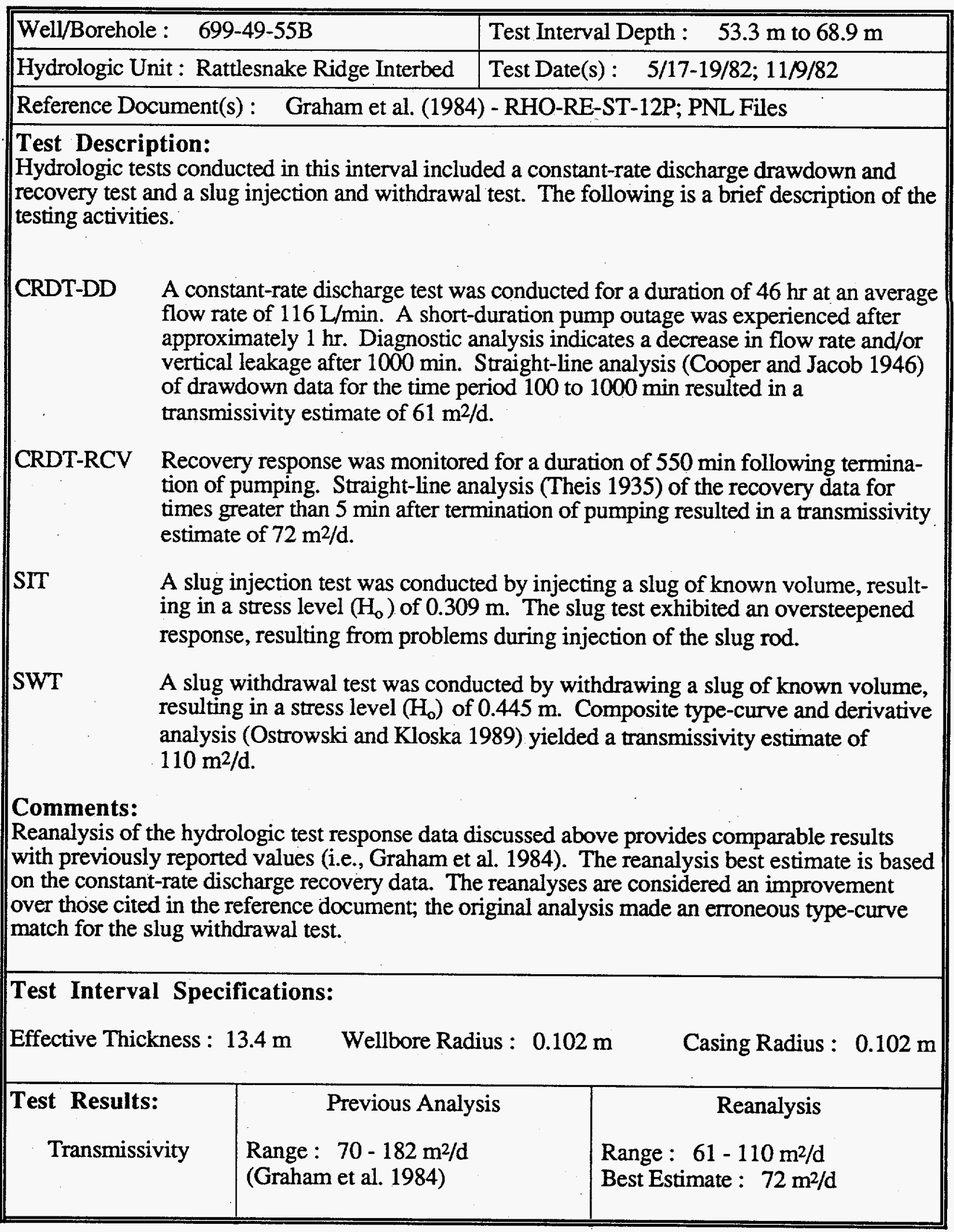




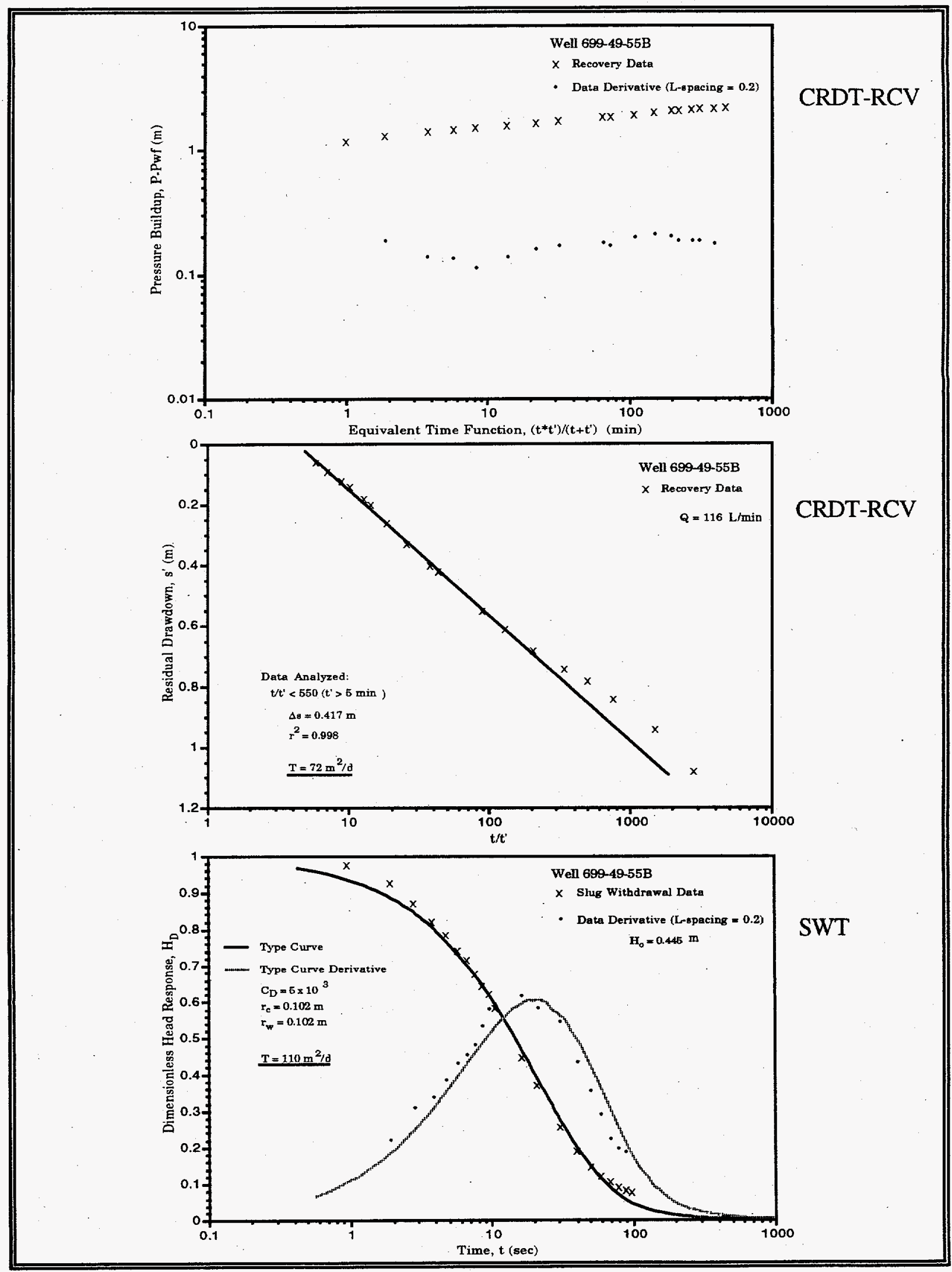

A.43 


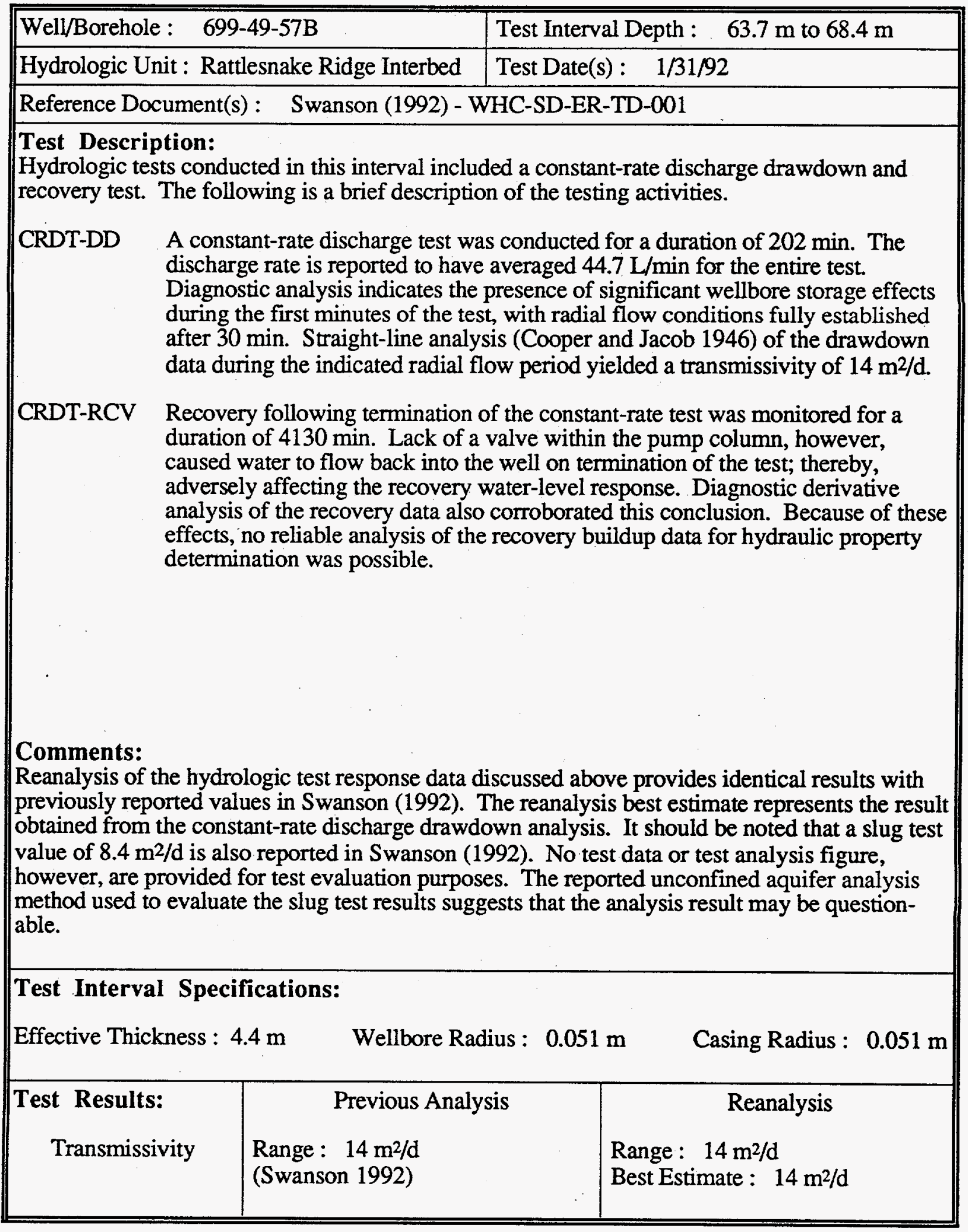




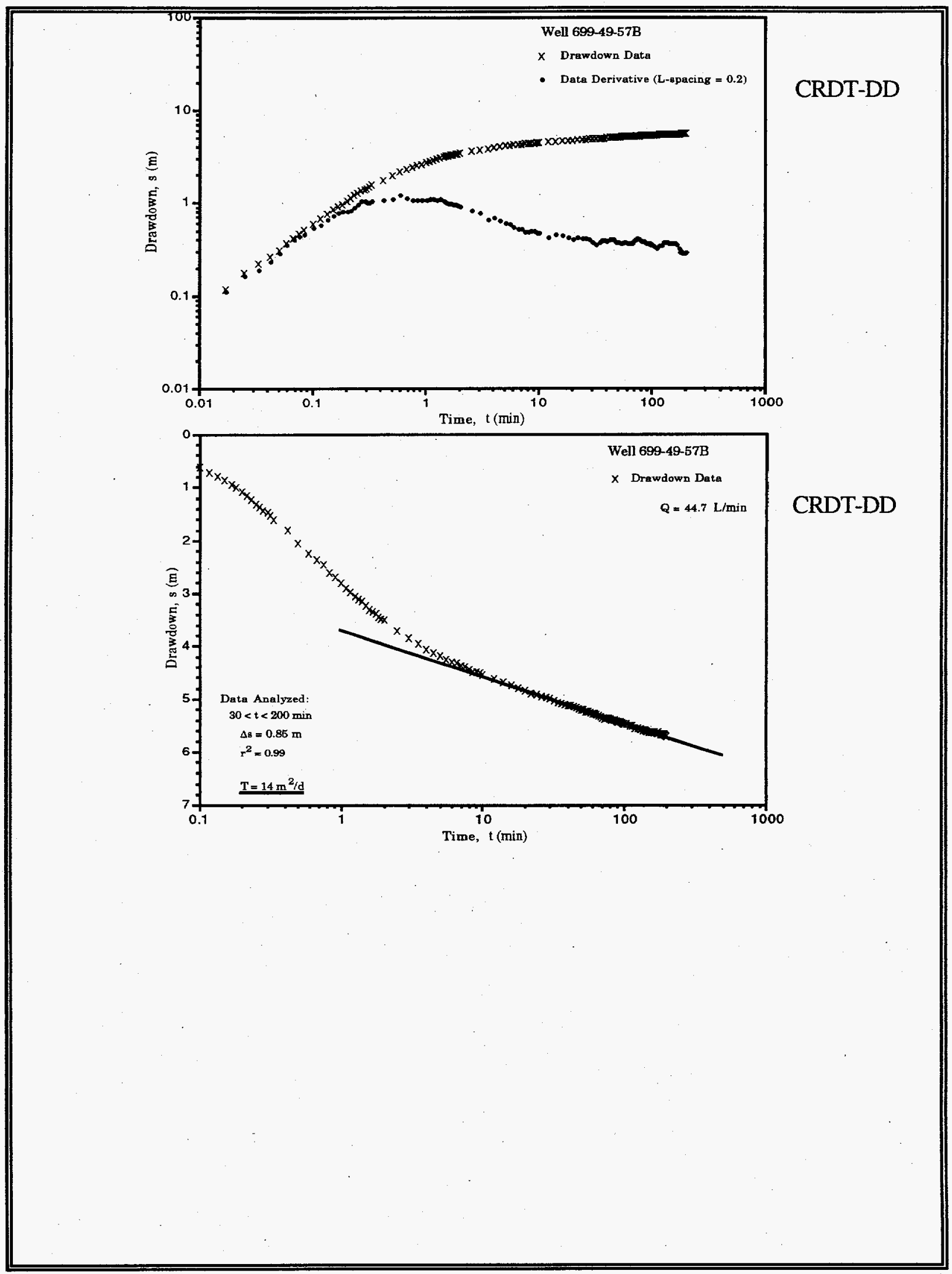




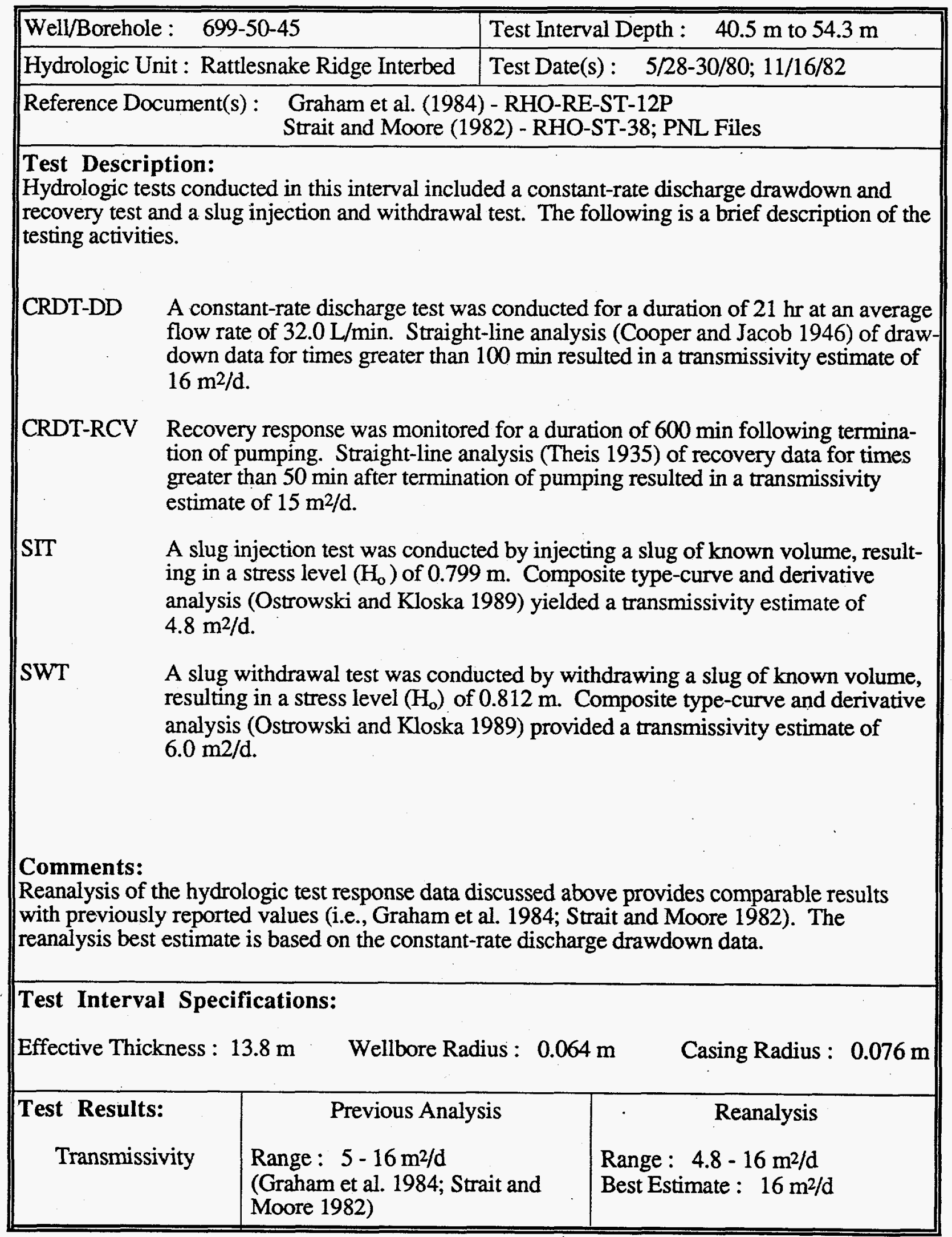




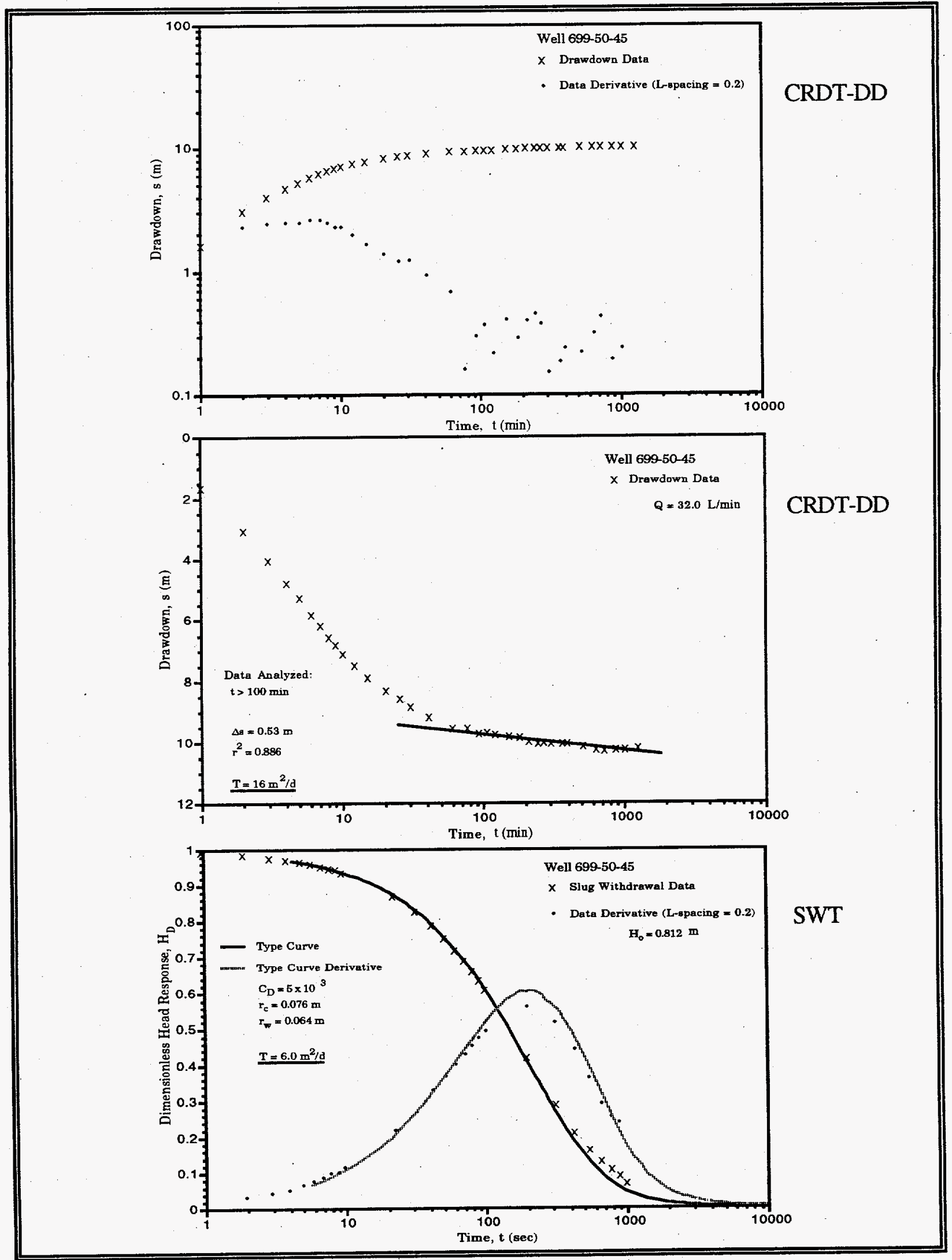

A.47 


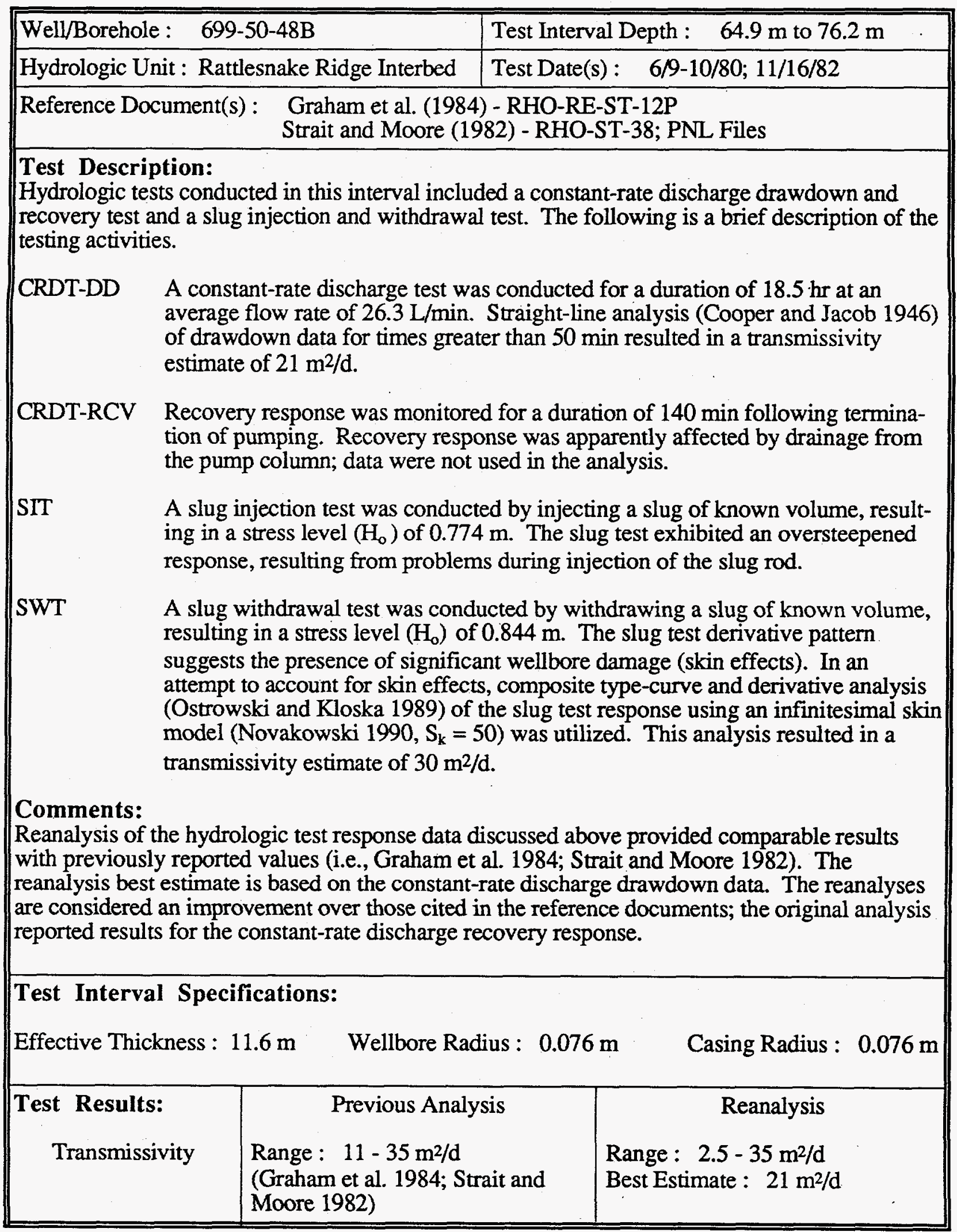




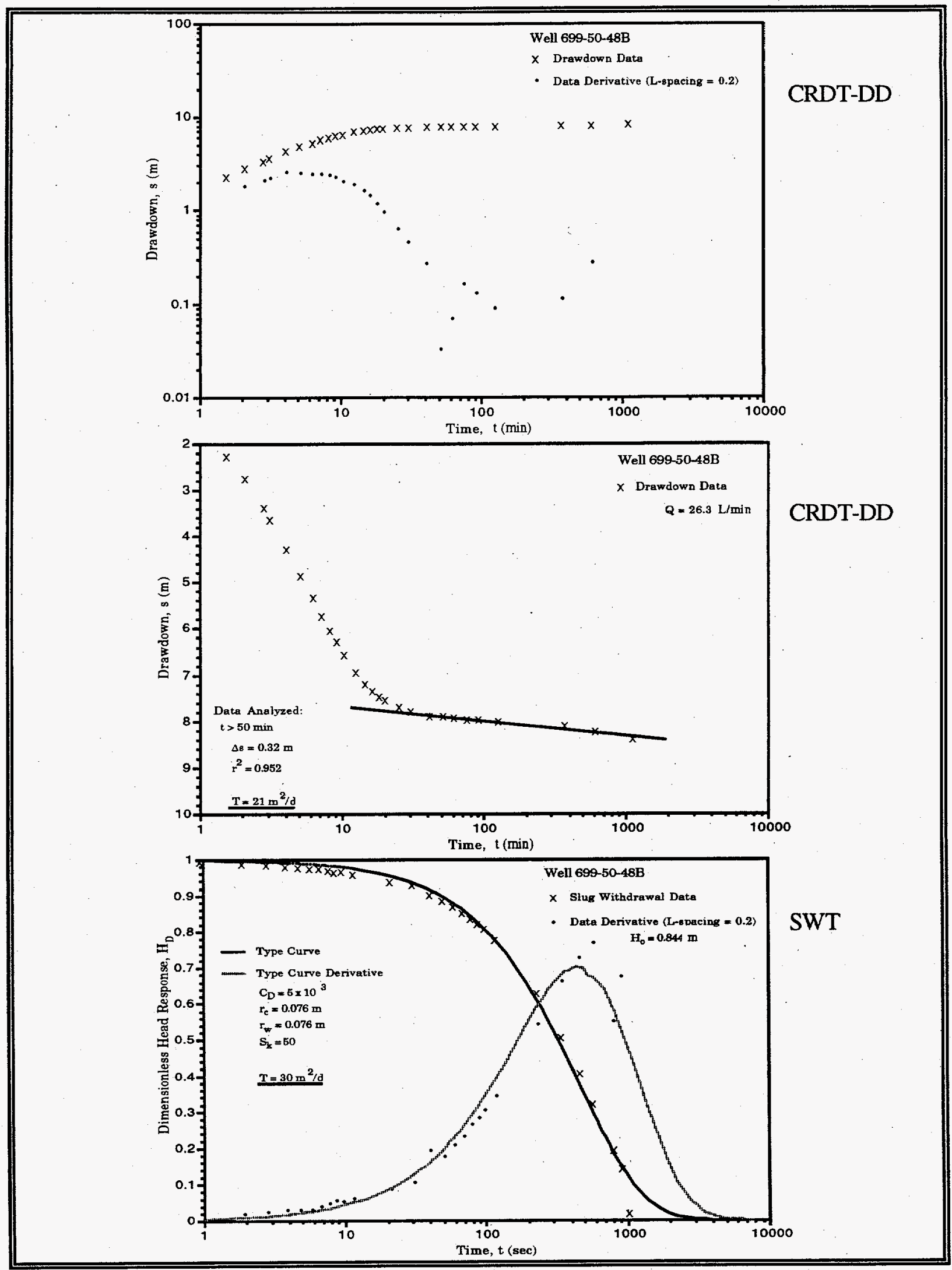

A. 49 


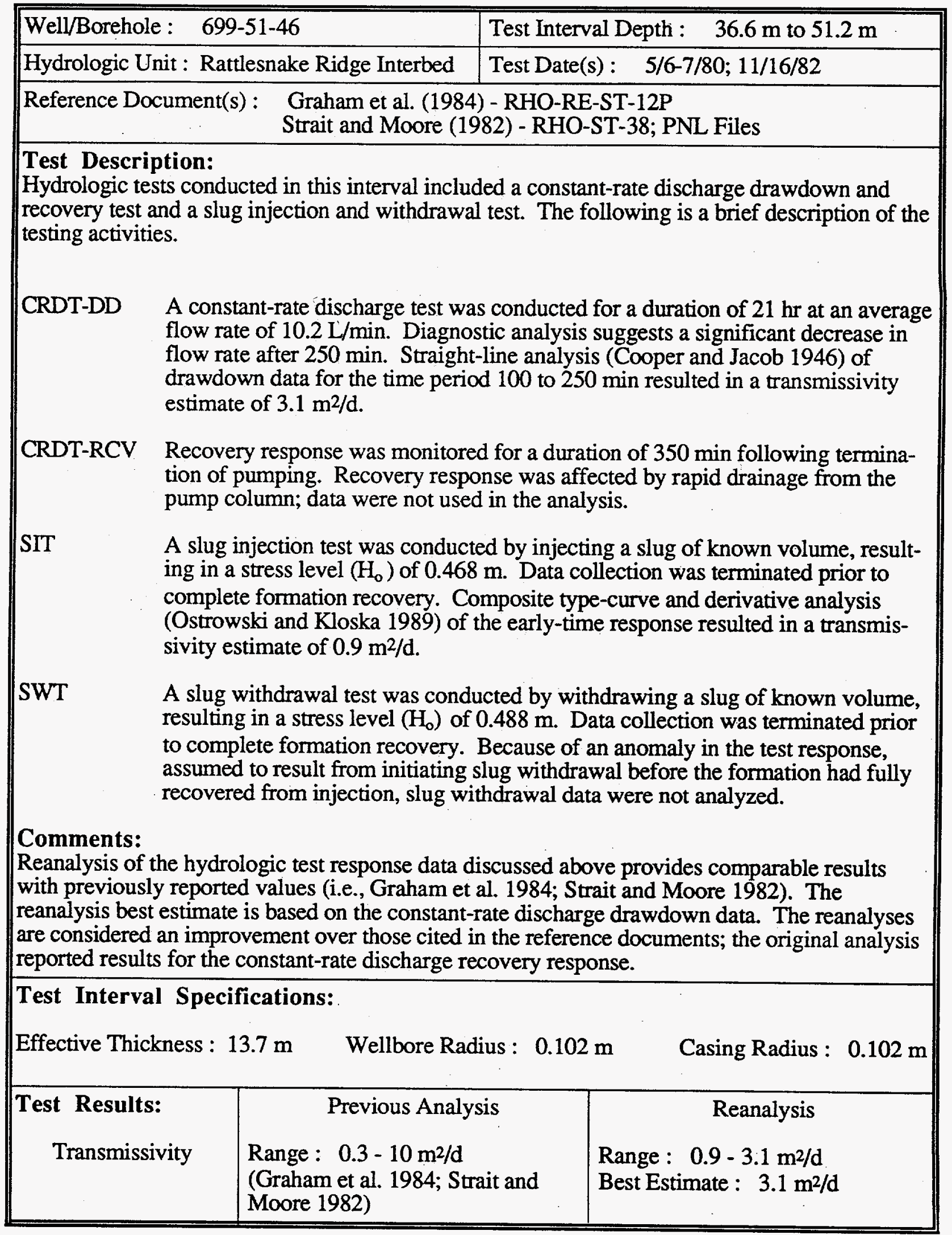




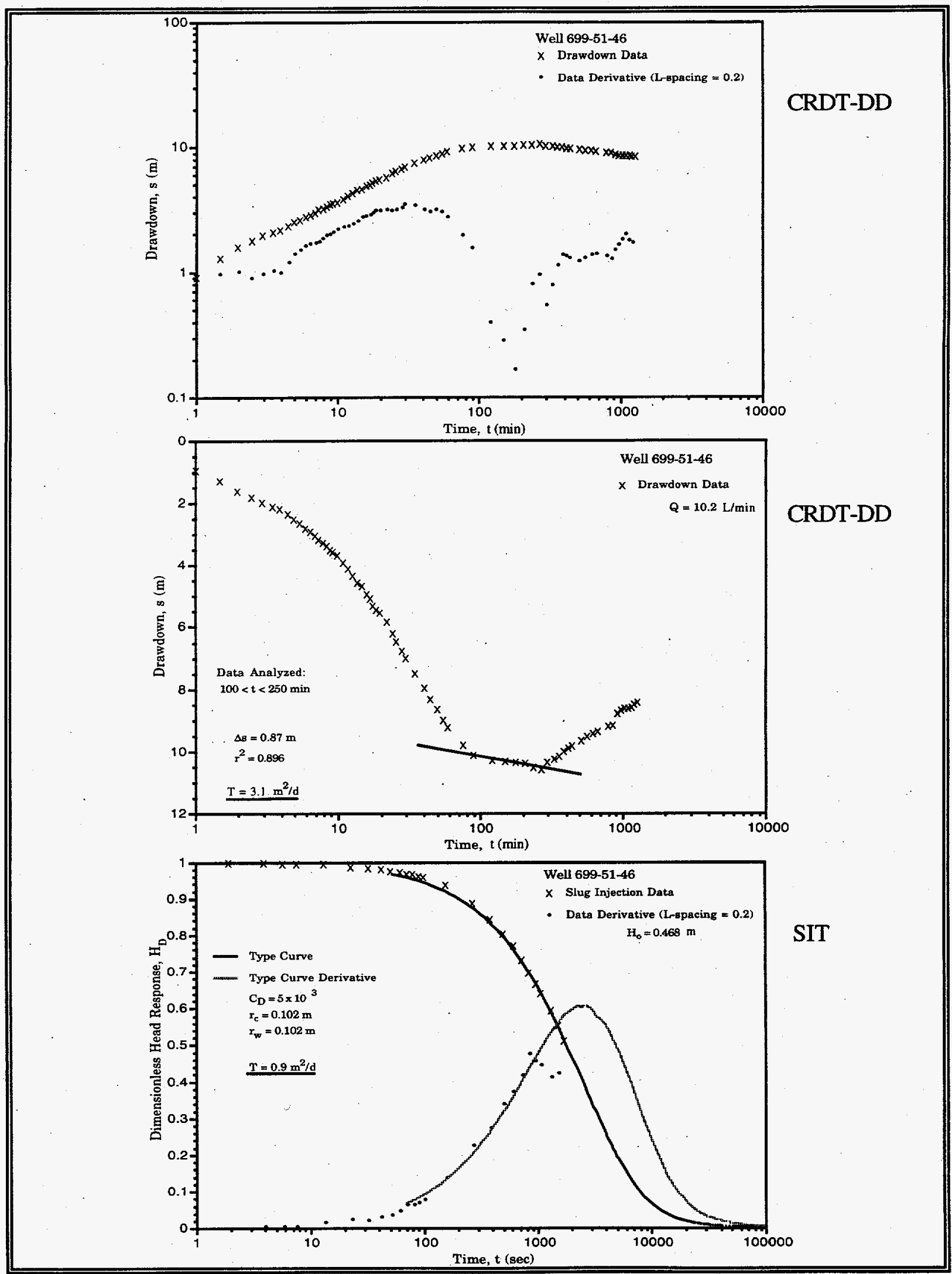

A. 51 


\begin{tabular}{|c|c|c|c|c|}
\hline \multirow{2}{*}{\multicolumn{3}{|c|}{$\begin{array}{l}\text { Well/Borehole : } 699-52-46 \mathrm{~A} \\
\text { Hydrologic Unit : Rattlesnake Ridge Interbed }\end{array}$}} & \multicolumn{2}{|c|}{ Test Interval Depth : $53.3 \mathrm{~m}$ to $68.6 \mathrm{~m}$} \\
\hline & & & \multicolumn{2}{|c|}{ Test Date(s): $\quad 5 / 8-9 / 80 ; 11 / 16 / 82$} \\
\hline \multicolumn{5}{|c|}{$\begin{array}{ll}\text { Reference Document(s): } & \text { Graham et al. (1984) - RHO-RE-ST-12P } \\
\text { Strait and Moore (1982) - RHO-ST-38; PNL Files }\end{array}$} \\
\hline \multicolumn{5}{|c|}{$\begin{array}{l}\text { Test Description: } \\
\text { Hydrologic tests conducted in this interval included a constant-rate discharge drawdown and } \\
\text { recovery test and a slug injection and withdrawal test. The following is a brief description of the } \\
\text { testing activities. }\end{array}$} \\
\hline \multicolumn{5}{|l|}{ CRDT-DD } \\
\hline \multicolumn{5}{|c|}{$\begin{array}{l}\text { CRDT-RCV Recovery response was monitored for a duration of } 180 \text { min following termina- } \\
\text { tion of pumping. Diagnostic analysis of the recovery response showed the same } \\
\text { late-time deflection observed during drawdown. Straight-line analysis (Theis } \\
\text { 1935) of recovery data for times of } 20 \text { to } 50 \mathrm{~min} \text { after termination of pumping } \\
\text { resulted in a transmissivity estimate of } 16 \mathrm{~m}^{2} / \mathrm{d} \text {. }\end{array}$} \\
\hline \multicolumn{5}{|l|}{ SIT } \\
\hline \multicolumn{5}{|c|}{$\begin{array}{l}\text { AWT slug withdrawal test was conducted by withdrawing a slug of known volume, } \\
\text { resulting in a stress level }\left(\mathrm{H}_{\mathrm{o}}\right) \text { of } 0.432 \mathrm{~m} \text {. Composite type-curve and derivative } \\
\text { analysis (Ostrowski and Kloska 1989) resulted in a transmissivity estimate of } \\
28 \mathrm{~m}^{2} / \mathrm{d} \text {. }\end{array}$} \\
\hline \multicolumn{5}{|c|}{$\begin{array}{l}\text { Comments: } \\
\text { Reanalysis of the hydrologic test response data discussed above provides comparable results } \\
\text { with previously reported values (i.e., Graham et al. 1984; Strait and Moore 1982). Analysis of } \\
\text { the constant-rate discharge and slug test response provides comparable results; the reanalysis } \\
\text { best estimate is based on the average estimated transmissivity. }\end{array}$} \\
\hline \multicolumn{5}{|c|}{$\begin{array}{l}\text { Test Interval Specifications: } \\
\text { Effective Thickness : } 18.3 \mathrm{~m} \quad \text { Wellbore R }\end{array}$} \\
\hline \multicolumn{2}{|c|}{$\begin{array}{l}\text { Test Results: } \\
\text { Transmissivity }\end{array}$} & $\begin{array}{l}\text { Previous Anal } \\
\text { Range : } 13-21 \mathrm{~m}^{2} / \mathrm{d} \\
\text { (Graham et al. } 1984 ; \mathrm{S} \\
\text { Moore 1982) }\end{array}$ & ais and & $\begin{array}{l}\text { Reanalysis } \\
\text { Range : } 16-28 \mathrm{~m}^{2} / \mathrm{d} \\
\text { Best Estimate : } 20 \mathrm{~m}^{2} / \mathrm{d}\end{array}$ \\
\hline
\end{tabular}




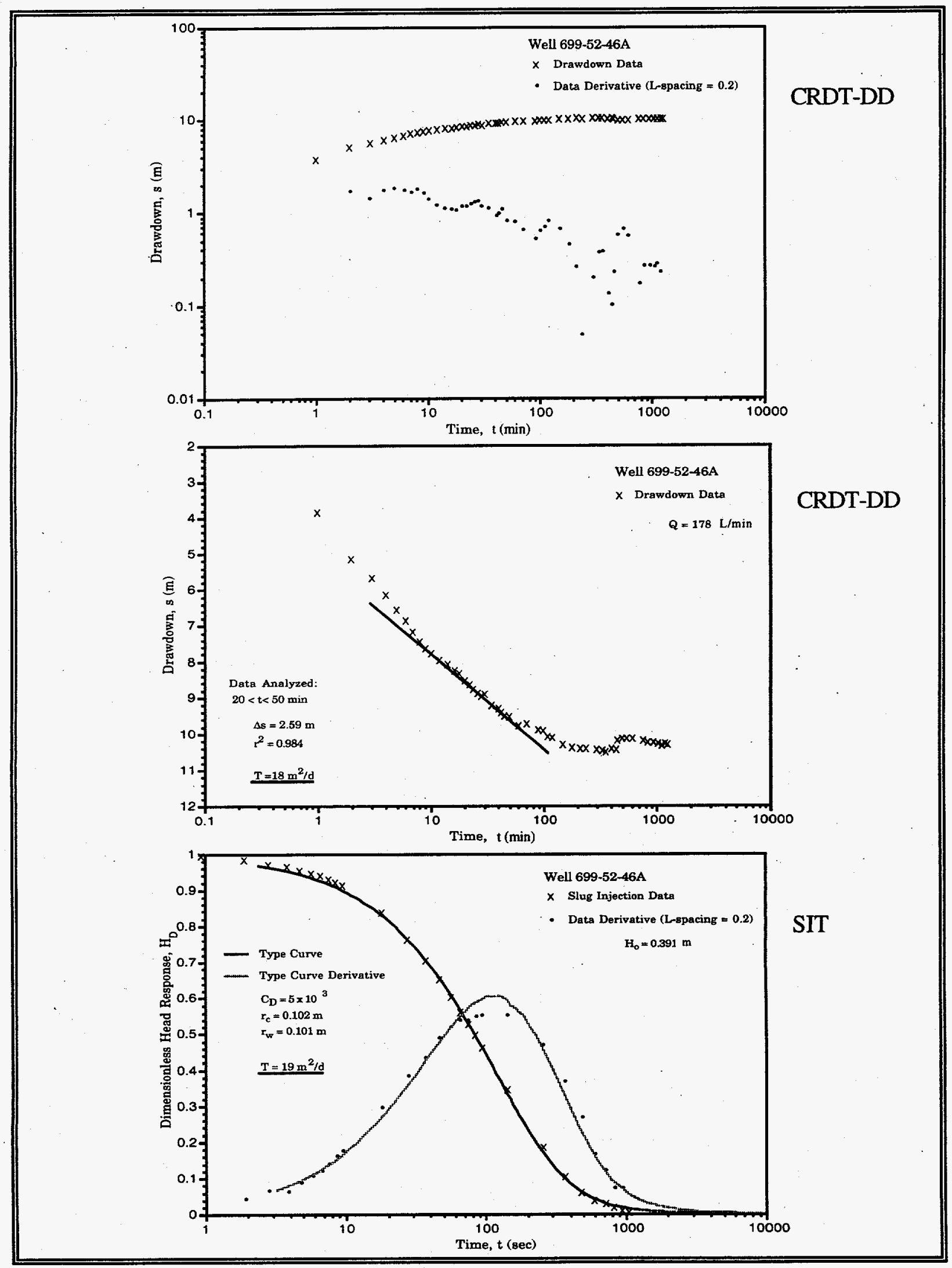

A. 53 


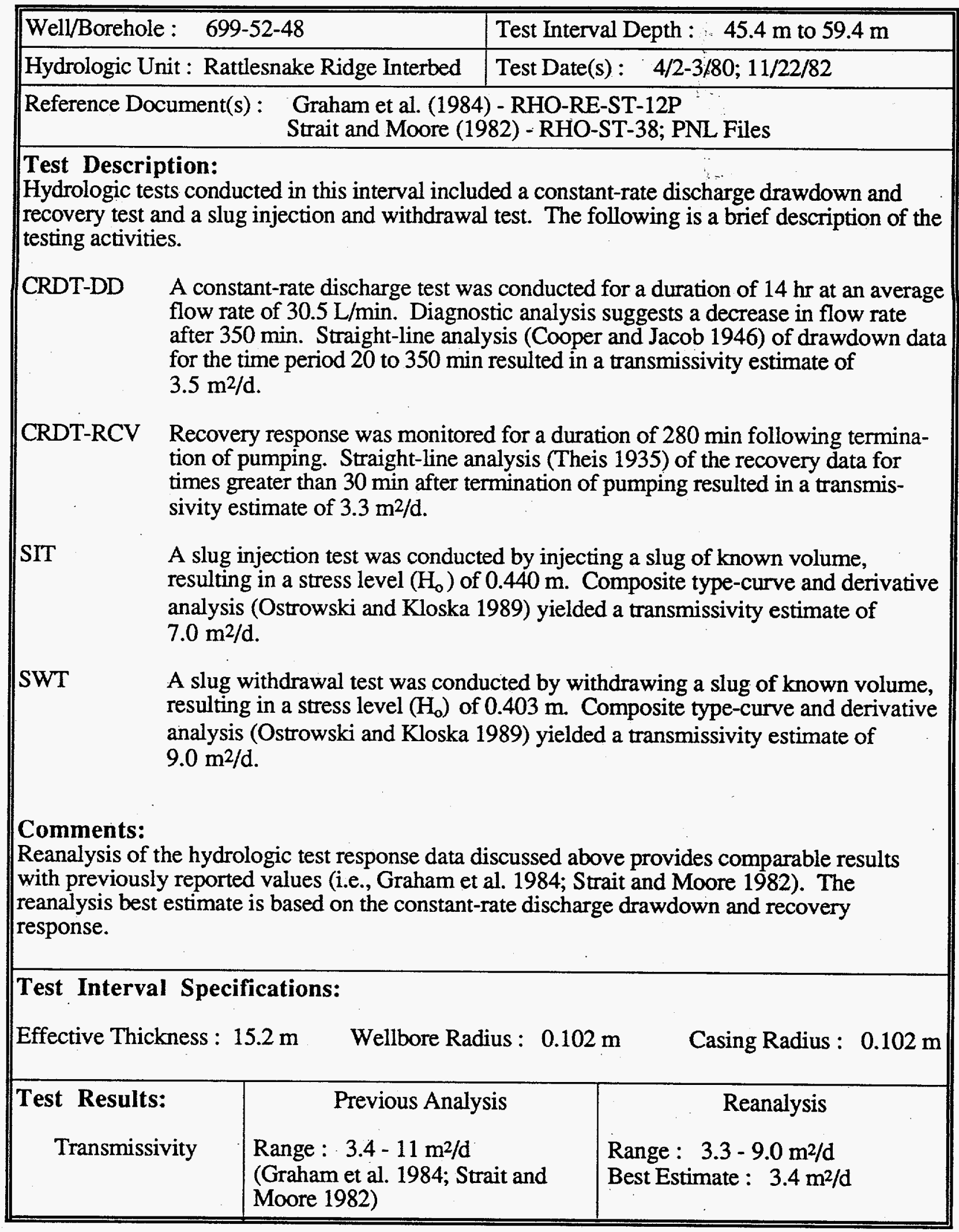




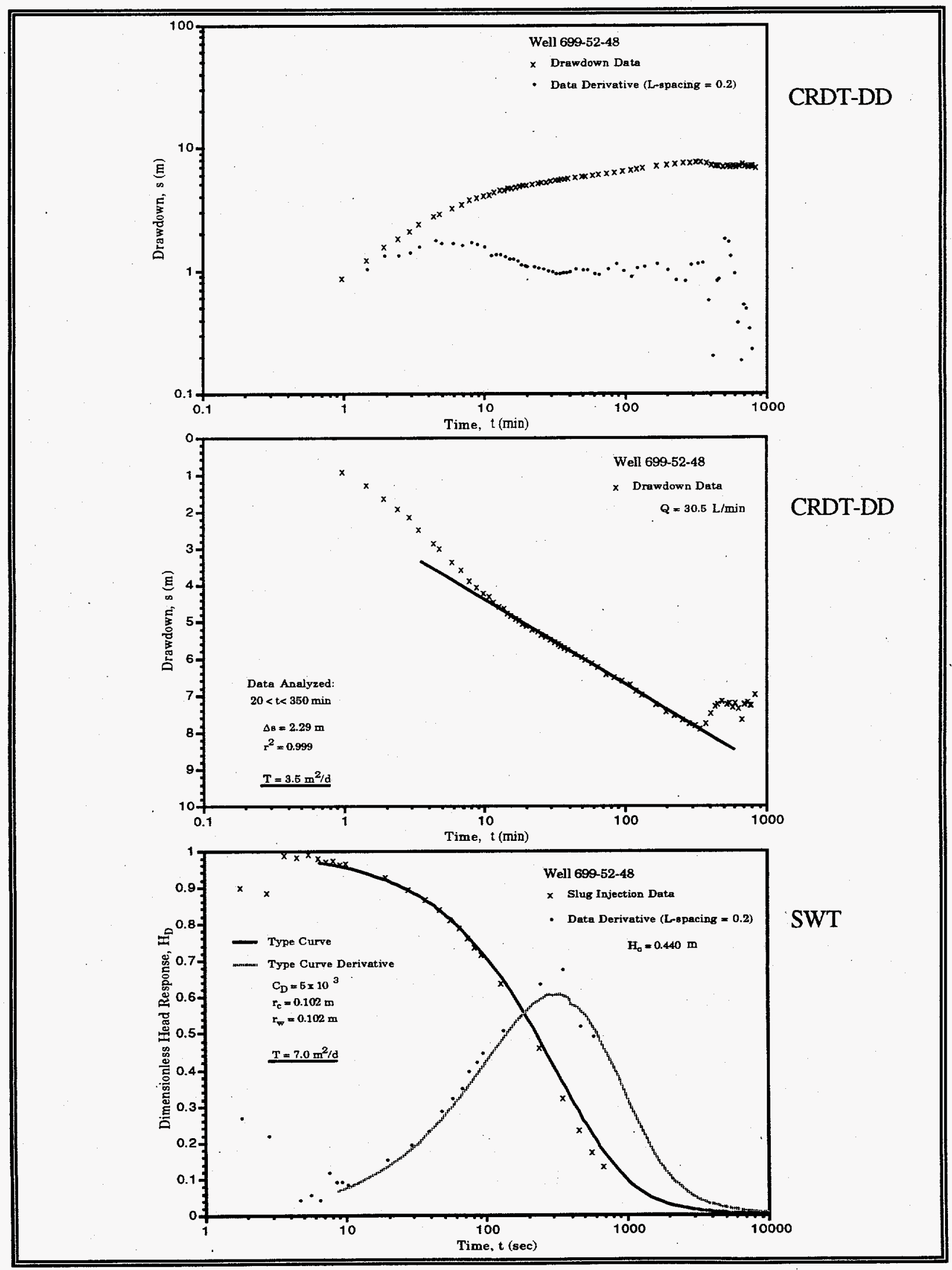

A.55 


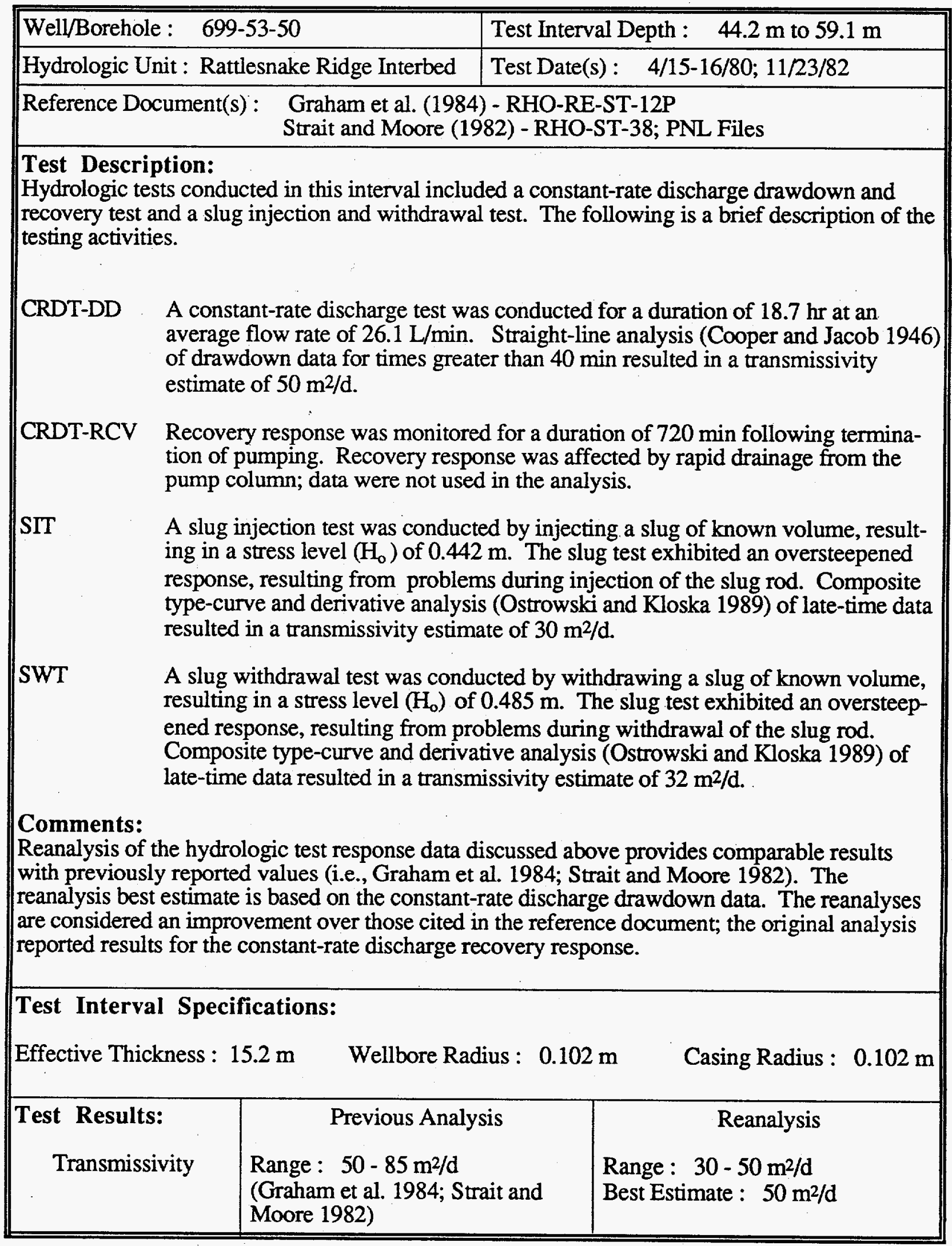




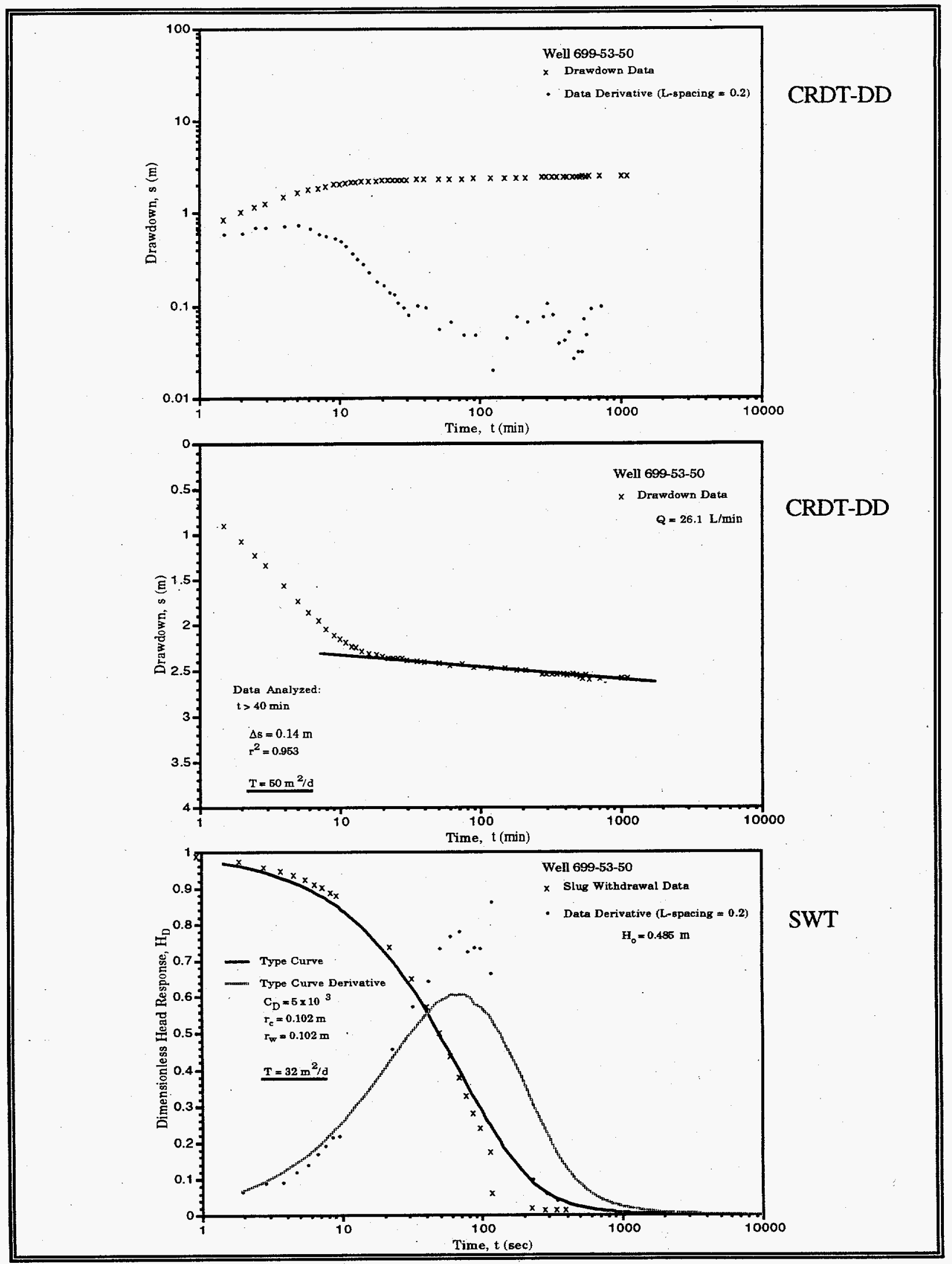

A. 57 


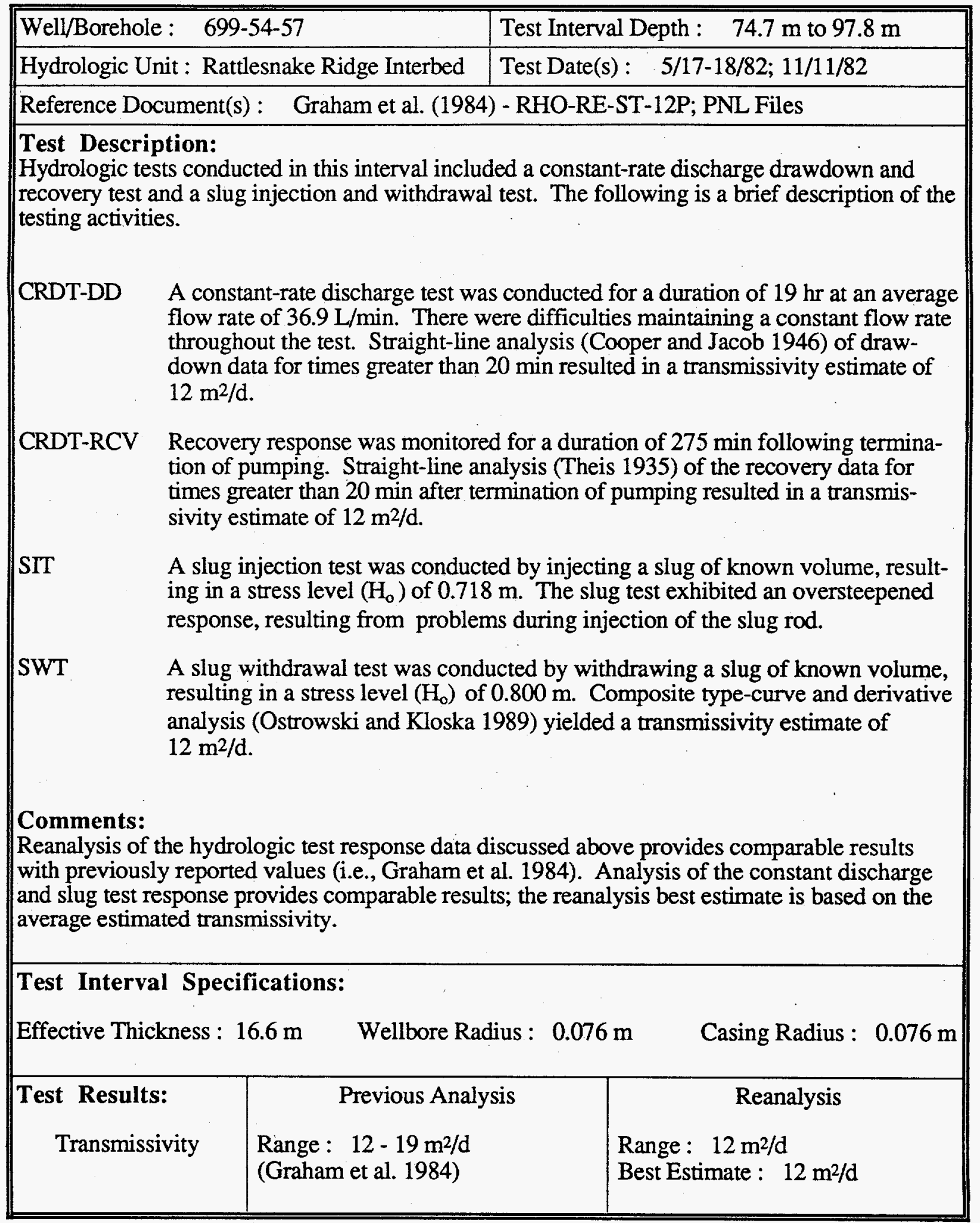




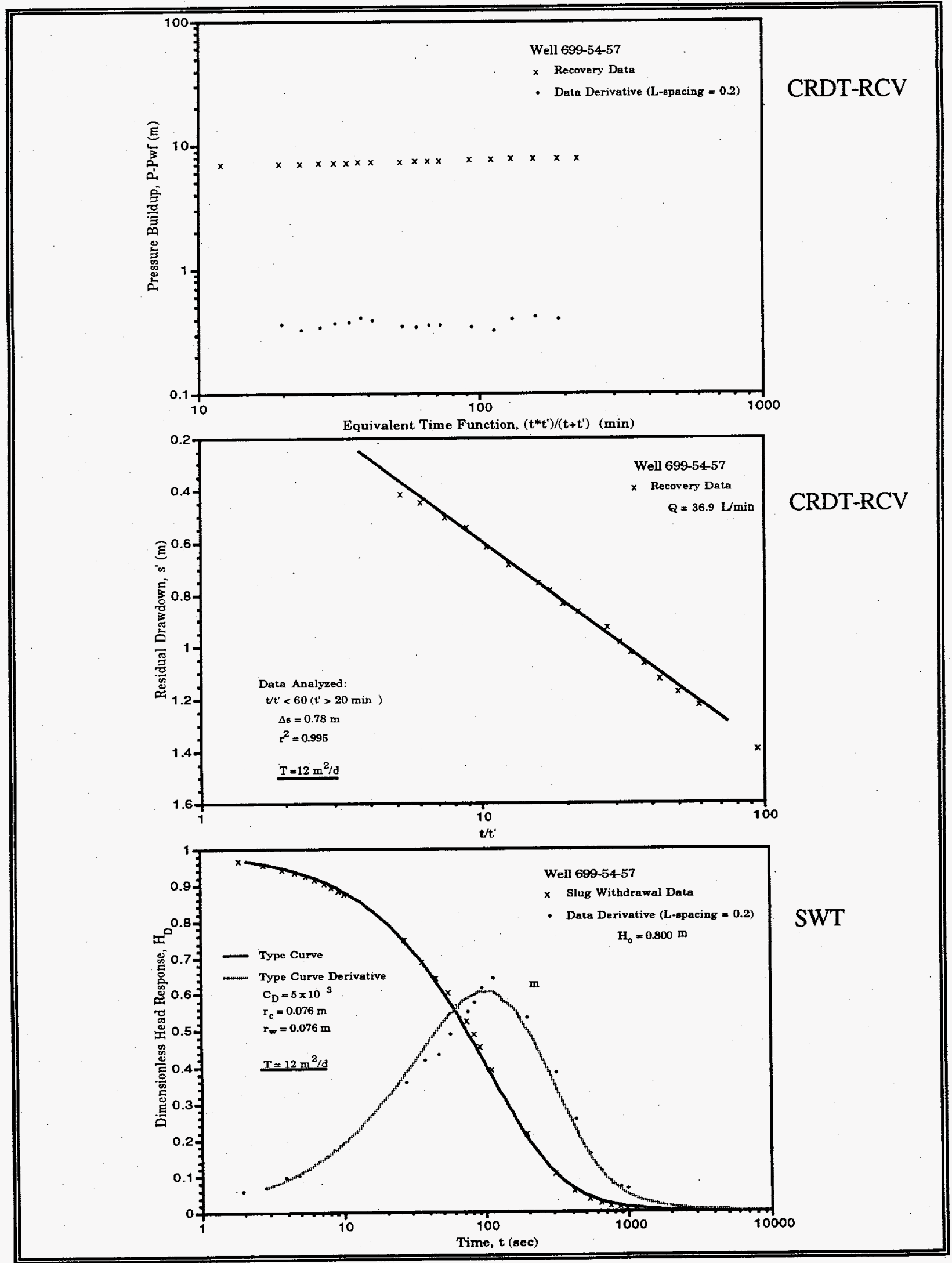

A. 59 


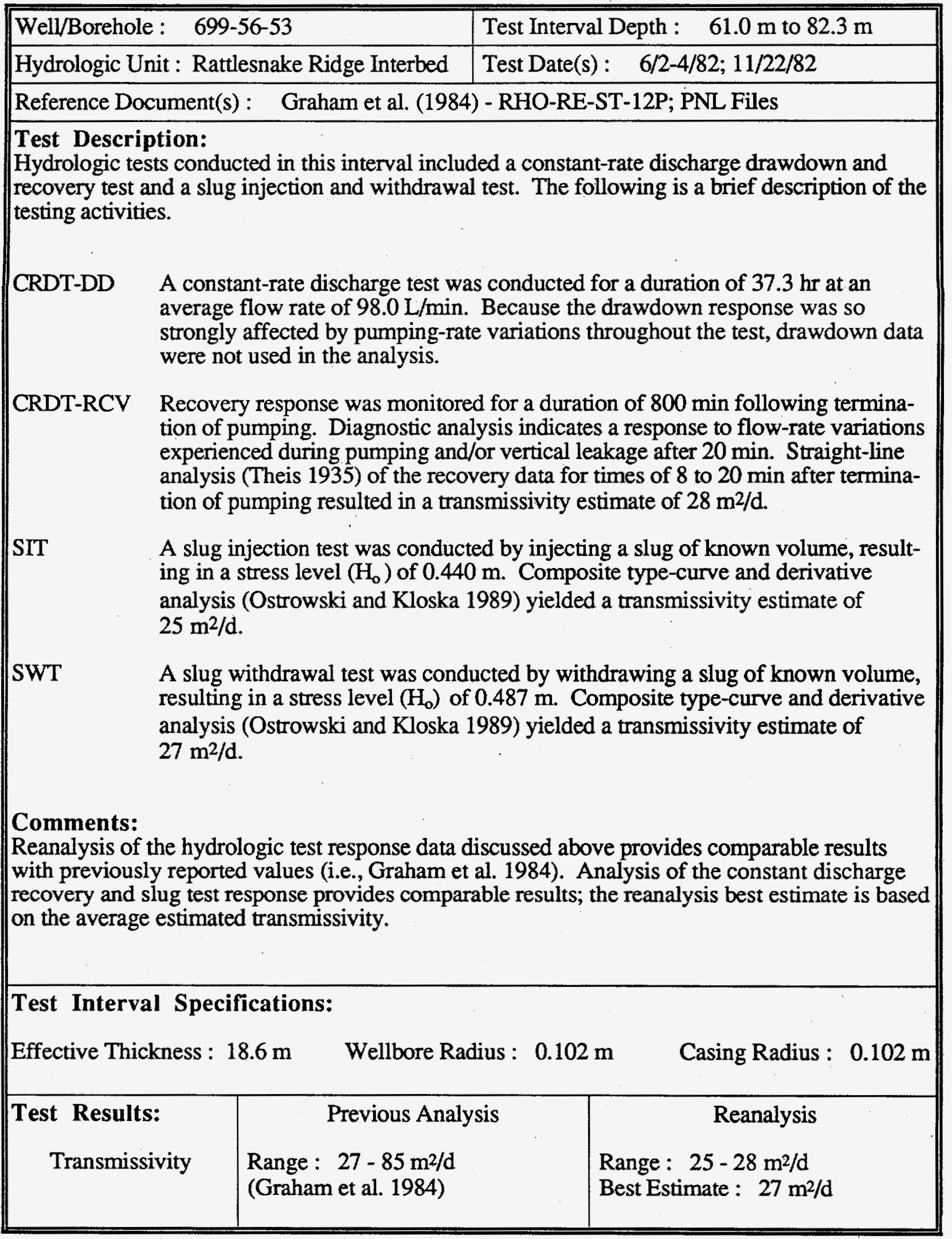




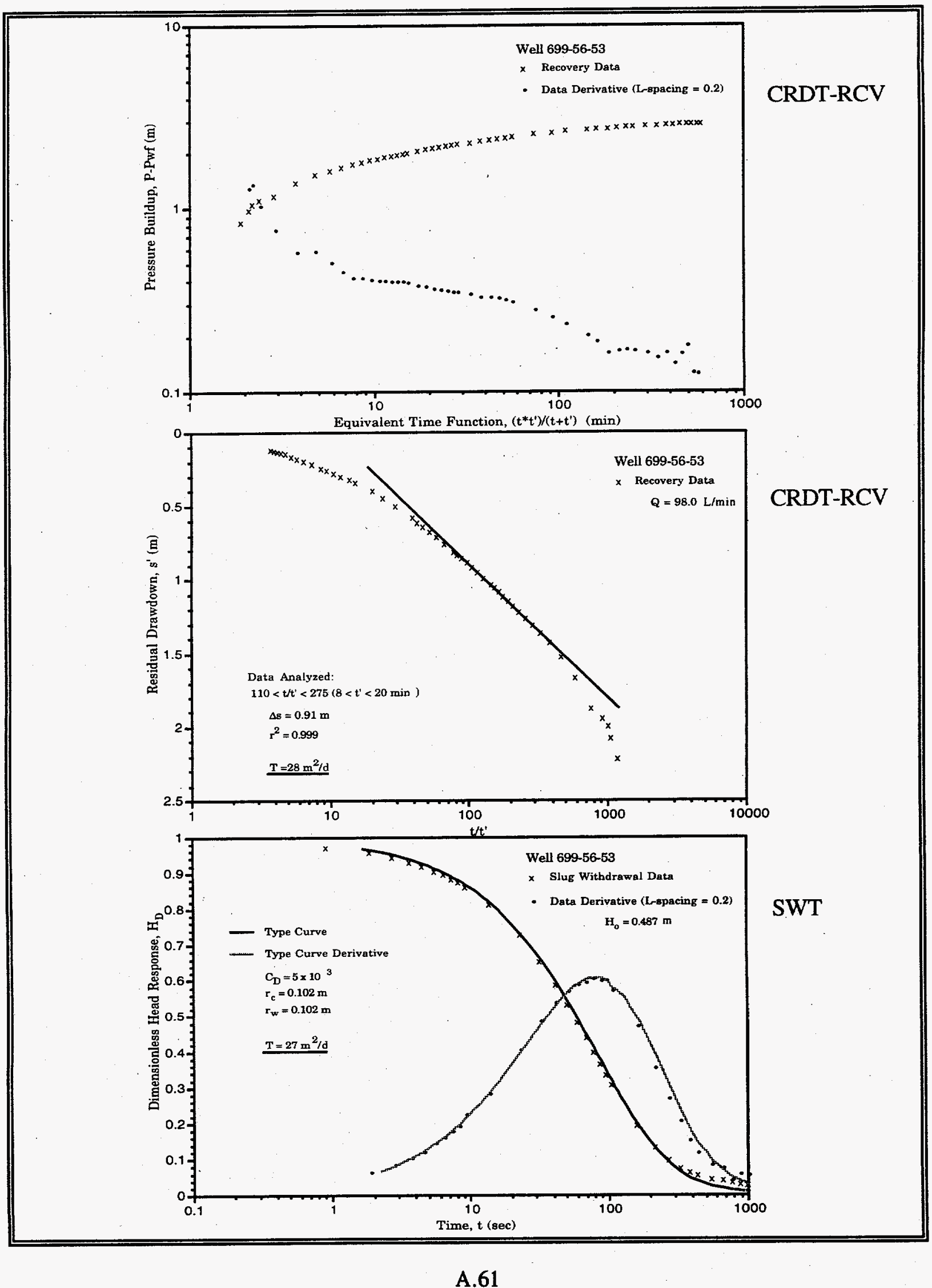




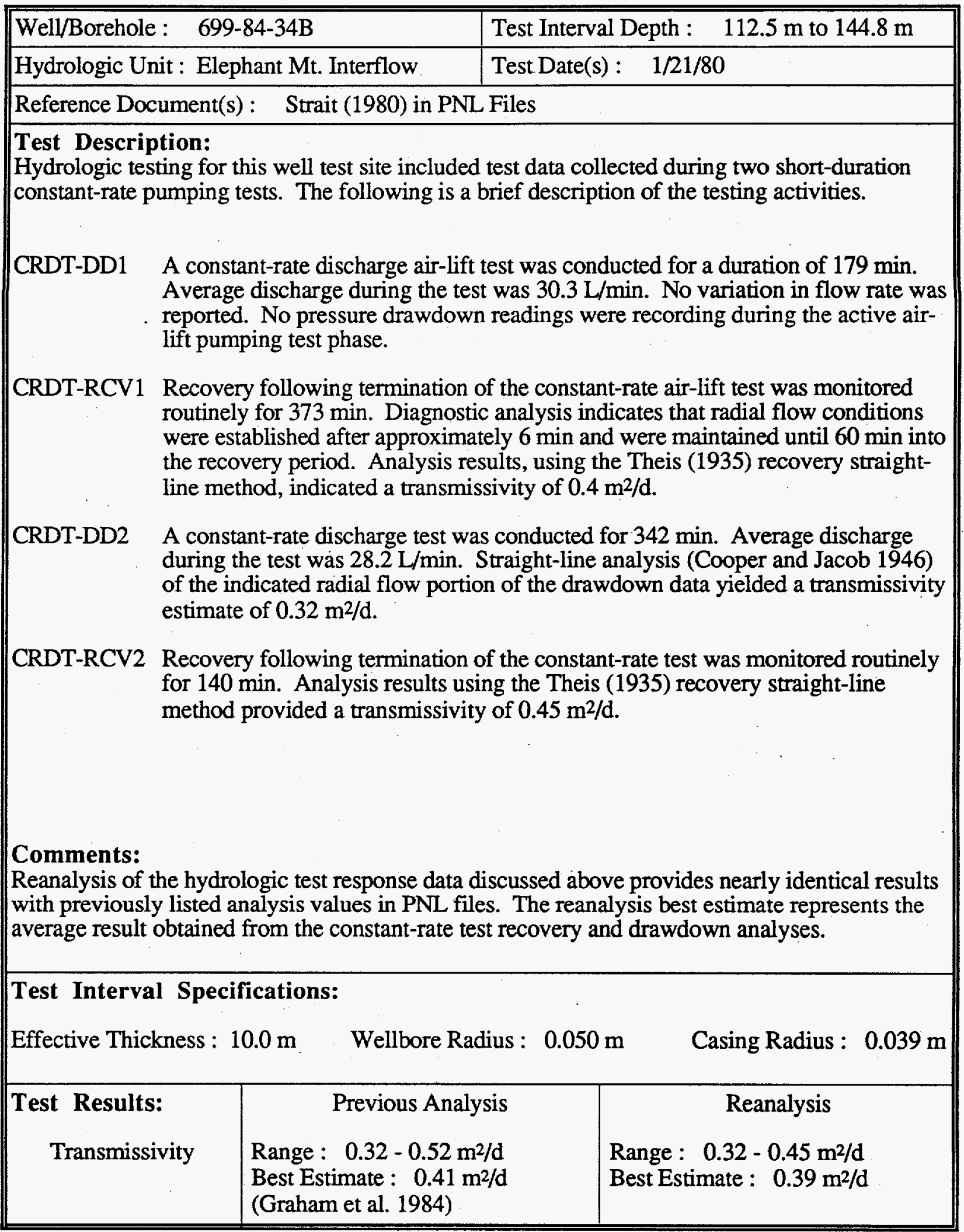




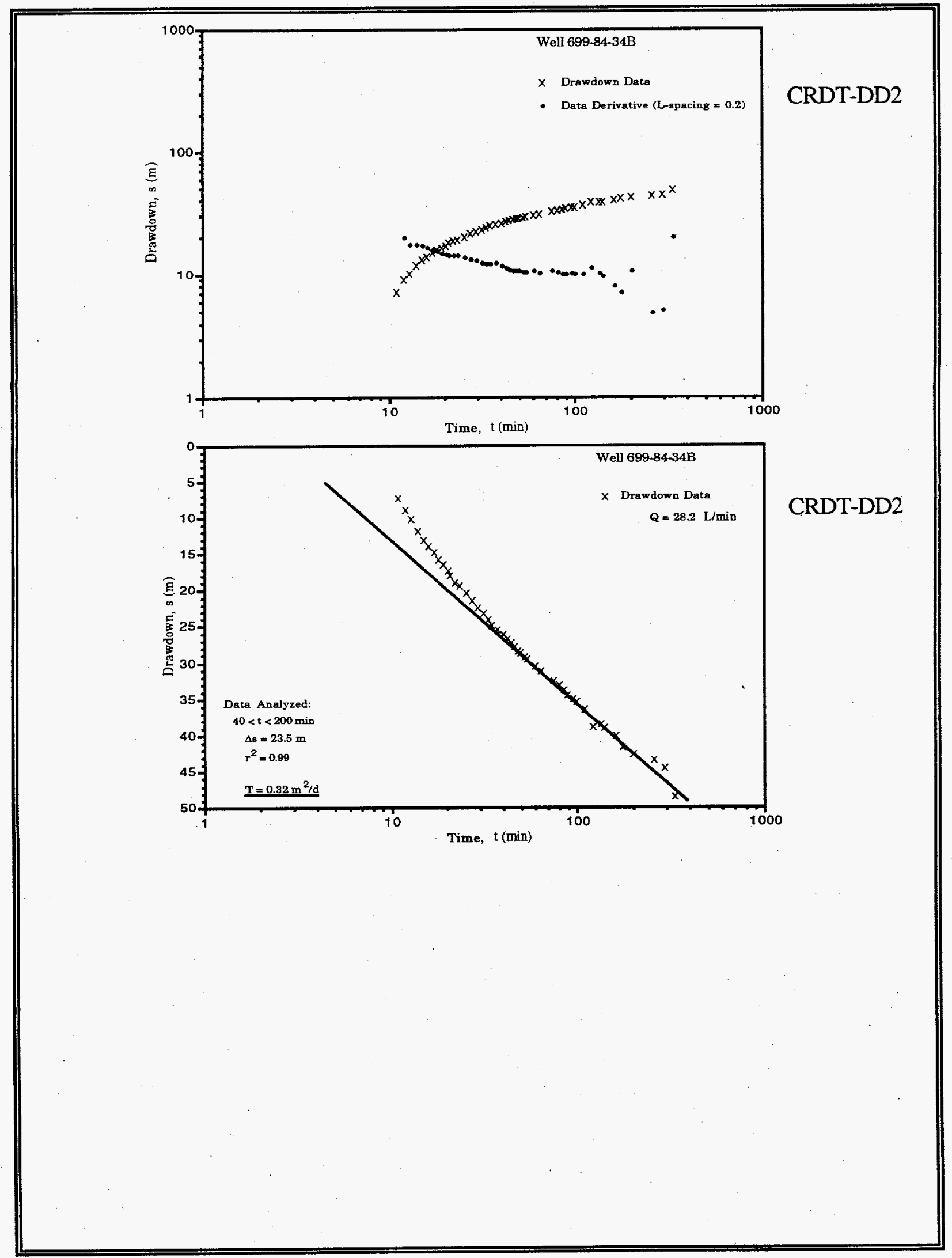




\begin{tabular}{|l|l|l||}
\hline Well/Borehole : $\quad$ 699-84-34B & Test Interval Depth : $144.8 \mathrm{~m}$ to $164.0 \mathrm{~m}$ \\
\hline Hydrologic Unit : Rattlesnake Ridge Interbed & Test Date(s) : $1 / 15-16 / 80$ \\
\hline Reference Document(s) : Strait (1980) in PNL Files
\end{tabular}




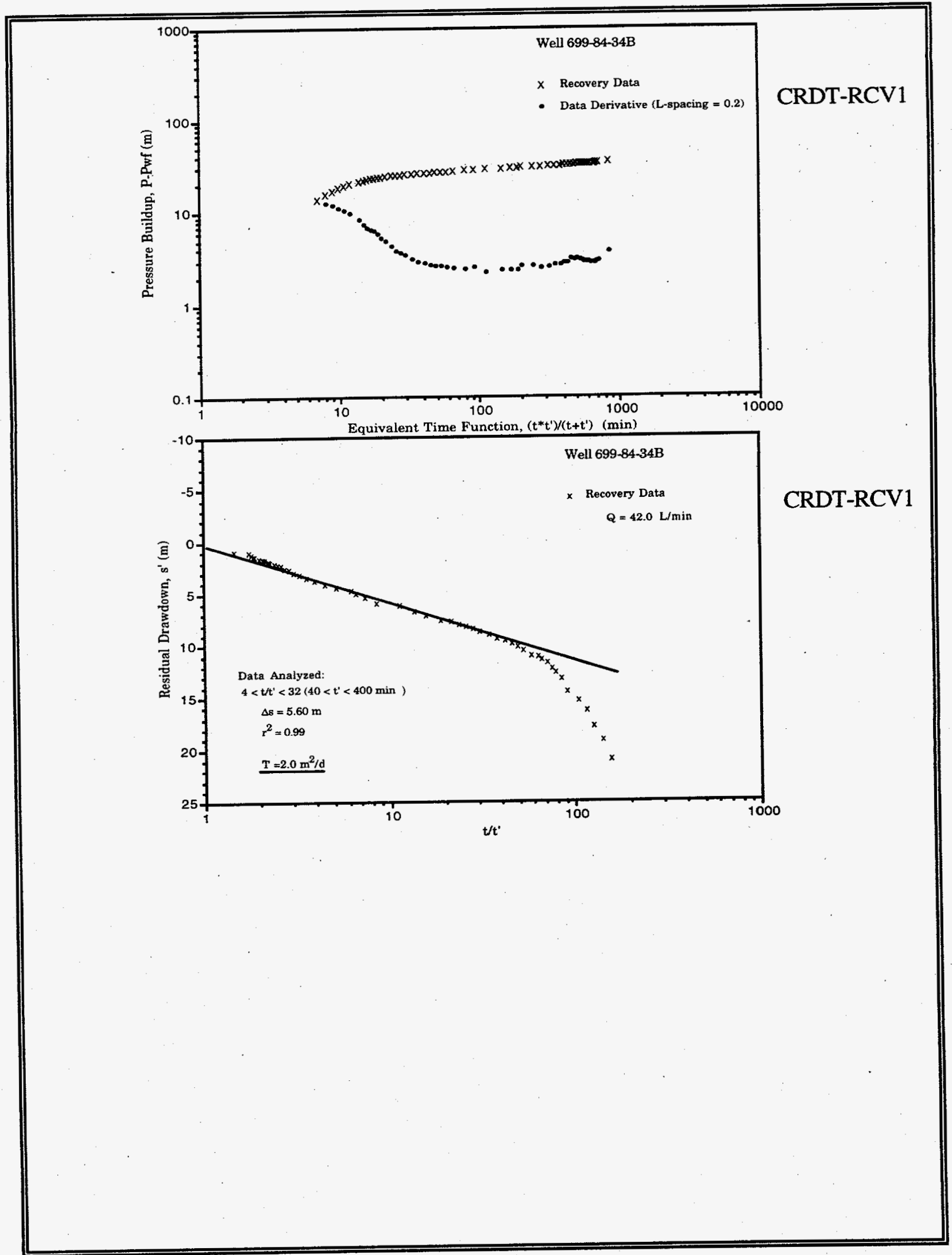




\section{Data Sources/References}

Agarwal, R. G. 1980. "A New Method to Account for Producing Time Effects when Drawdown Type Curves are Used to Analyze Pressure Buildup and Other Test Data." Presented at the 1980 Society of Petroleum Engineers Annual Technical Conference and Exhibition, Sept. 21-24, 1980, Dallas. SPE Paper 9289.

Cooper, H. H., Jr., and C. E. Jacob. 1946. "A Generalized Graphical Method for Evaluating Formation Constants and Summarizing Well-Field History." American Geophysical Union, Transactions 27(4):526-534.

Deju, R. A. 1974. The Hanford Field Testing Program. ARH-C-004, Atlantic Richfield Hanford Company, Richland, Washington.

Gephart, R. E., R. C. Arnett, R. G. Baca, L. S. Leonhart, F. A. Spane, Jr., D. A. Palumbo, and S. R. Strait. 1979. Hydrologic Studies Within the Columbia Plateau Washington: An Integration of Current Knowledge. RHO-BWI-ST-5, Rockwell Hanford Operations, Richland, Washington.

Graham, M. L., G. V. Last, and K. R. Fecht. 1984. An Assessment of Aquifer Intercommunication in the B Pond-Gable Mountain Pond Area of the Hanford Site. RHO-RE-ST-12P, Rockwell Hanford Operations, Richland, Washington.

Hantush, M. S., and C. E. Jacob. 1955. "Non-Steady Radial Flow in an Infinite Leaky Aquifer." American Geophysical Union, Transactions 36(1):95-100.

Jacob, C. E., and S. W. Lohman. 1952. "Nonsteady Flow to a Well of Constant Drawdown in an Extensive Aquifer." American Geophysical Union, Transactions 33:559-569.

Novakowski, K. S. 1990. "Analysis of Aquifer Tests Conducted in Fractured Rock: A Review of the Physical Background and the Design of a Computer Program for Generating Type Curves." Ground Water 28(1):99-105.

Ostrowski, L. P., and M. B. Kloska. 1989. "Use of Pressure Derivatives in Analysis of Slug Test or DST Flow Period Data." Society of Petroleum Engineers, SPE Paper 18595.

Spane, F. A., Jr. 1981. Hydrogeologic Properties and Hydrochemistry for the Levey Interbed at Well 699-S11-E12A. RHO-BWI-LD-27, Rockwell Hanford Operations, Richland, Washington.

Spane, F. A., Jr. 1992. Hydraulic Test Results for Savage Island Wells 699-32-22B, 699-42-E9A, and 699-42-E9B. PNL-8173, Pacific Northwest Laboratory, Richland, Washington.

Spane, F. A., Jr., M. D. Howland, and S. R. Strait. 1980. Hydrogeologic Properties and Ground-Water Chemistry of the Rattlesnake Ridge Interbed at Well 699-25-80 (DB-14), Hanford Site. RHO-LD-67, Rockwell Hanford Operations, Richland, Washington. 
Strait, S. R., and W. R. Brown. 1983. Hydrologic Test Results for the Rattlesnake Ridge Interbed and Pomona Basalt Flowtop at Borehole DB-15. SD-BWI-TI-130, Rockwell Hanford Operations, Richland, Washington.

Strait, S. R., and B. A. Moore. 1982. Geohydrology of the Rattlesnake Ridge Interbed in the Gable Mountain Pond Area. RHO-ST-38, Rockwell Hanford Operations, Richland, Washington.

Swanson, L. C. 1992. Aquifer Test Report for Wells 699-49-57B, 699-52-54, 699-52-57, 699-53-55C, 200-BP-1 Operable Unit. WHC-SD-ER-TD-001, Westinghouse Hanford Company, Richland, Washington.

Theis, C. V. 1935. "The Relationship Between the Lowering of the Piezometric Surface and the Rate and Duration of Discharge of a Well Using Ground-Water Storage. American Geophysical Union, Transactions, pt. 2, pp. 519-524; reprinted in Society of Petroleum Engineers, 1980 "Pressure Transient Testing Methods." SPE Reprint Series, 14:27-32. 


\section{Distribution}

No. of

Copies

OFFSITE

2 DOE/Office of Scientific and Technical Information
A. Aldrich
U.S. Bureau of Land Management
Spokane District Office
1103 North Fancher
Spokane, WA 99212-1275

J. Atwood

Washington State Department of Ecology

P.O. Box 1386

Richland, WA 99352

B. Blake

133 1st Avenue North

Minneapolis, MN 55401

J. Blanchard

U.S. Bureau of Reclamation

P.O. Box 815

Ephrata, WA 98823

L. Block

U.S. Fish and Wildlife Service

P.O. Box 1157

Moses Lake, WA 98837

2 J. Brodeur

R. Jim

Yakama Indian Nation

Environmental Restoration Waste/

Management

P.O. Box 151

Toppenish, WA 98948
No. of

Copies

R. Buck, Jr.

Wanapum Indian Band

P.O. Box 878

Ephrata, WA 98823

R. A. Danielson

Washington State Department of Health

2 South 45th Ave.

Yakima, WA 98908

G. De Bruler

Columbia River United

P.O. Box 667

Bingen, WA 98605

B. Drost

U.S. Geological Survey

1201 Pacific Avenue, Suite 600

Tacoma, WA 98402

J. Erickson

Washington State Department of

Health

Division of Radiation

Protection

Airdustrial Center

Building 5, M.S. L-13

Olympia, WA 98503

2 T. Gilmore

J. R. Wilkerson

Environmental Planning/

Rights Protection

Confederated Tribes of the

Umatilla Indian Reservation

P.O. Box 638

Pendleton, OR 97801 
No. of

\section{Copies}

2

D. Powaukee

S. Harris

Environmental Restoration/

Waste Management

Nez Perce Tribe

P.O. Box 365

Lapwai, ID 83540-0365

3 D. Jansen

C. Cline

K. Kowalic

Washington State Department of Ecology

99 South Sound Center

M.S. 7600

Olympia, WA $98504-7600$

J. Leier

U.S. Army Corps of Engineers

Walla Walla District

Building 602, City-County Airport

Walla Walla, WA 99362-9265

R. Patt

Oregon State Department of

Water Resources

3850 Portland Road

Salem, OR 97310

South Columbia Basin Irrigation

District

402 W. Lewis Street

Pasco, WA 99301

\section{ONSITE}

\section{DOE Richland Operations Office}

G. M. Bell

A5-52

R. F. Brich

A5-19

M. J. Furman

R3-81

E. D. Goller

A5-19

J. D. Goodenough

J. B. Hall
No. of

Copies

R. D. Hildebrand

A5-55

R. G. Holt

R. G. McLeod

P. M. Pak

A5-15

A5-19

A5-19

R. K. Stewart

A5-19

K. M. Thompson

A5-19

\section{Bechtel Hanford}

K. R. Fecht

H4-80

B. H. Ford

H6-07

L. C. Hulstrom

H6-01

G. L. Kasza

H6-04

A. J. Knepp

M. J. Lauterbach

H4-80

H6-01

K. D. Lyso

H4-79

D. A. Myers

D. L. Parker

J. W. Roberts

L. C. Swanson

J. S. Treadwell

S. J. Trent

D. C. Weekes

S. R. Weil

H4-79

H6-02

H6-03

H6-03

H4-79

H4-80

H6-07

H4-80

3 CH2M-Hill

J. V. Borghese H6-04

R. L. Jackson H6-04

R. E. Peterson H6-05

3 U.S. Army Corps of Engineers

W. L. Greenwald

A5-20

M. P. Johansen

A5-19

W. D. Perro

A5-19

3 U.S. Environmental Protection Agency

P. R. Beaver

B5-01

L. E. Gadbois

B5-01

D. R. Sherwood

B5-01 
No. of

Copies

18 Westinghouse Hanford

H6-01

M. R. Adams

D. B. Barnett

L. C. Brown

J. W. Cammann

L. B. Collard

L. P. Diediker

M. G. Gardner

E. M. Greager

M. J. Hartman

D. G. Horton

V. G. Johnson

A. G. Law

R. B. Mercer

J. A. Rawlins

S. P. Reidel

J. A. Serkowski

J. S. Schmid

Public Reading Room

46 Pacific Northwest Laboratory

M. P. Bergeron

R. W. Bryce

M. A. Chamness

C. R. Cole

L. A. Doremus

P. E. Dresel

J. C. Evans
H6-06

H6-20

H6-06

H6-30

T1-30

N3-06

H6-20

H6-06

H6-06

H6-06

H6-06

H6-06

H0-36

H6-06

H6-06

H6-06

K6-77

K6-96

K6-84

K6-96

K6-84

K6-96

K6-96
No. of

Copies

M. D. Freshley

K6-77

R. E. Gephart

K1-22

T. J Gilmore

K6-84

S. H. Hall

R. E. Jaquish

K7-54

B1-34

G. V. Last

P. E. Long

S. P. Luttrell

K6-84

K6-84

K6-96

J. P. McDonald

K6-96

Q. C. MacDonald

K6-96

K6-96

D. R. Newcomer

K6-96

K6-96

R. M. Smith

F. A. Spane, Jr. (10)

K6-96

K6-84

S. S. Teel

P. D. Thorne

K6-96

V. R. Vermeul (5)

K6-96

W. D. Webber

K6-96

S. K. Wurstner

K6-77

Publishing Coordination

Technical Report Files (5)

\section{Routing}

R. M. Ecker

M. J. Graham

P. M. Irving

S. A. Rawson

P. C. Hays/

B. V. Johnston (last)
SEQUIM

K6-78.

K6-98

K6-81

K6-86 